\title{
SPECTROPHOTOMETRIC METHODS FOR THE DETERMINATION OF COBALT: A REVIEW
}

\author{
R. Bhatnagar, I.R. Bishnoi \\ and D.N. Purohit \\ Department of Chemistry \\ M.L. Sukhadia University \\ Udaipur, India
}

CONTENTS

Page

REVIEW 1

REFERENCES 105

Work done on the spectrophotometric determination of cobalt since 1975 is reviewed and presented in tabular form in the following pages. The available information is presented in five columns, viz. name of the reagent, $\lambda \max$ or working wave-length, $\mathrm{pH}$, remarks and references. Under "remarks" the procedure, composition of the complex, sensitivity, interference studies, etc., are described in a condensed form. 


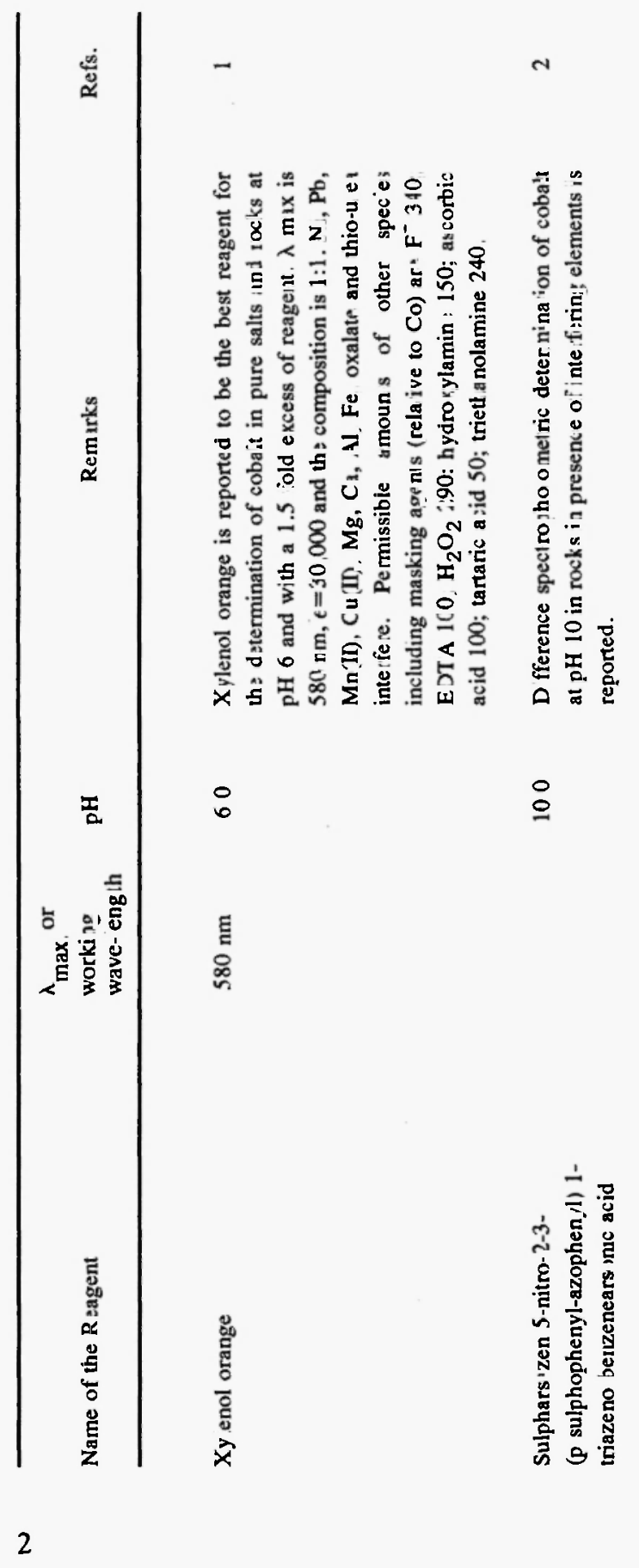




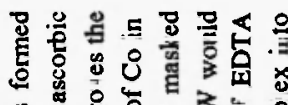

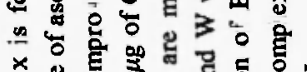

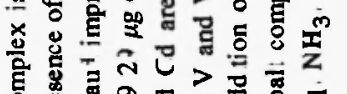

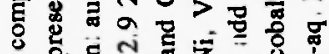
等 75
0

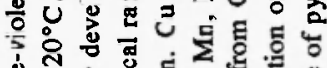

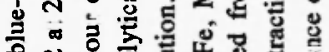

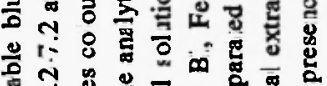
商

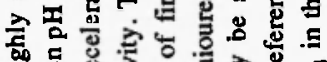

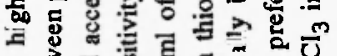

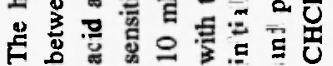
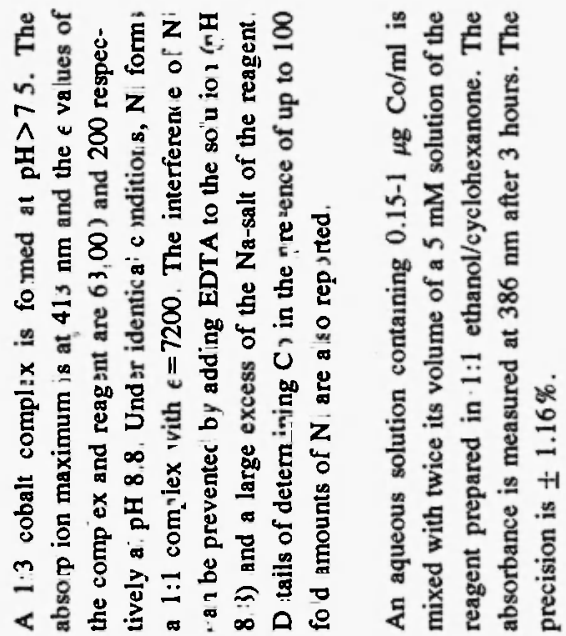

iั

$\underset{\infty}{\infty}$

焉

$\stackrel{\text { 具 }}{?}$

$E$
0

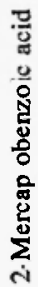
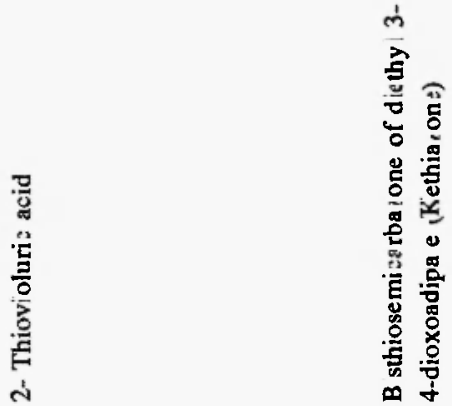


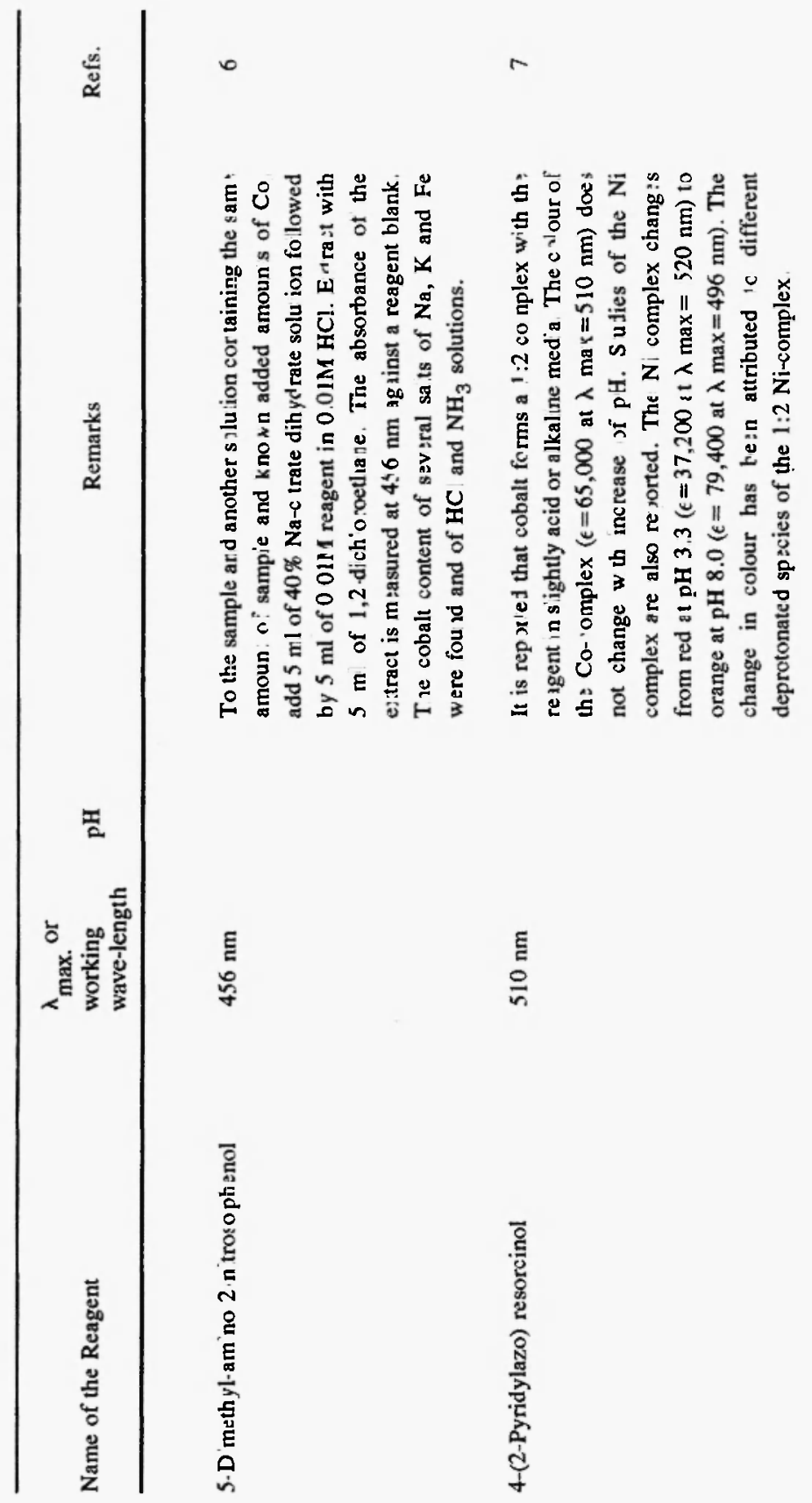




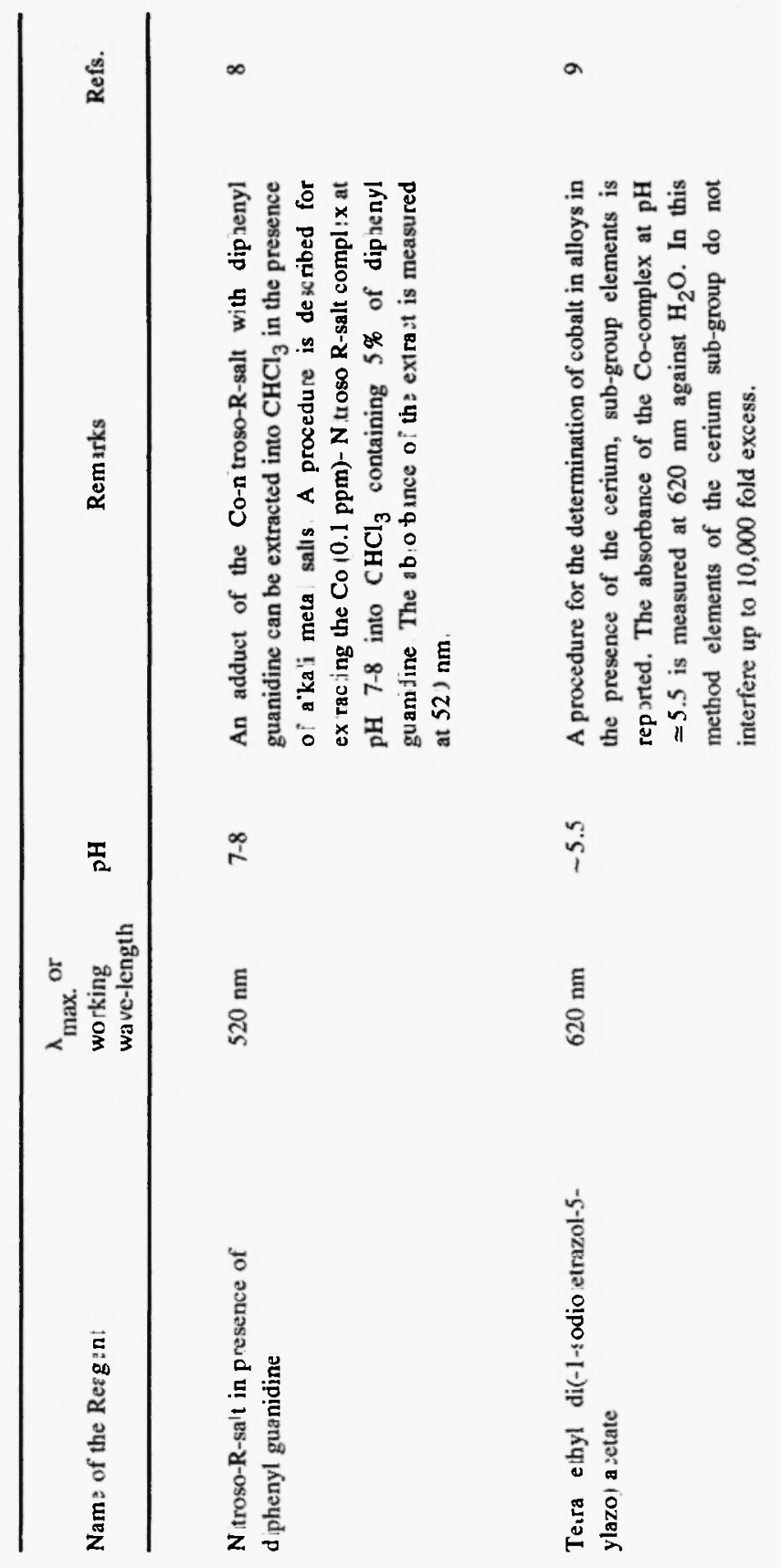




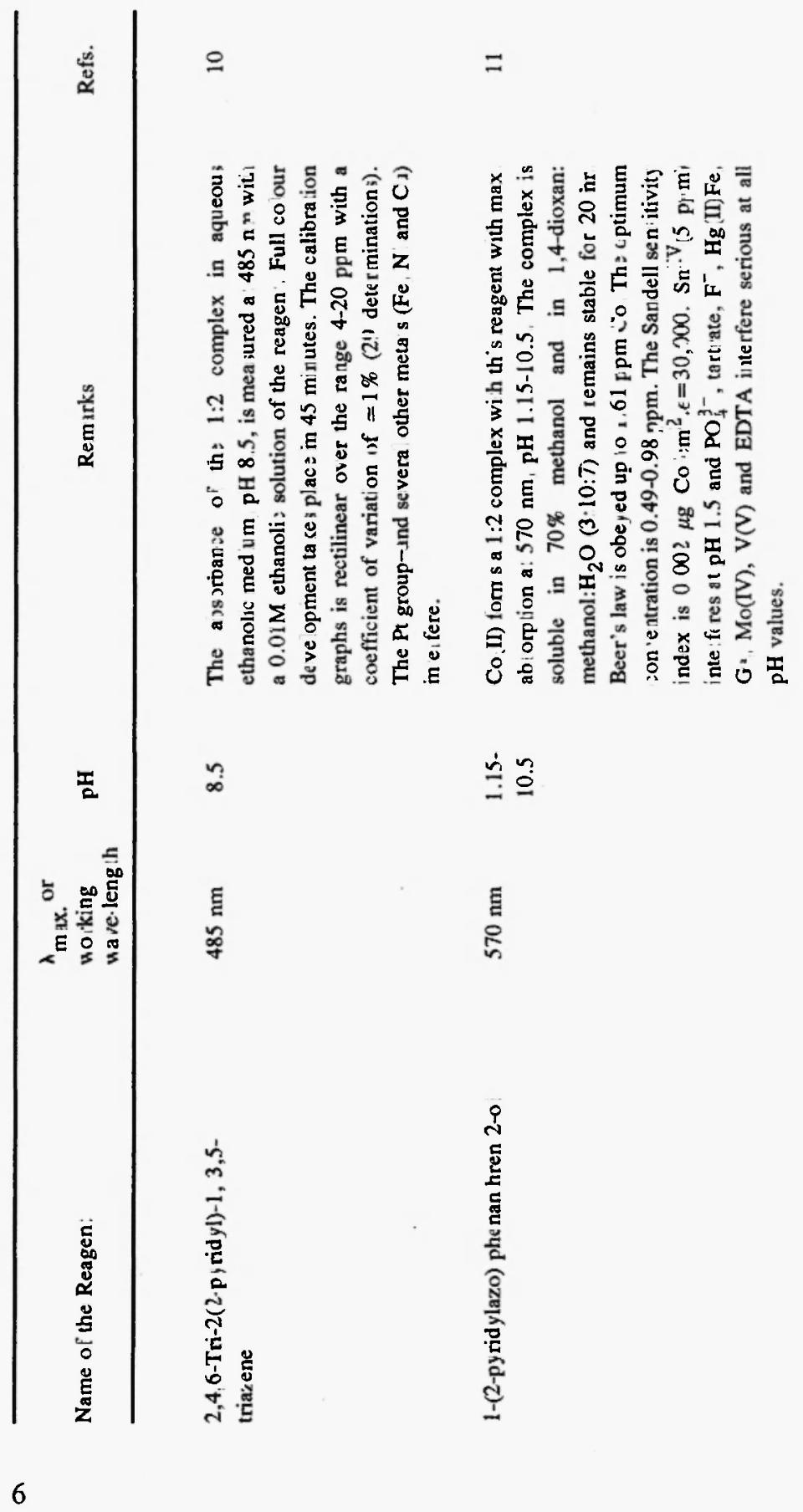




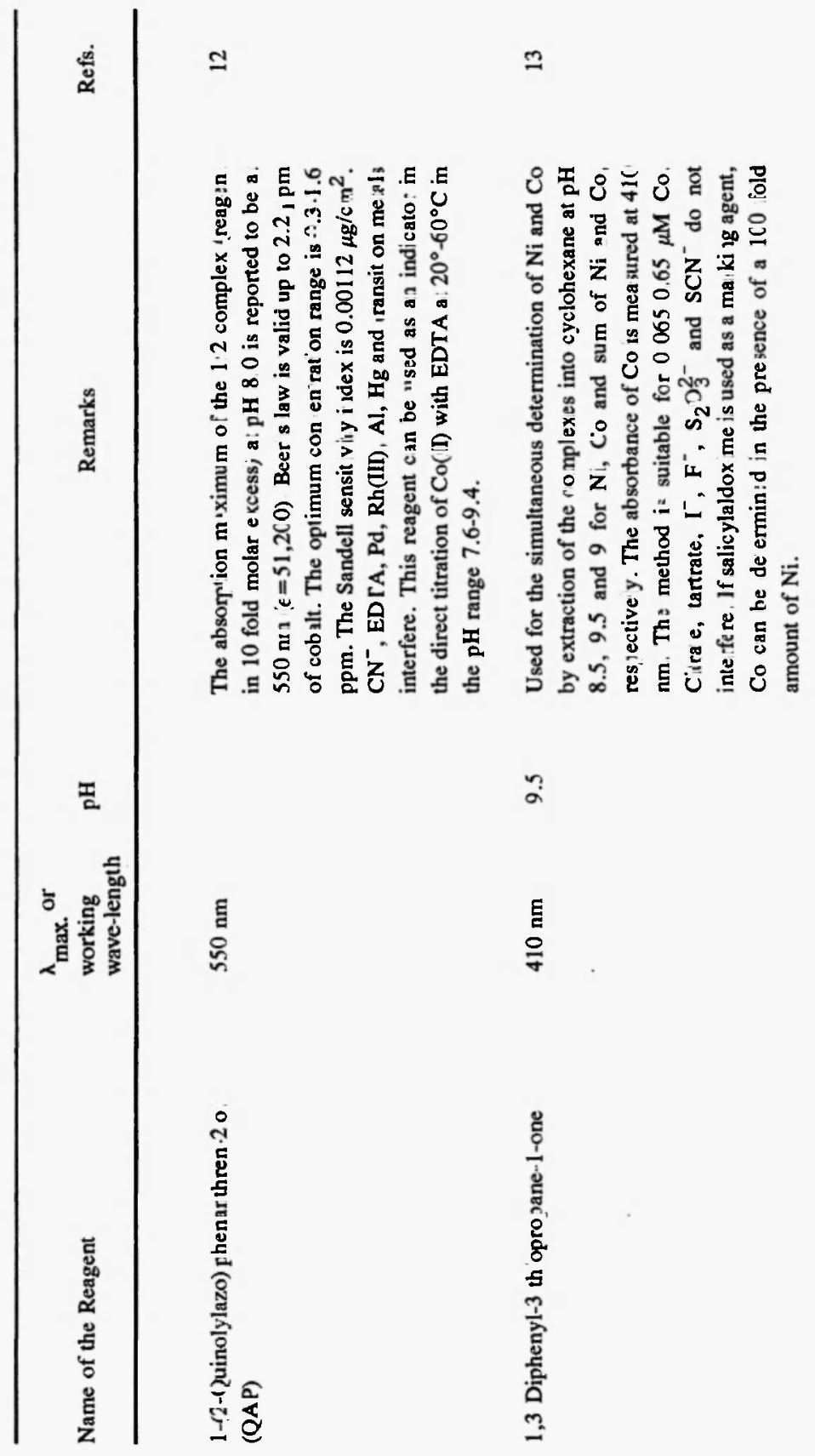




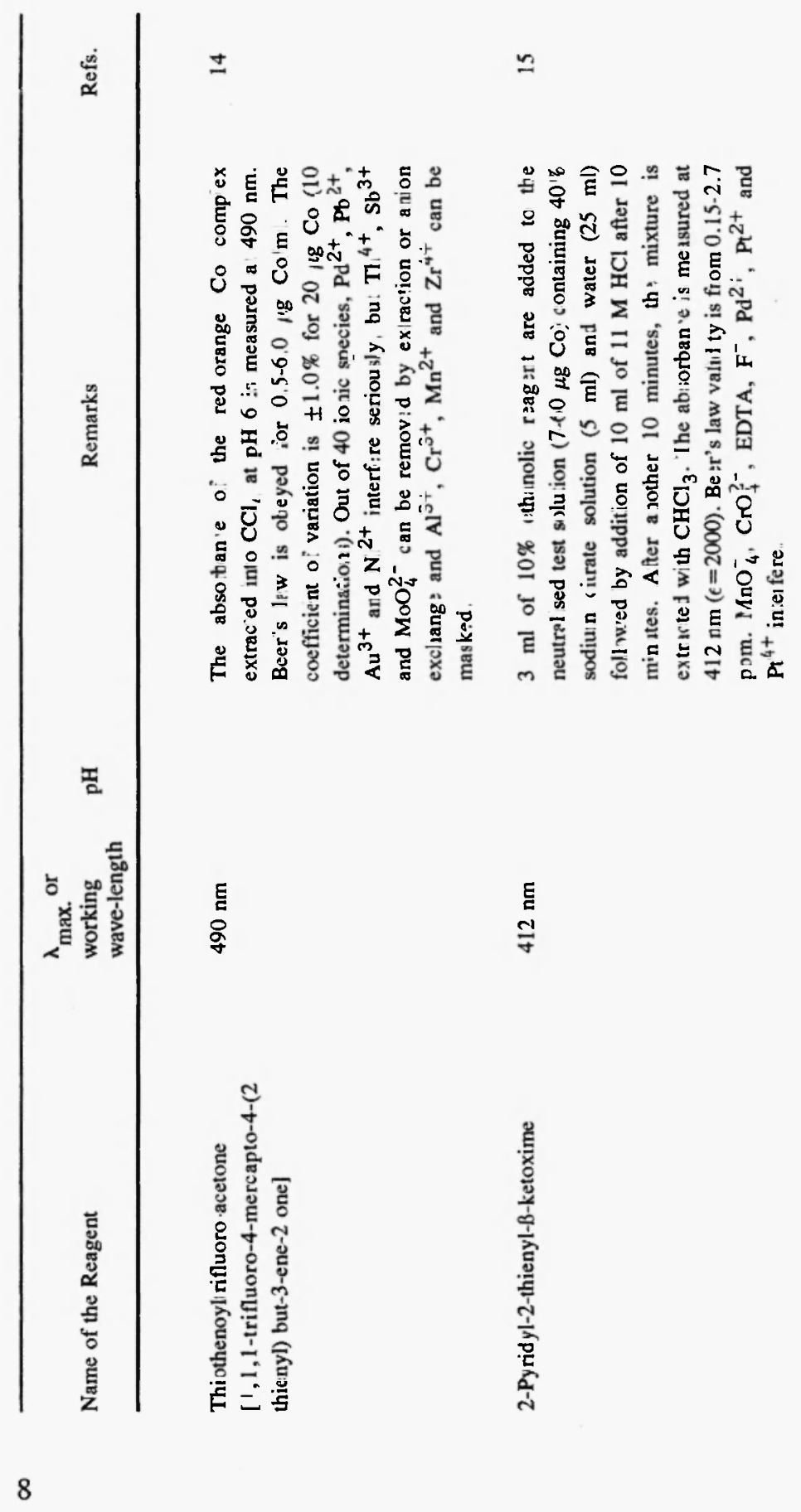




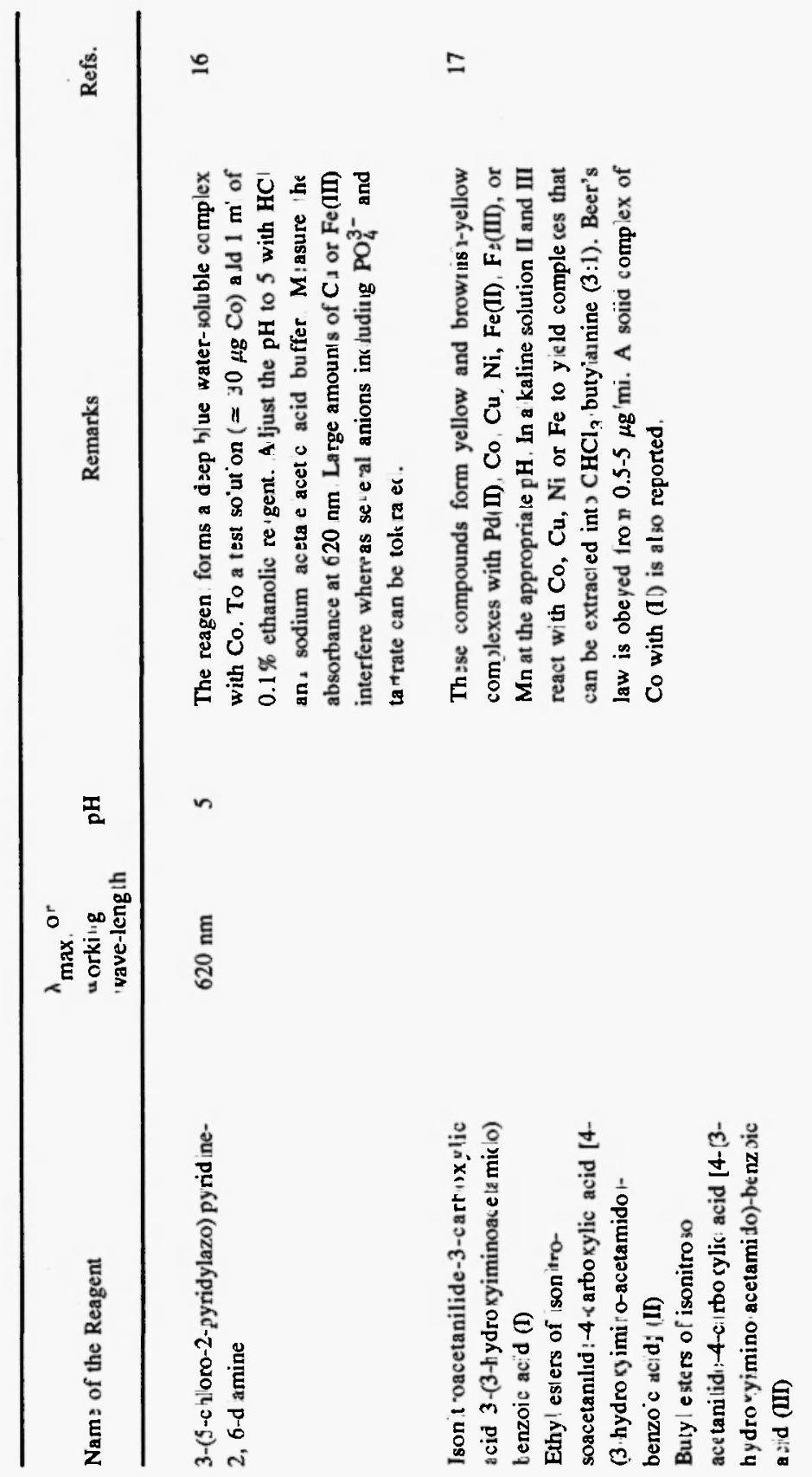




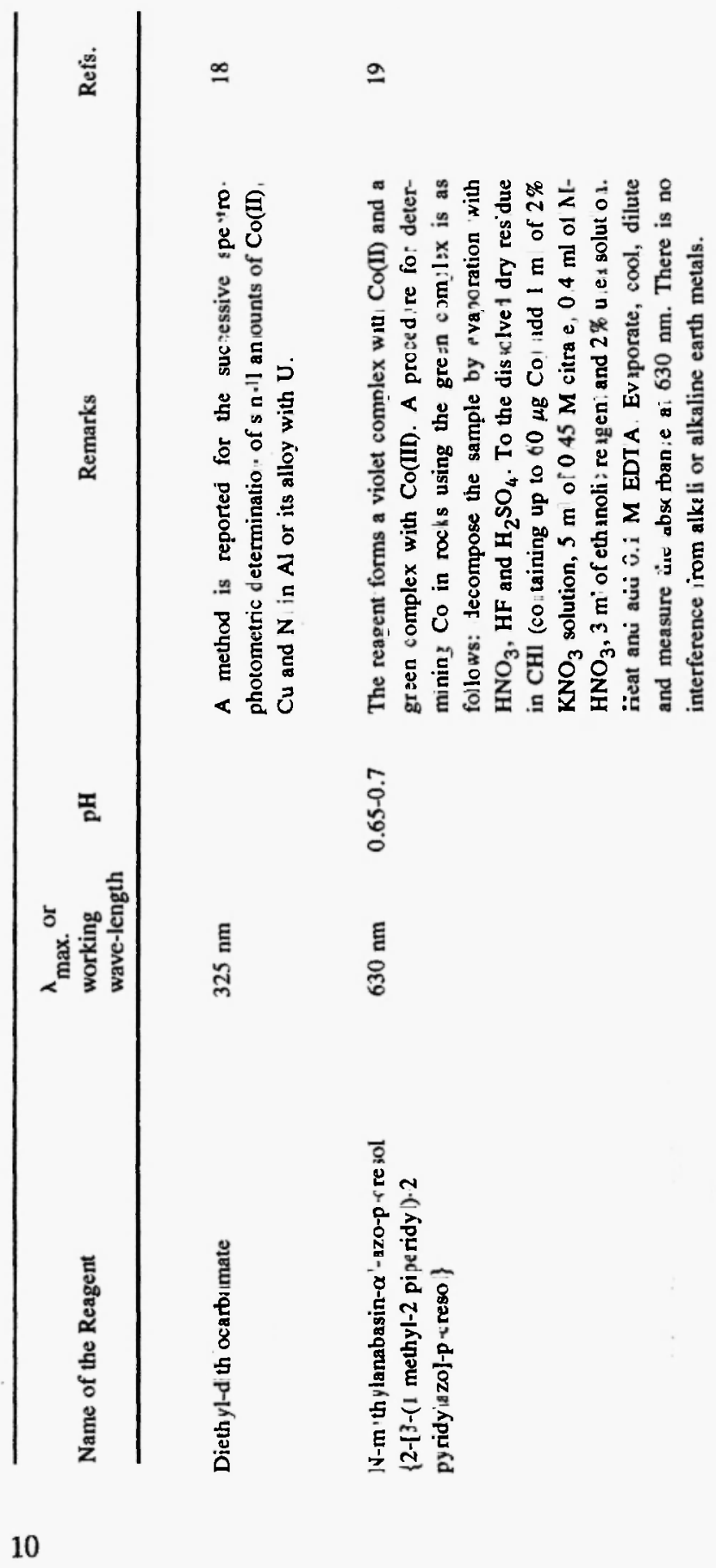




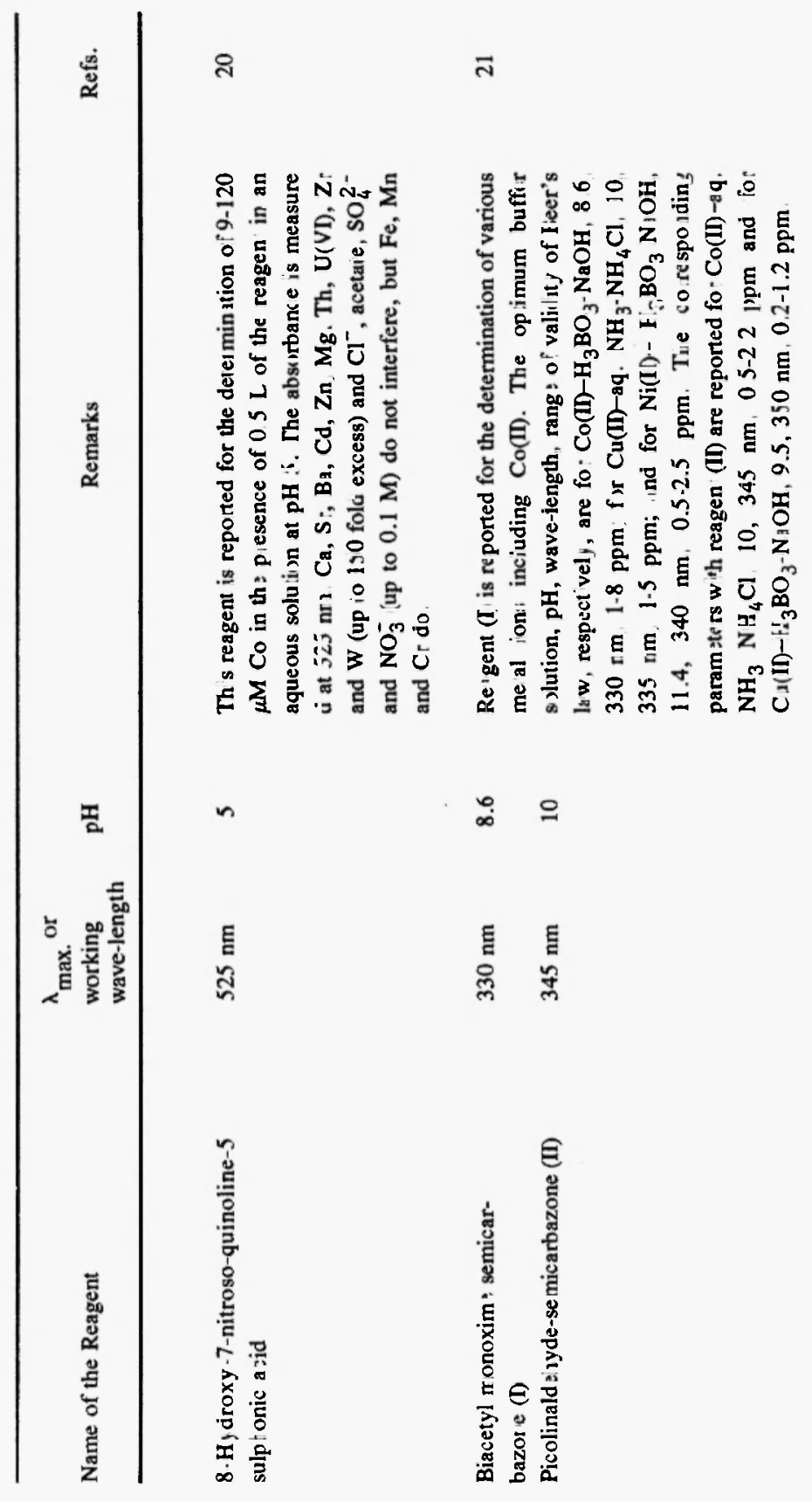




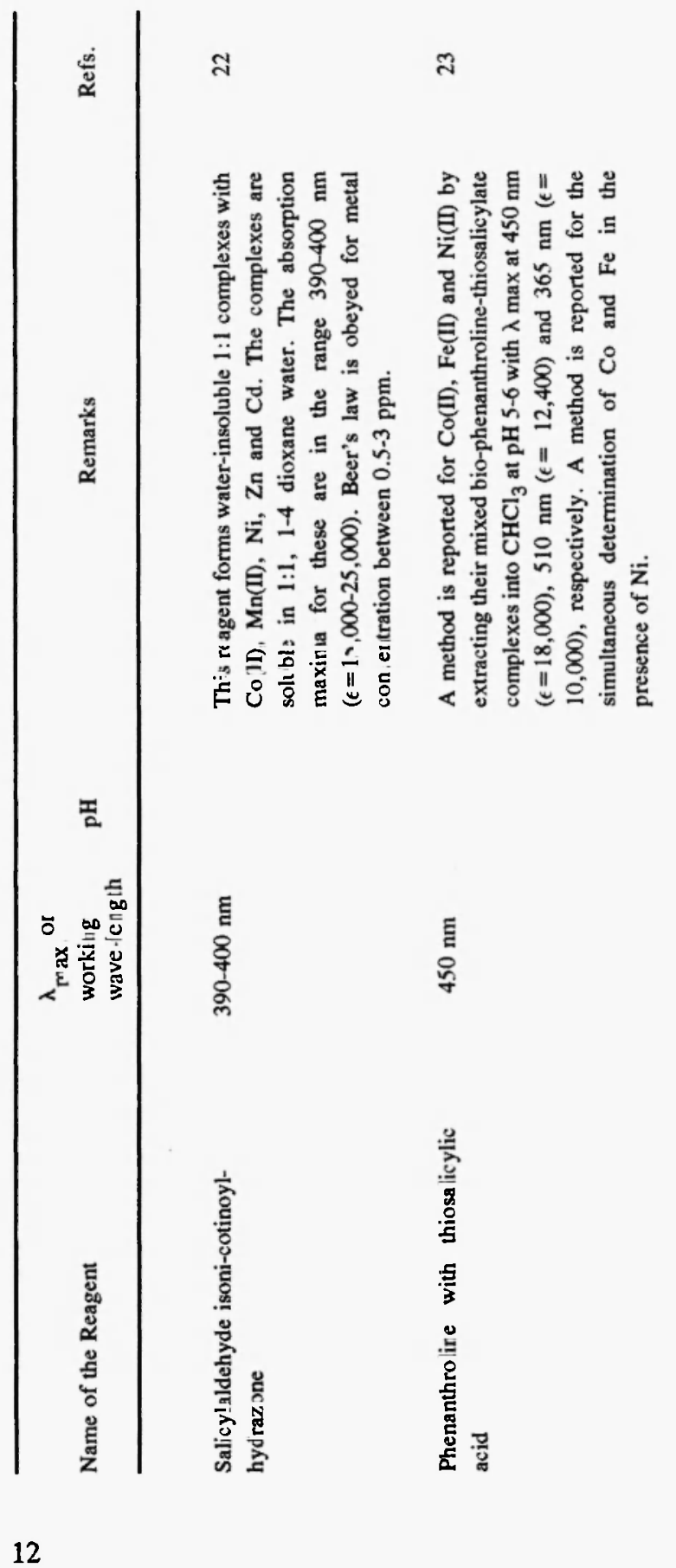




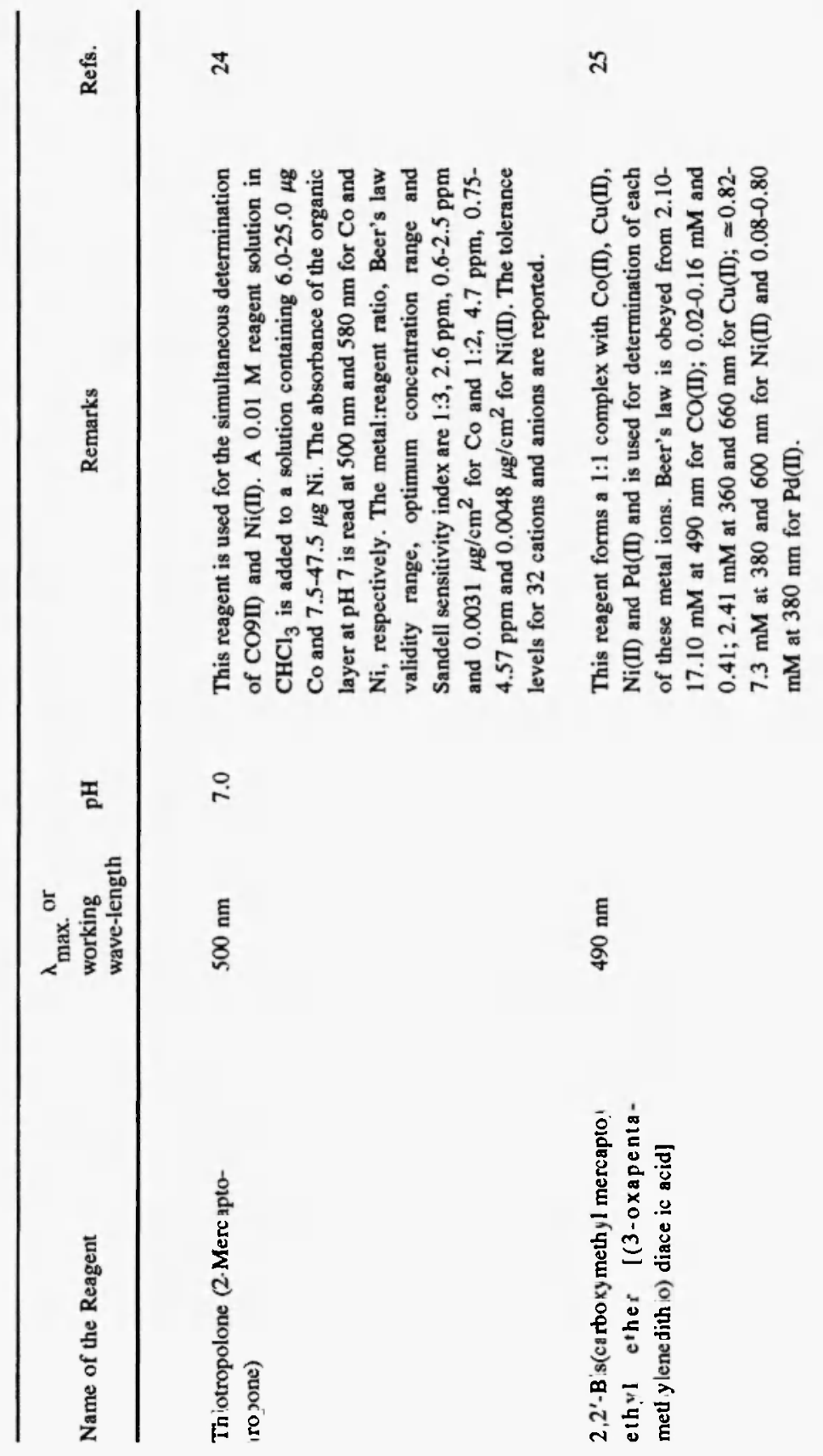




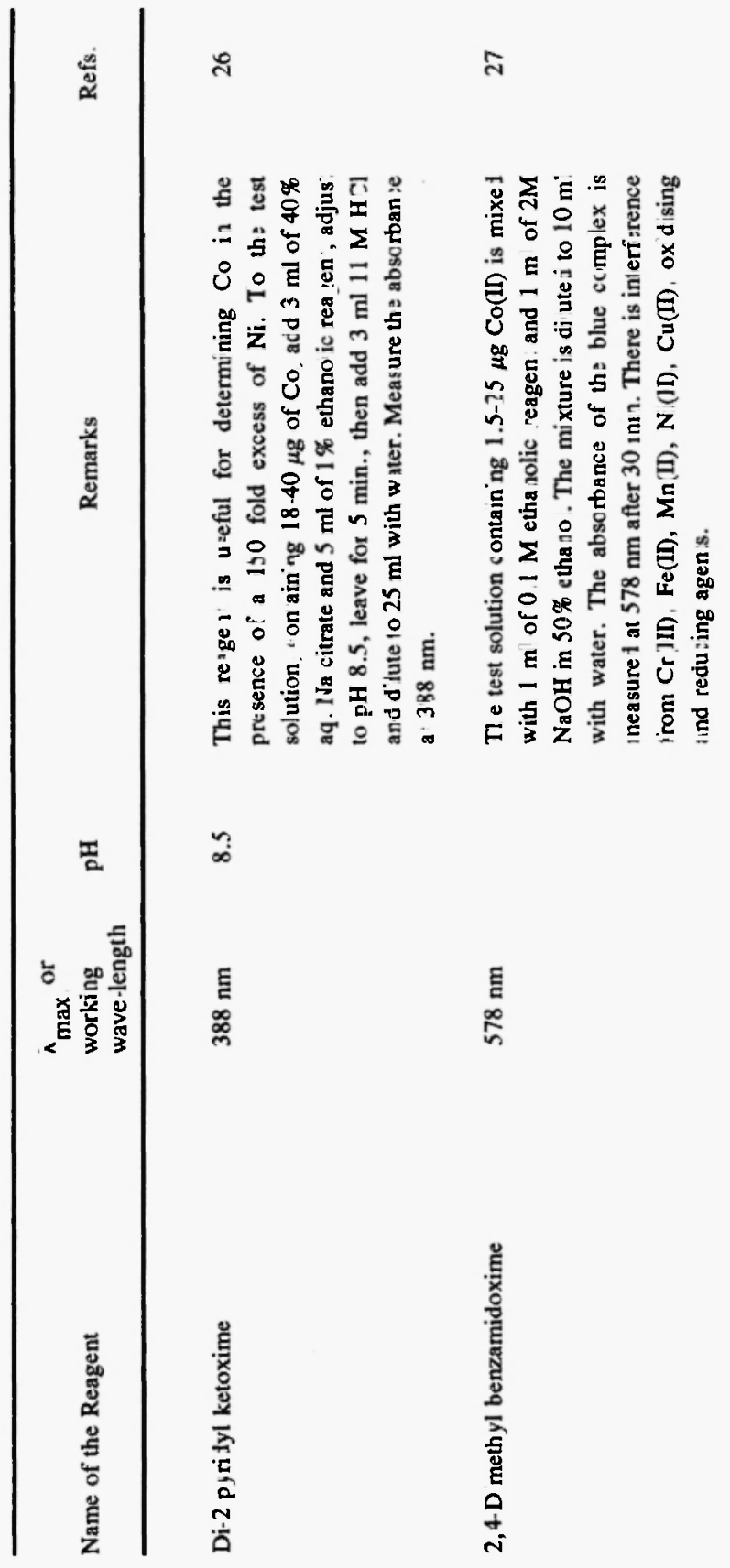




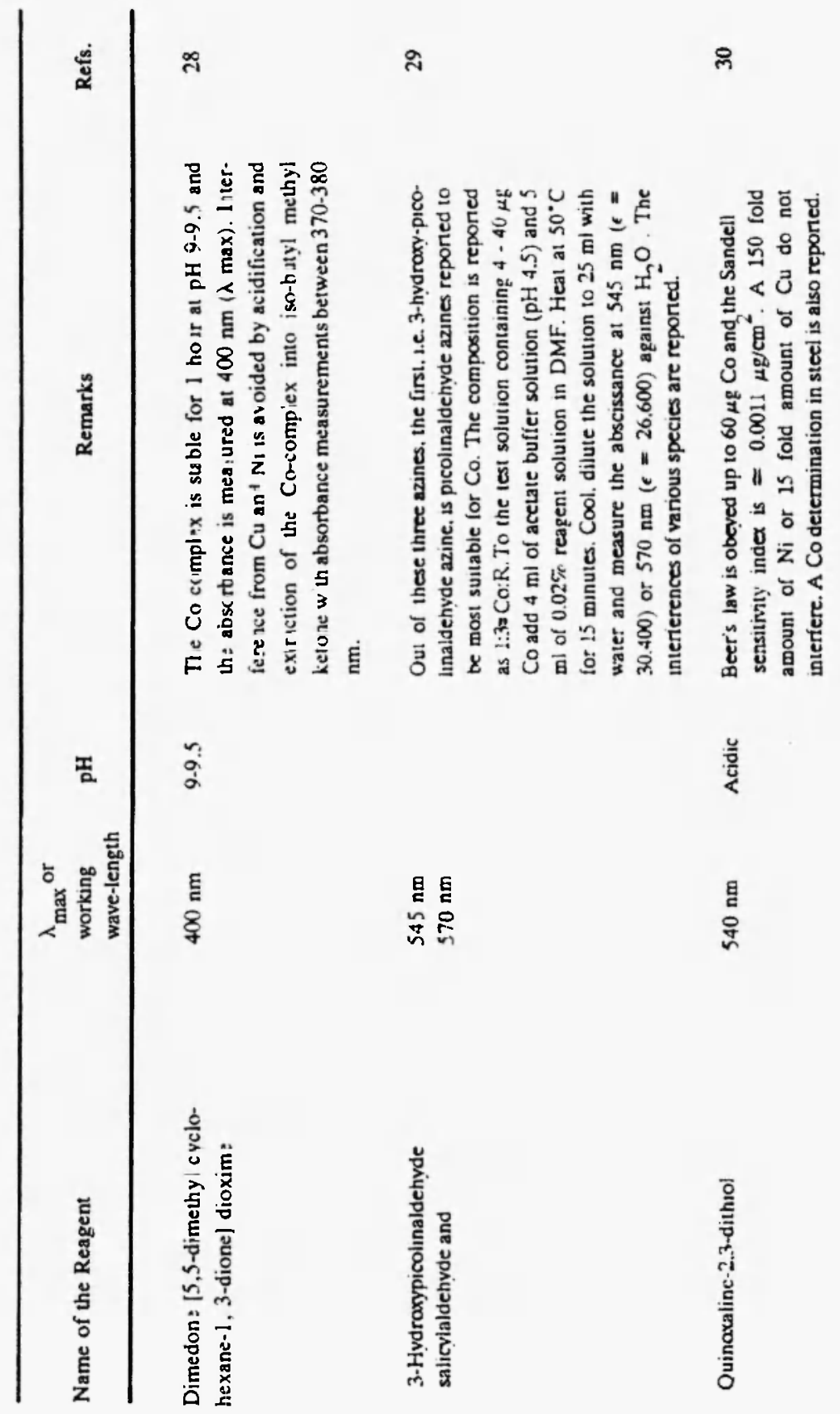




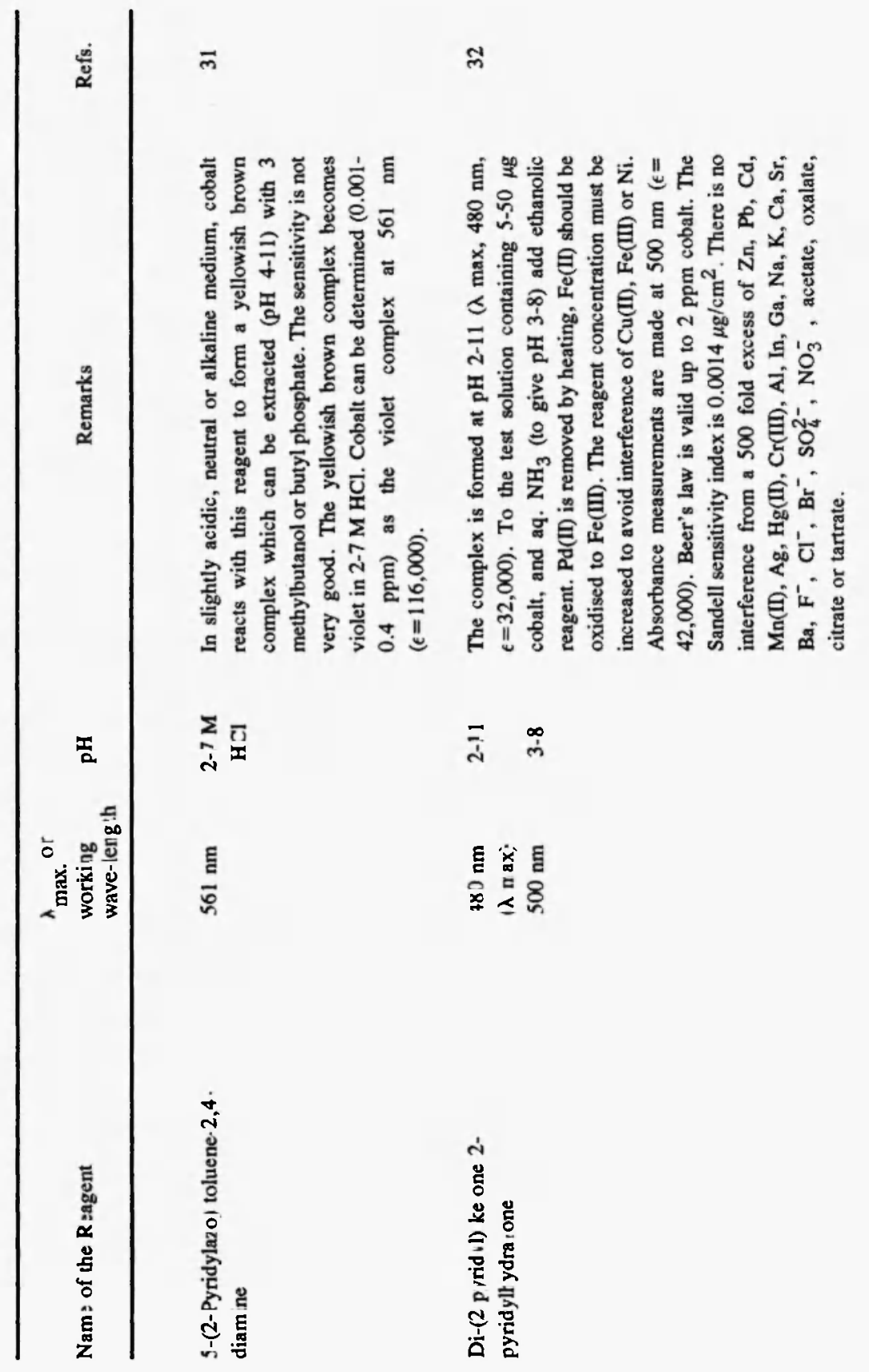




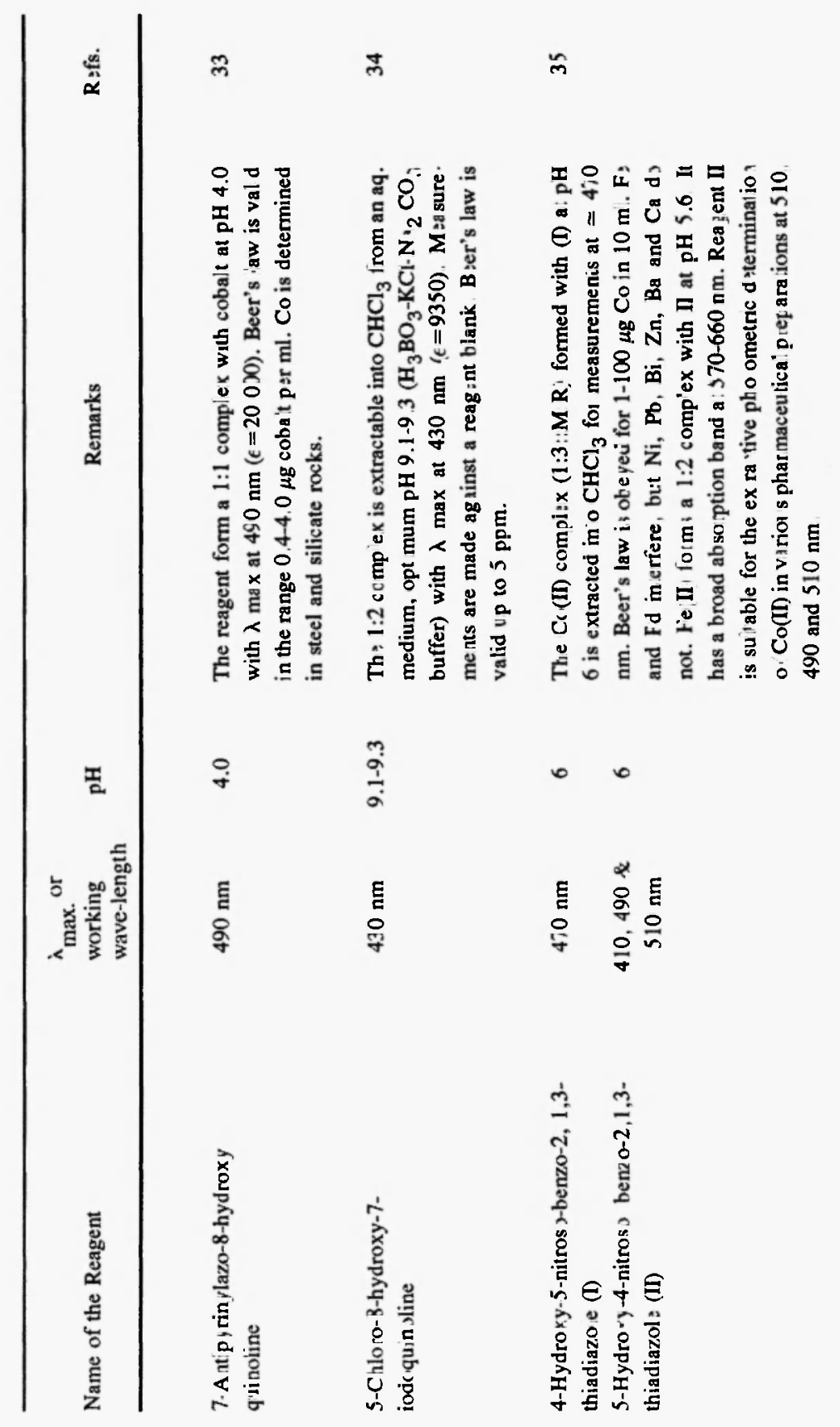




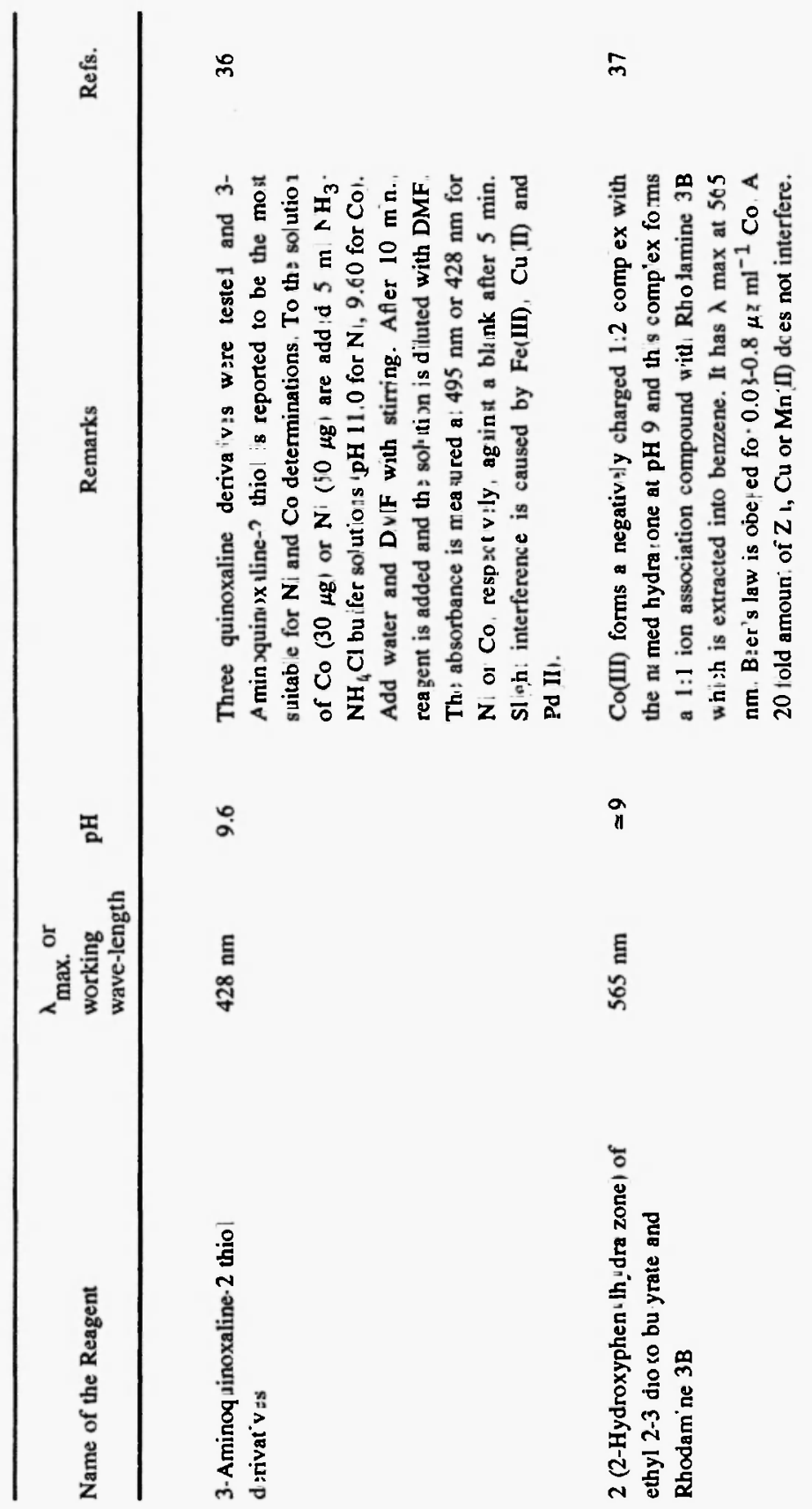




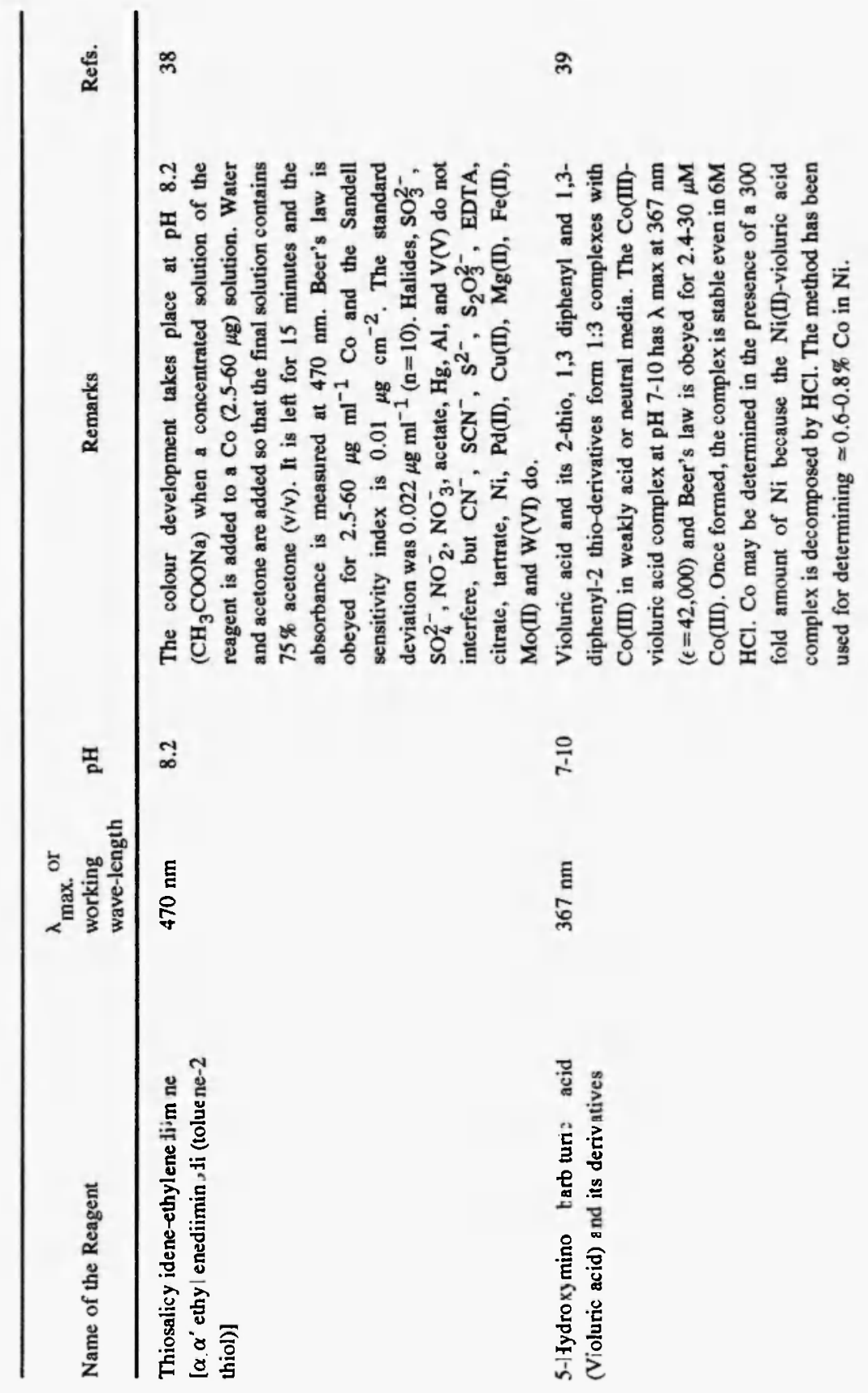




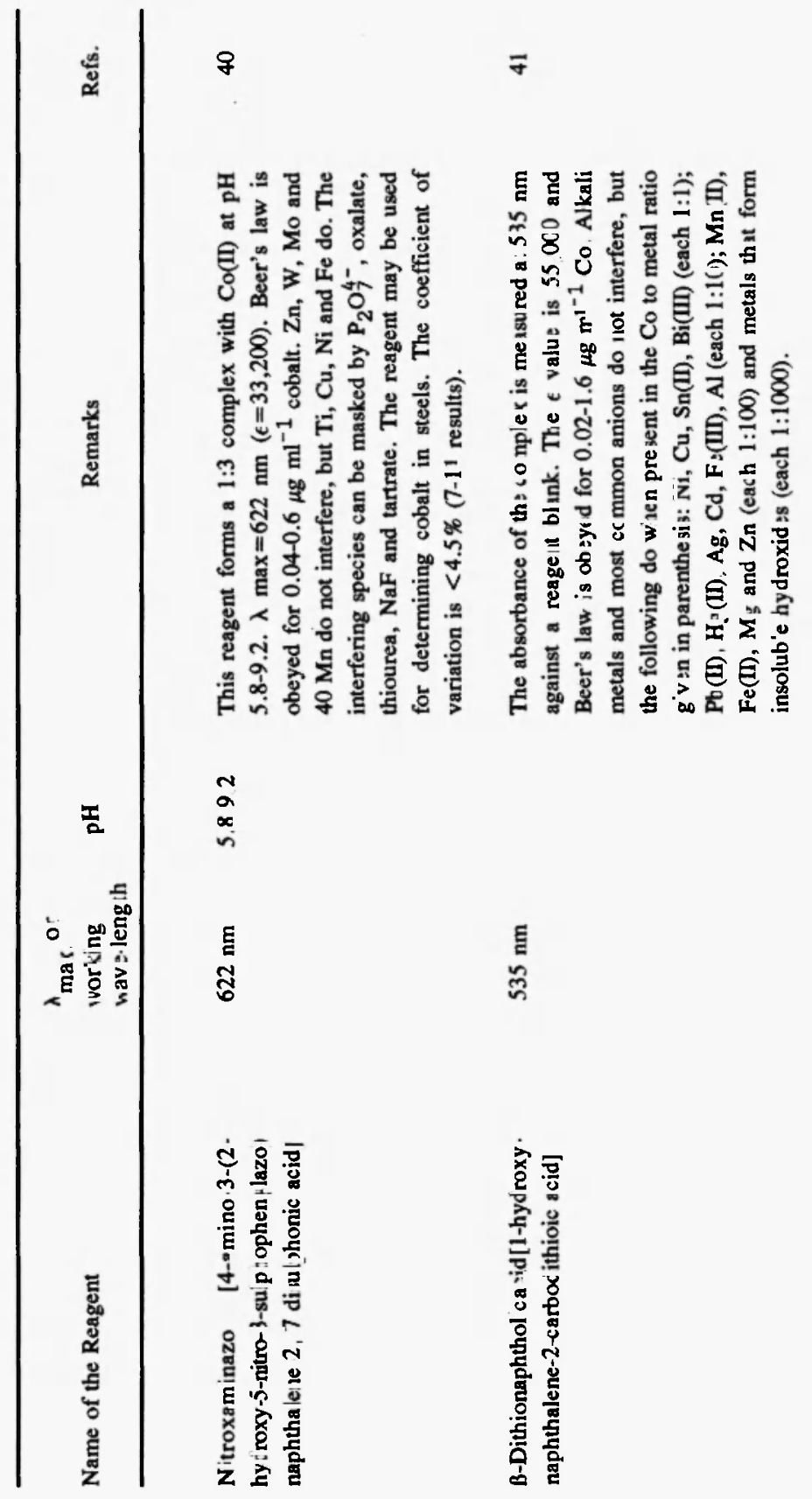




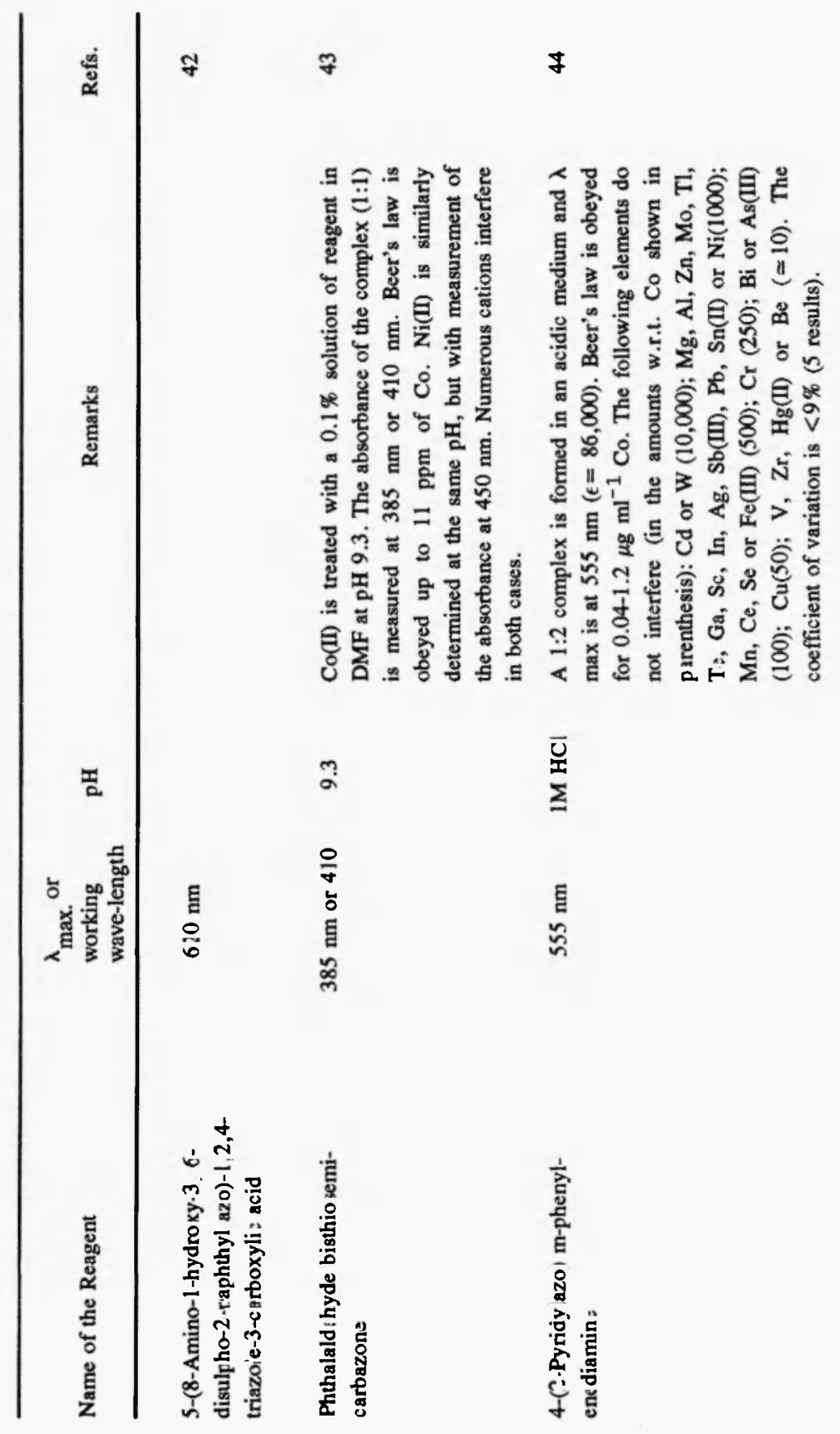




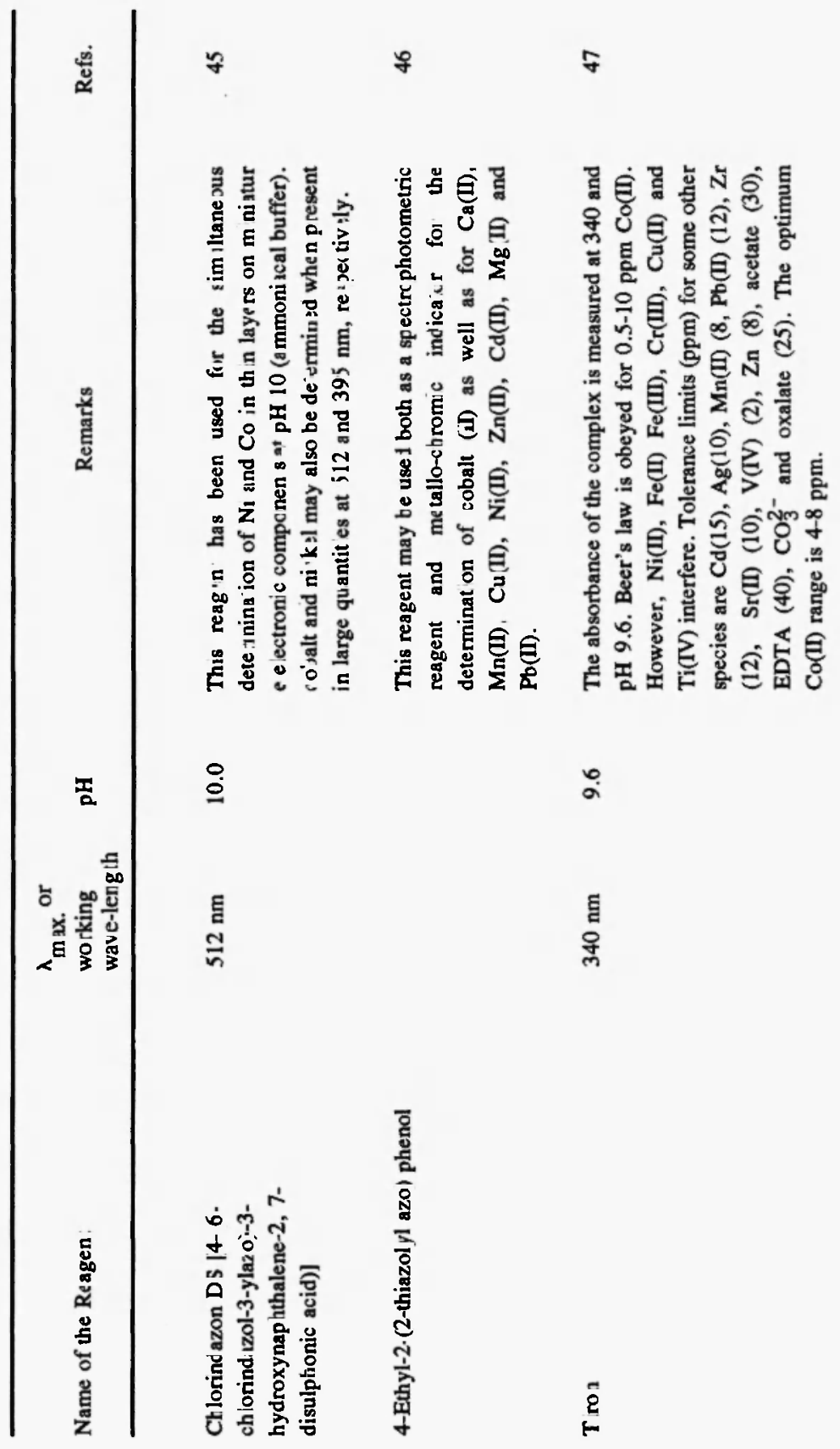




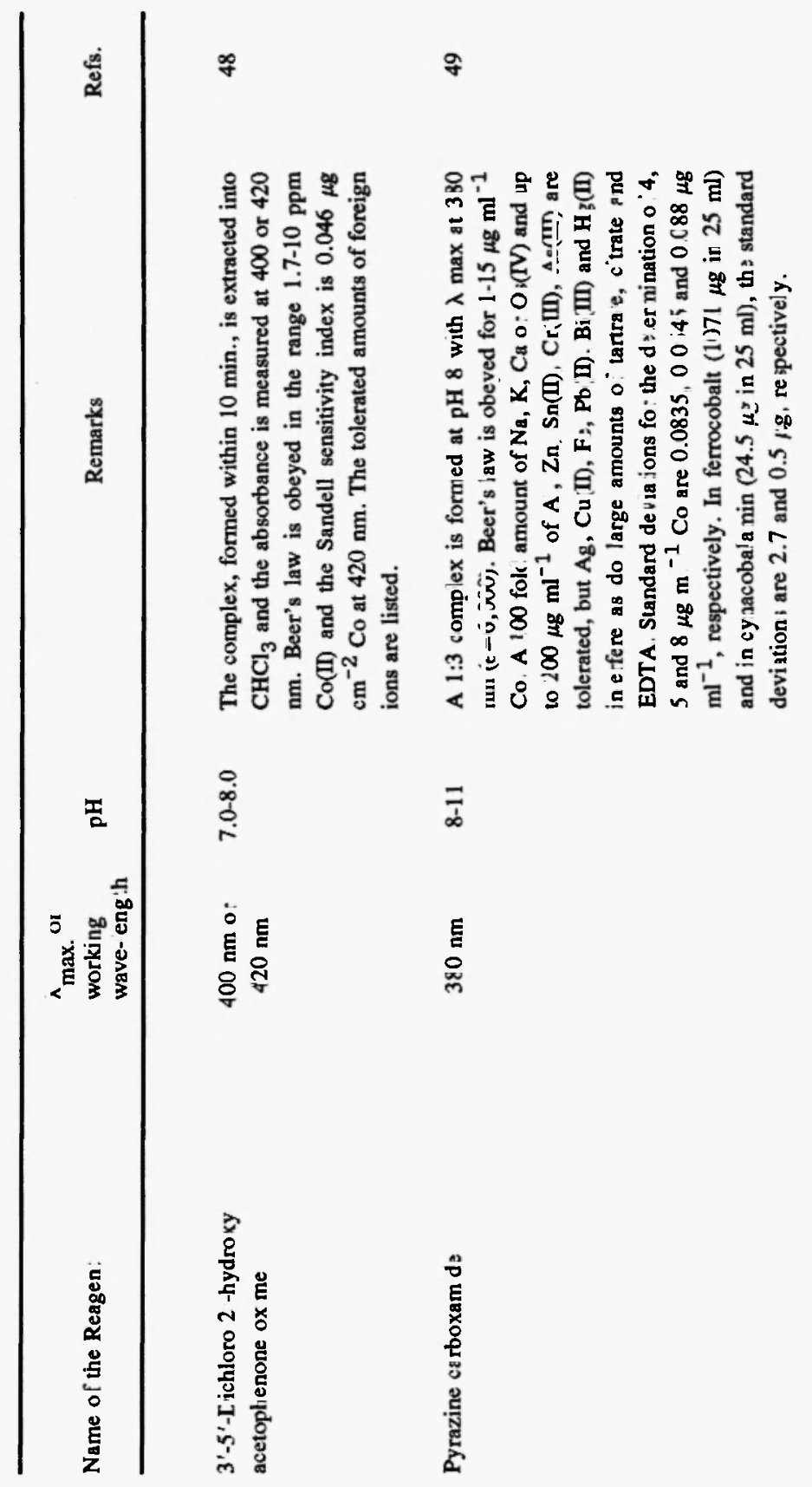




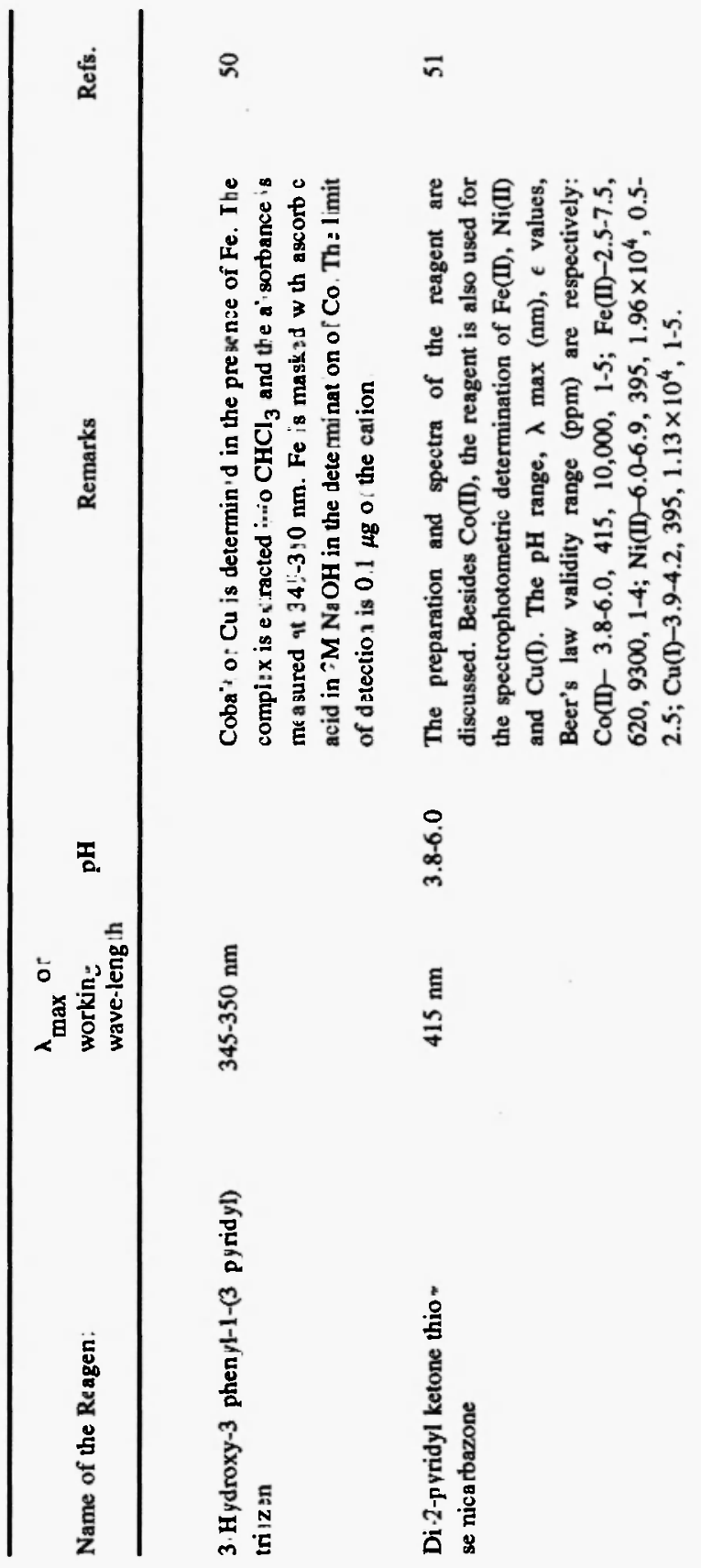




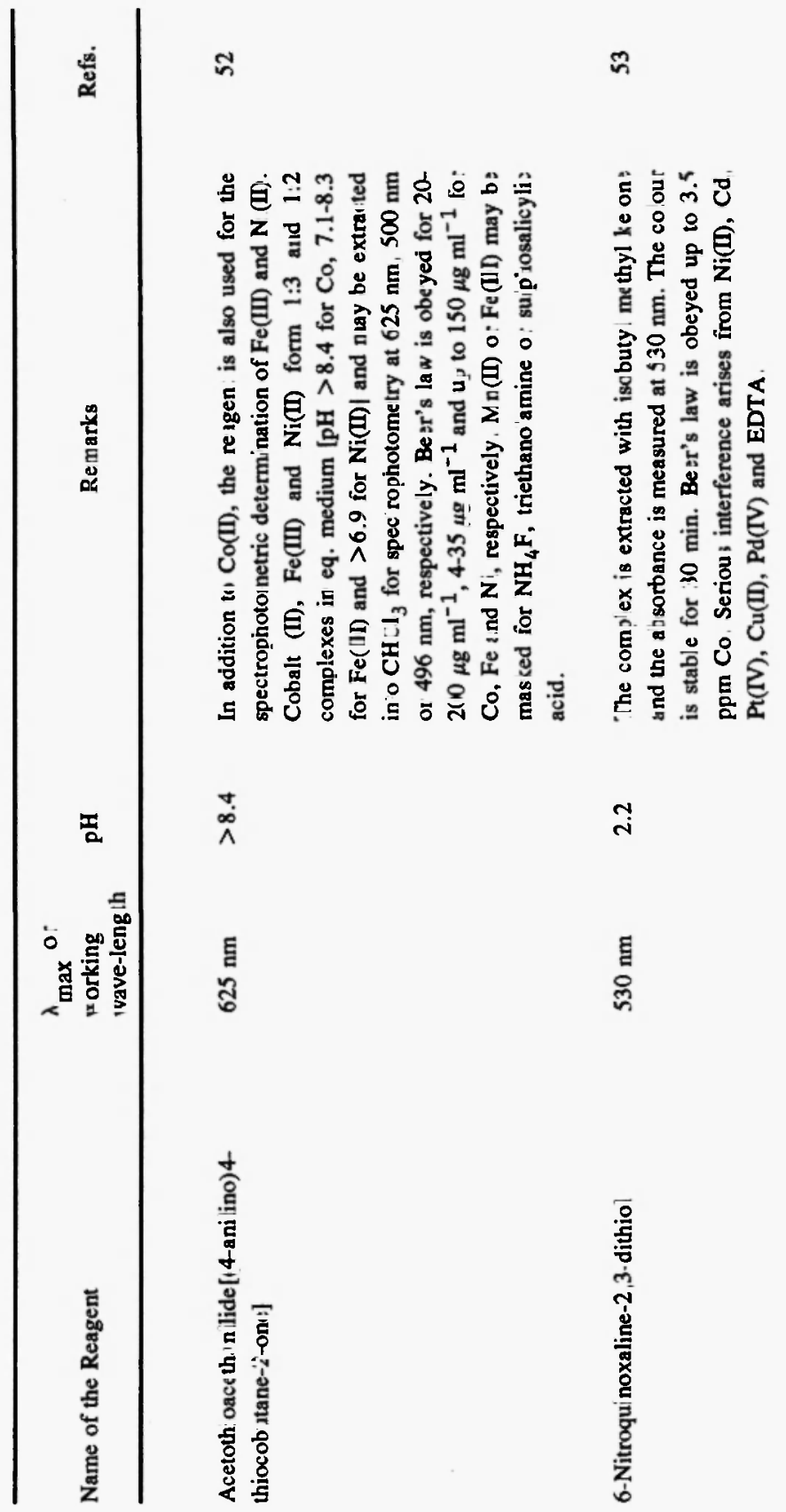




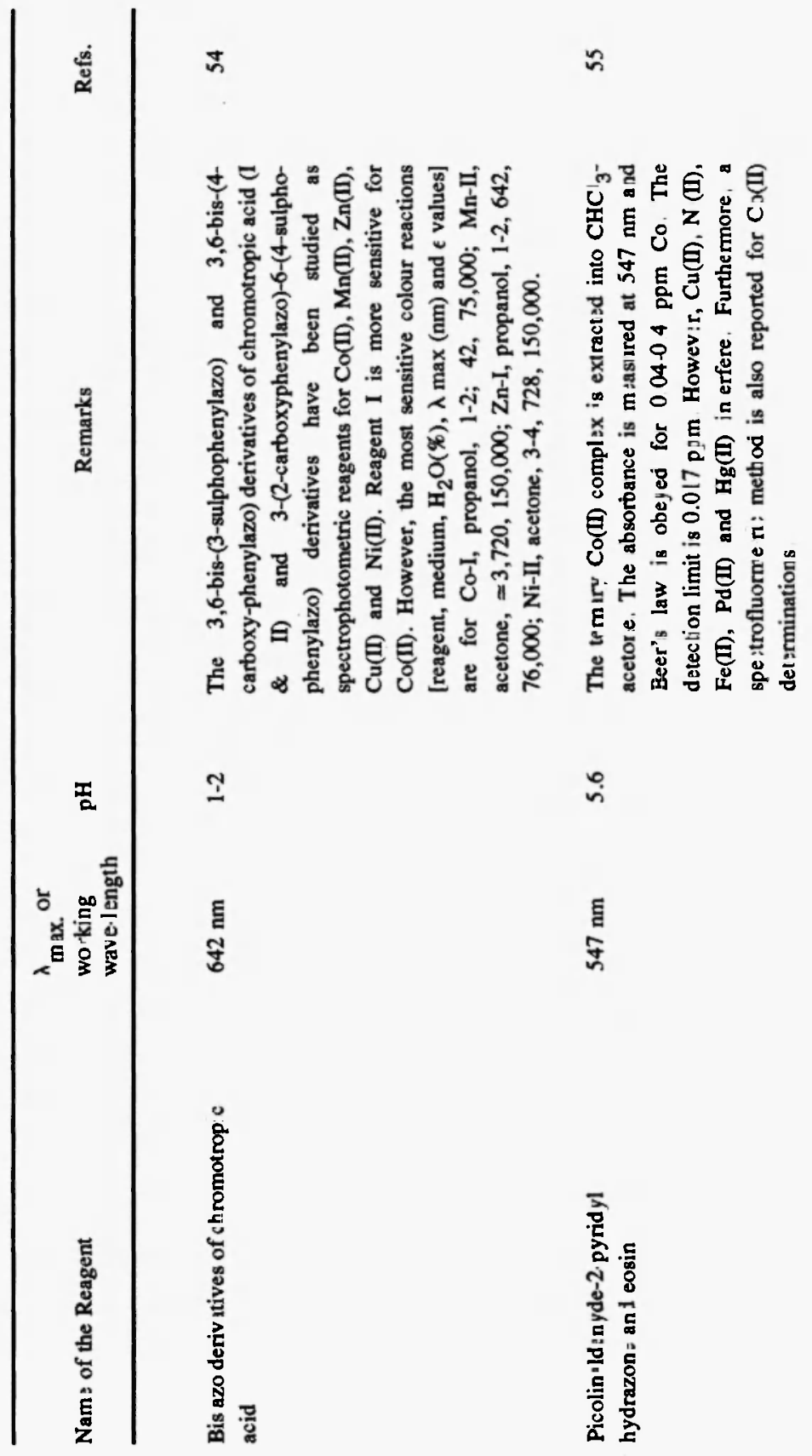




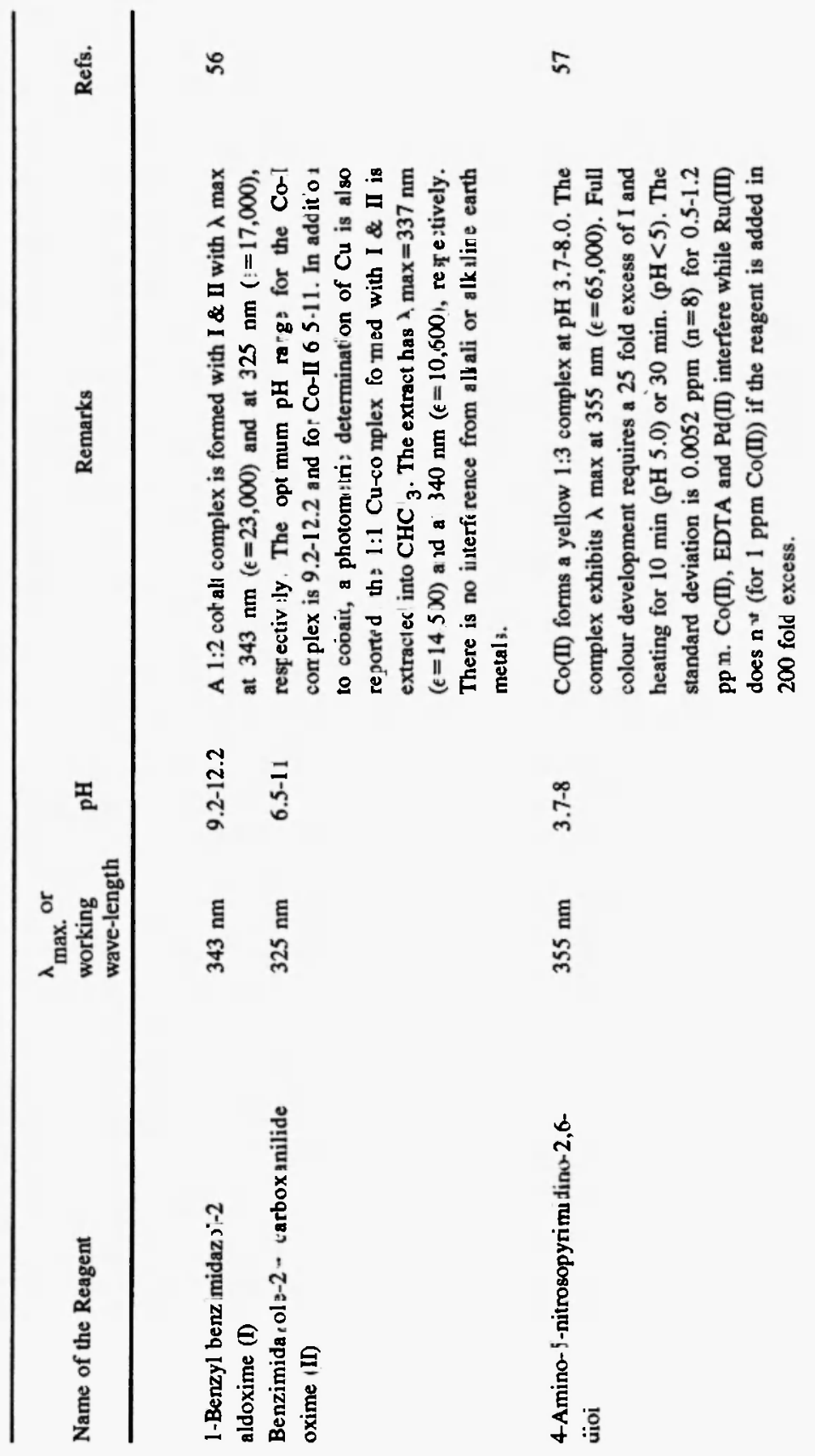




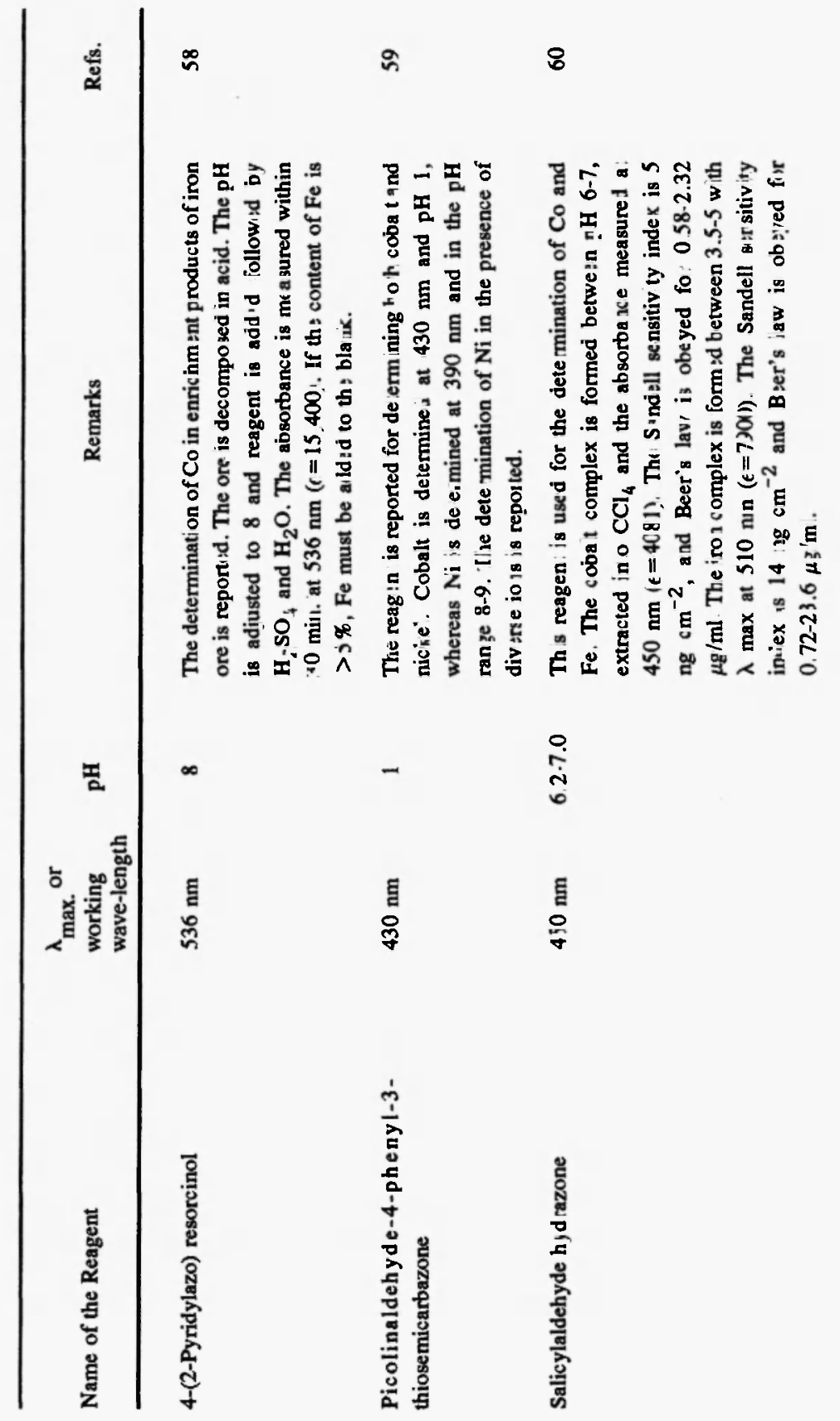




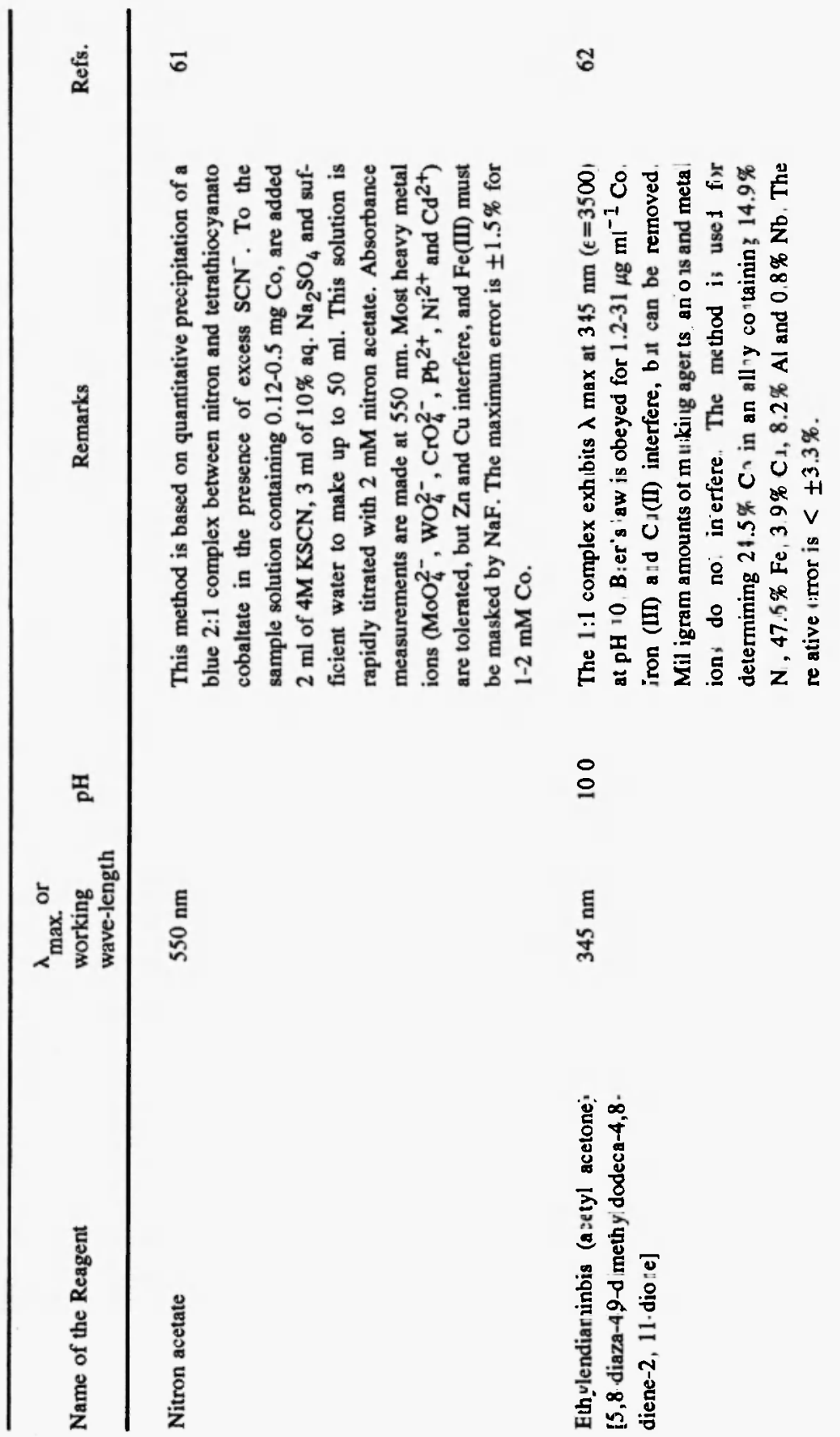




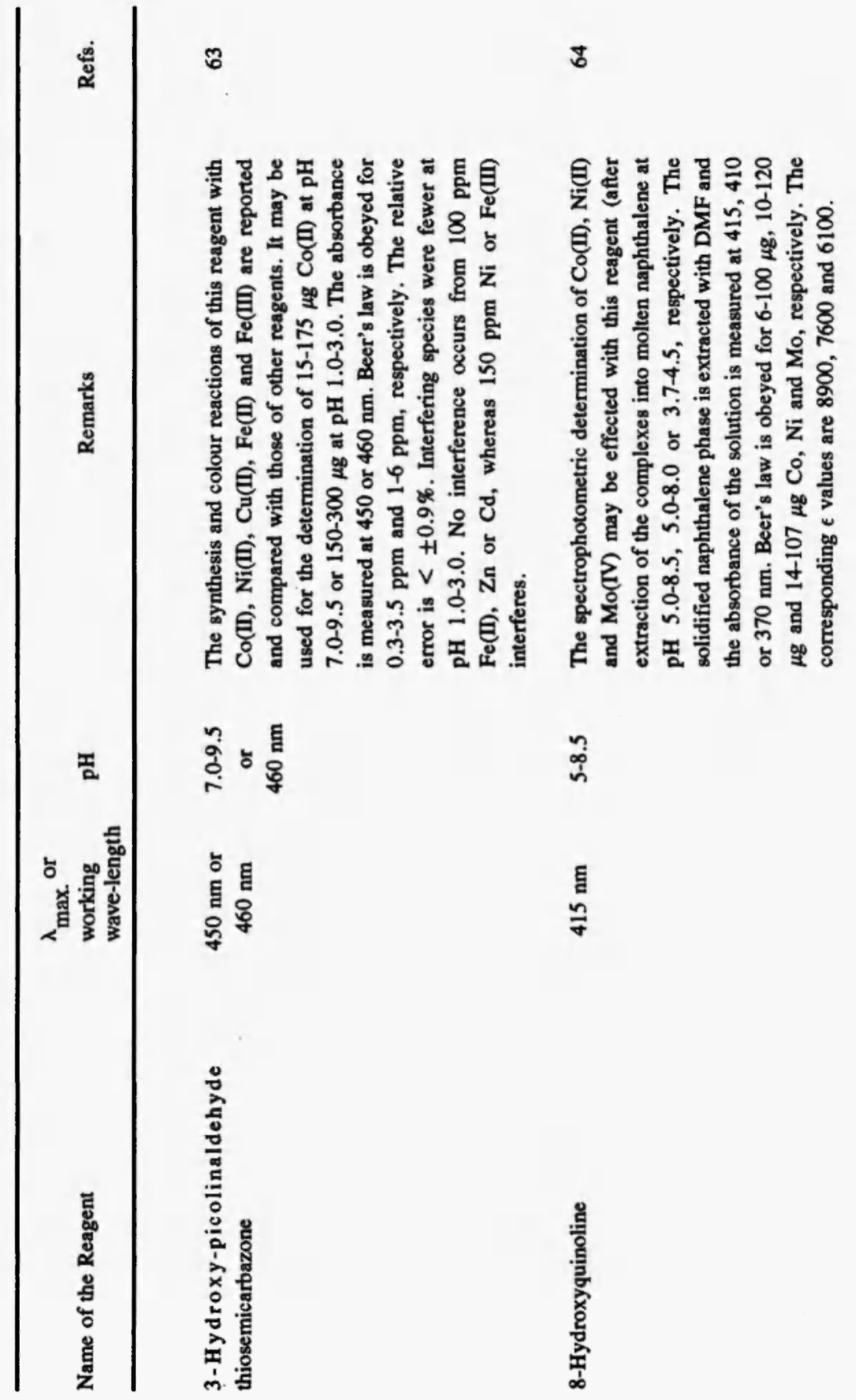




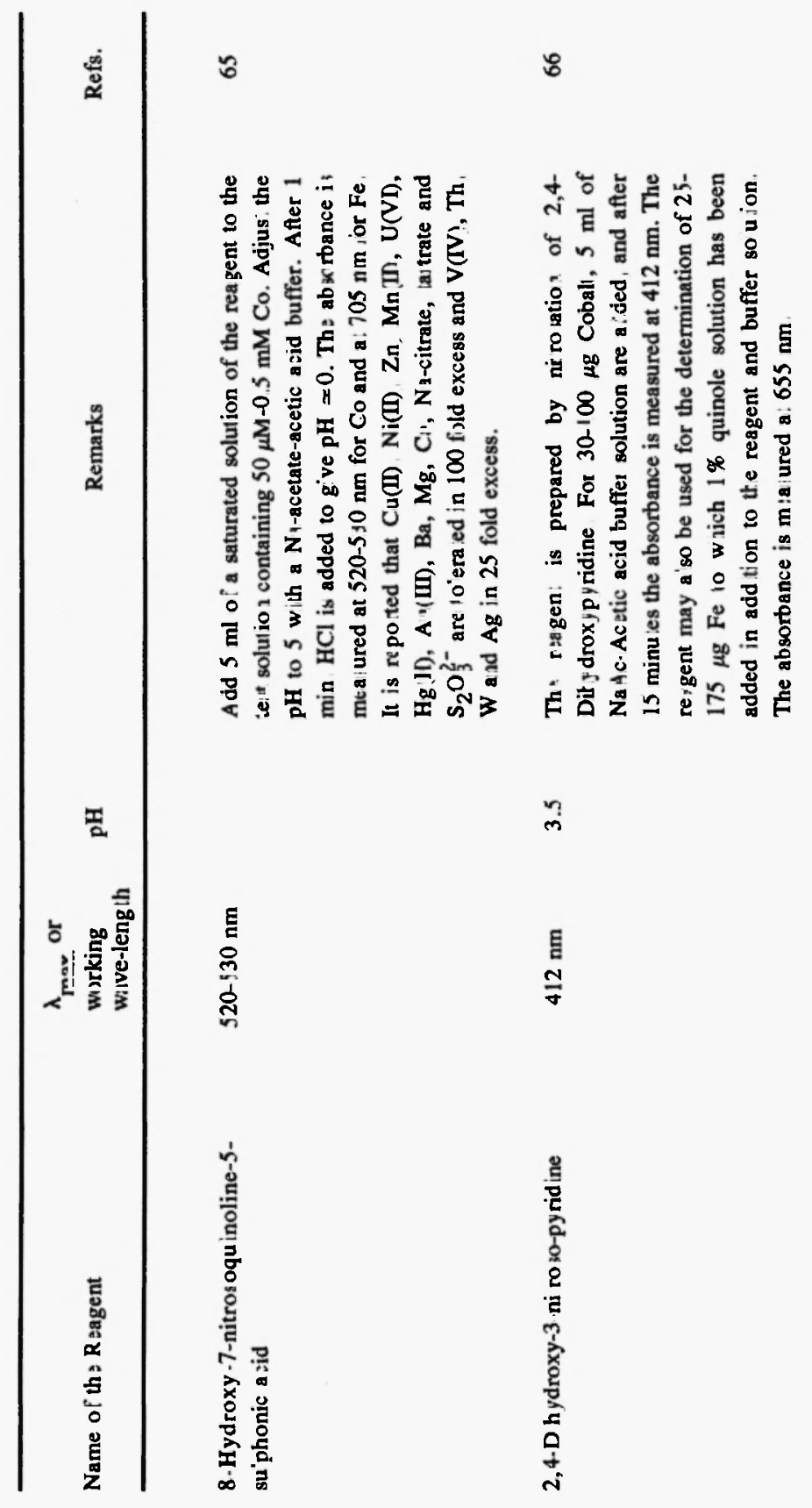




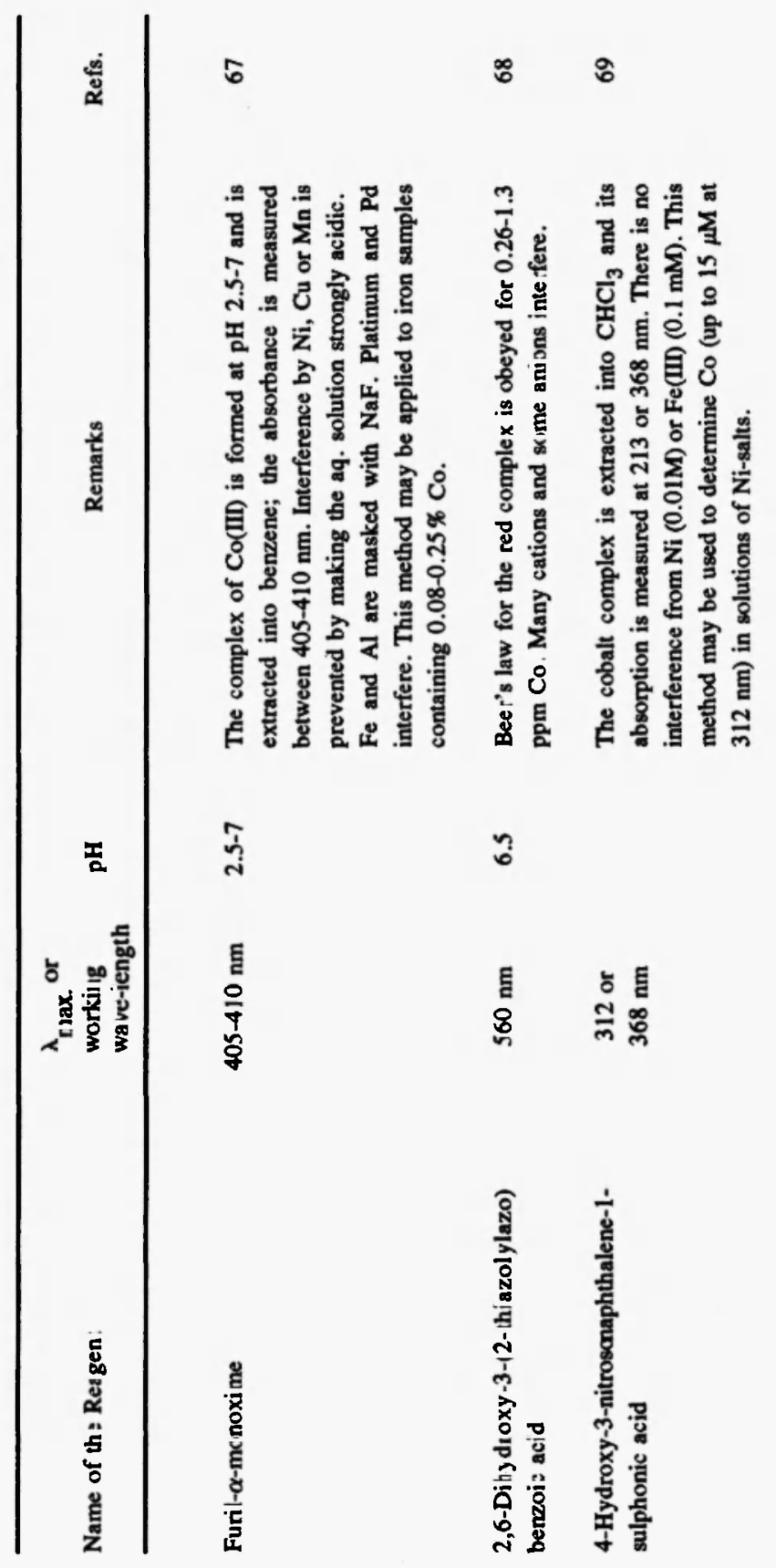




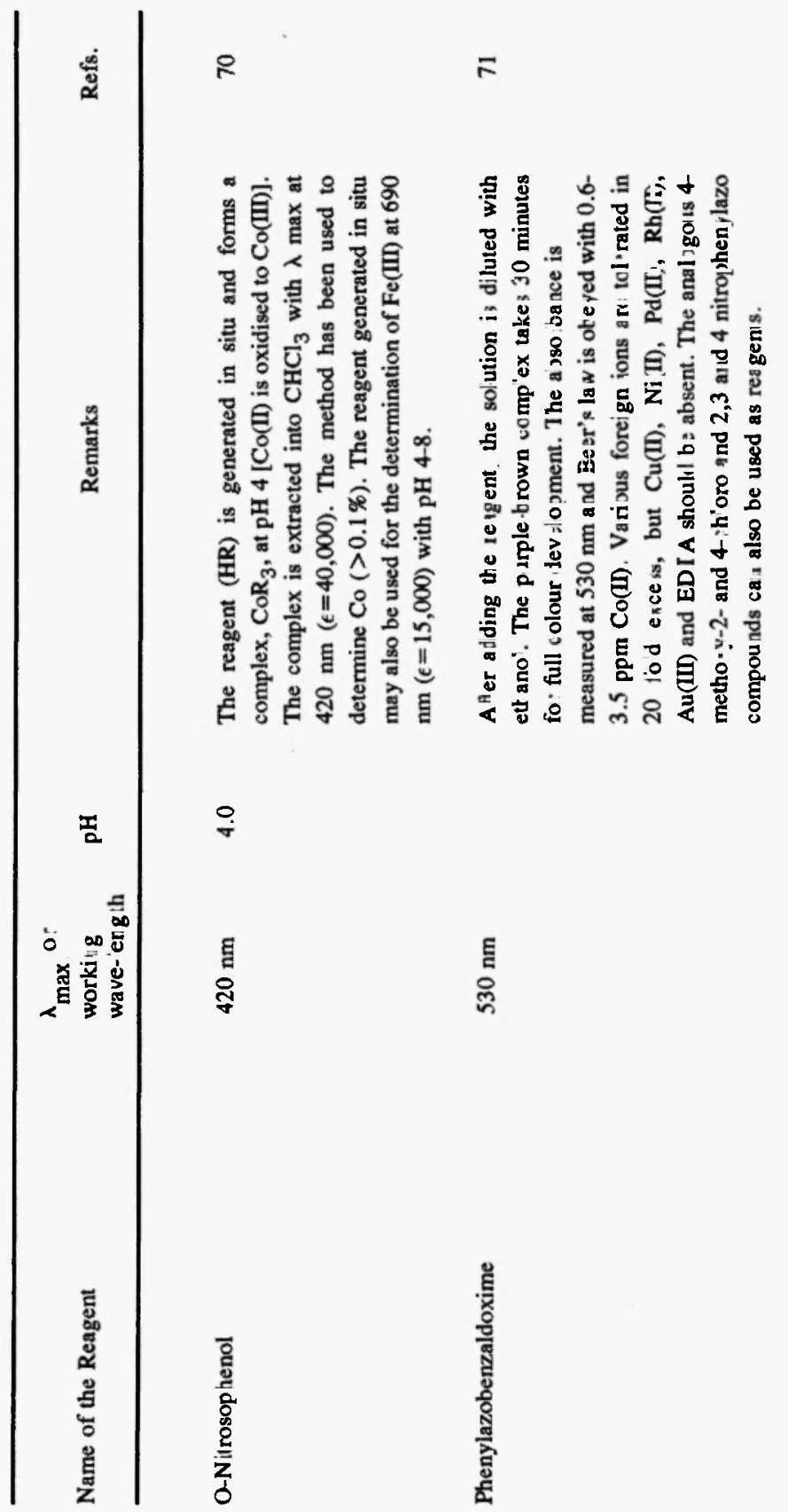




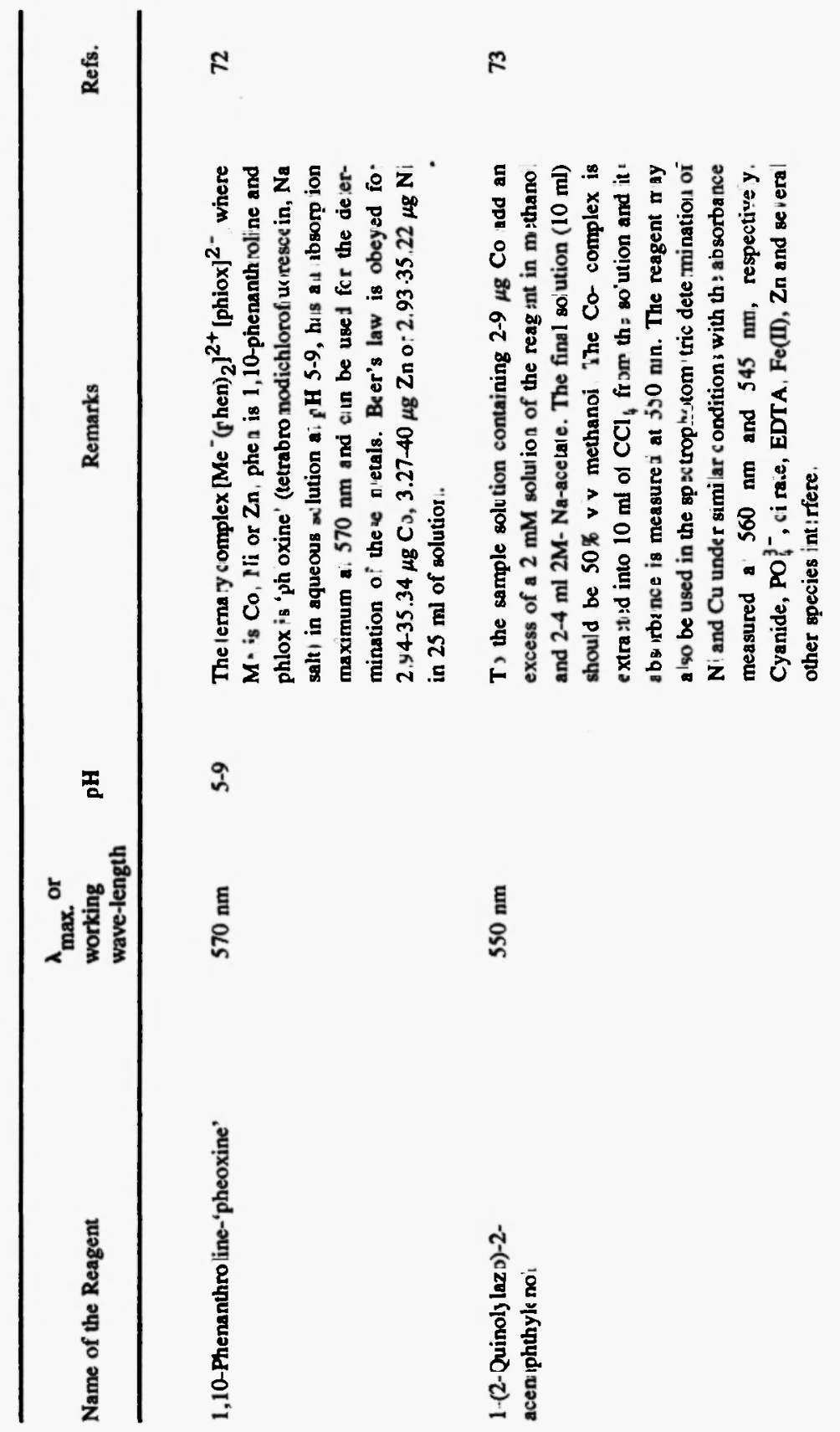




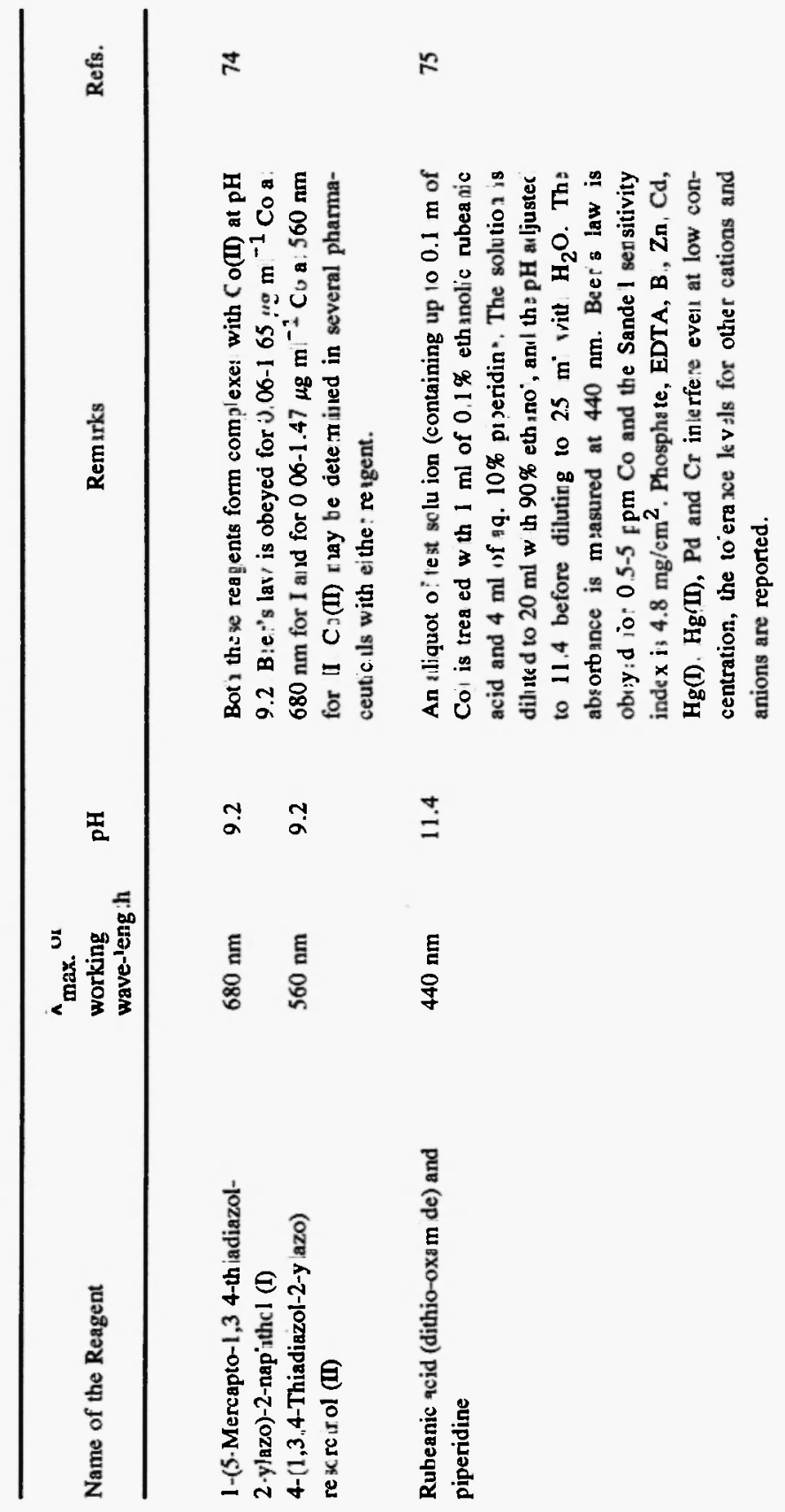




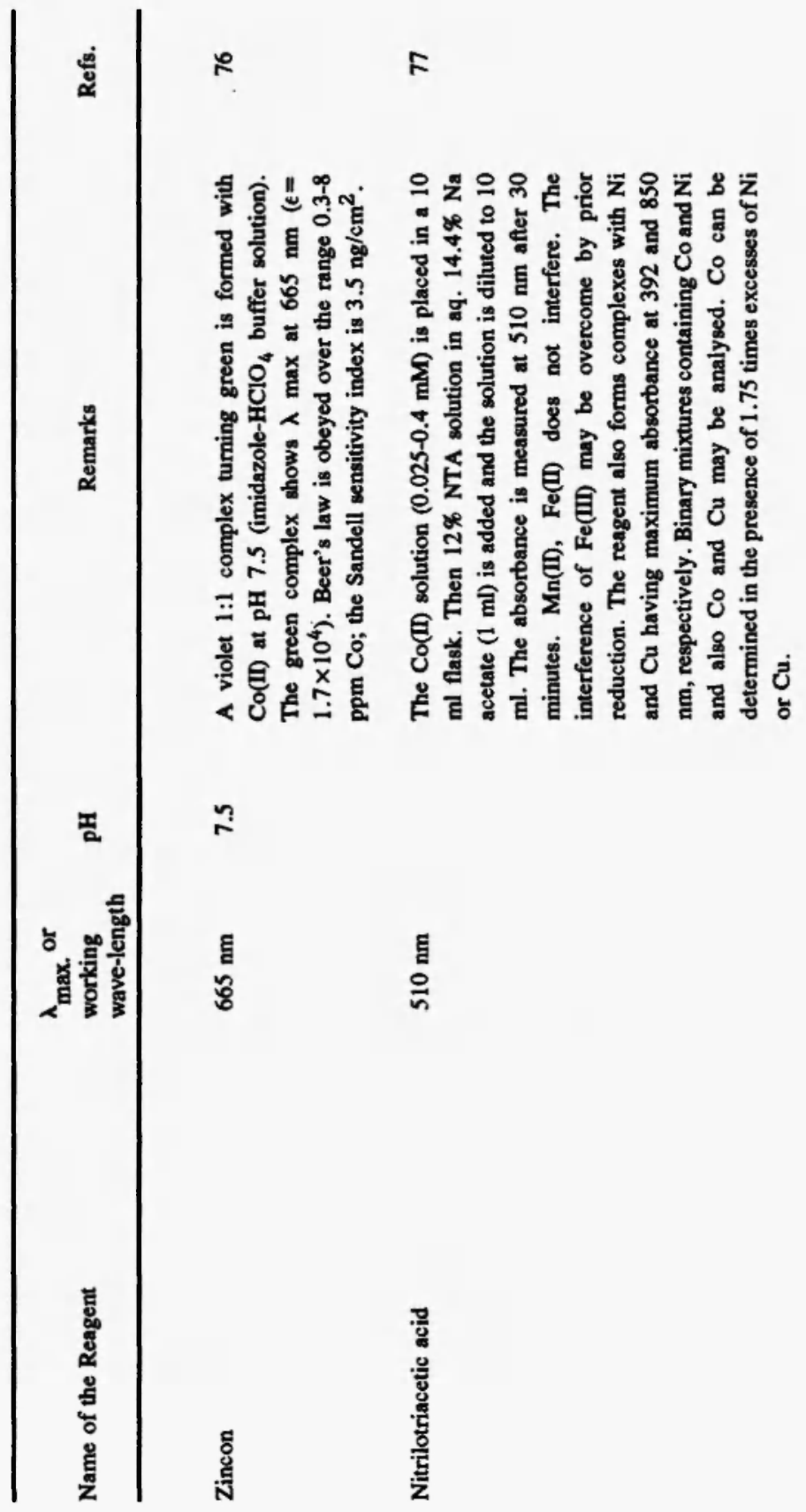




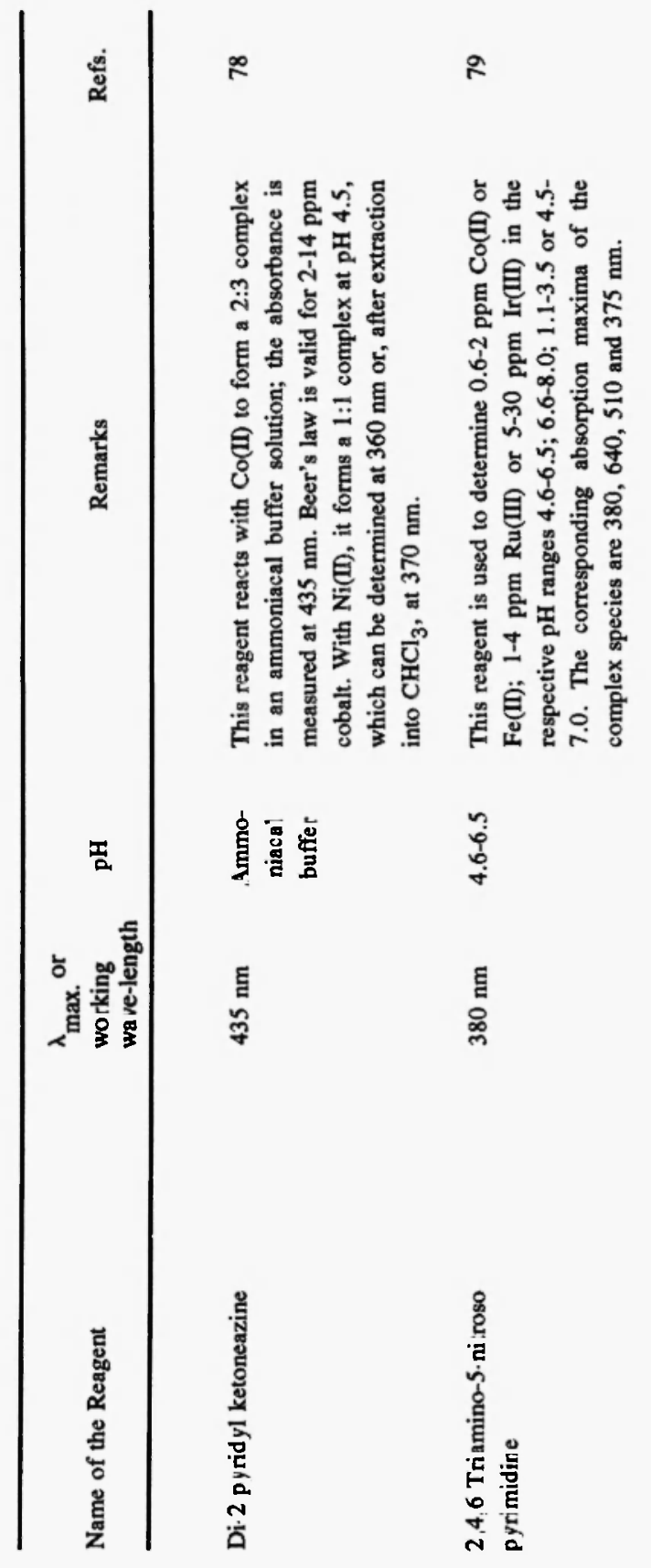




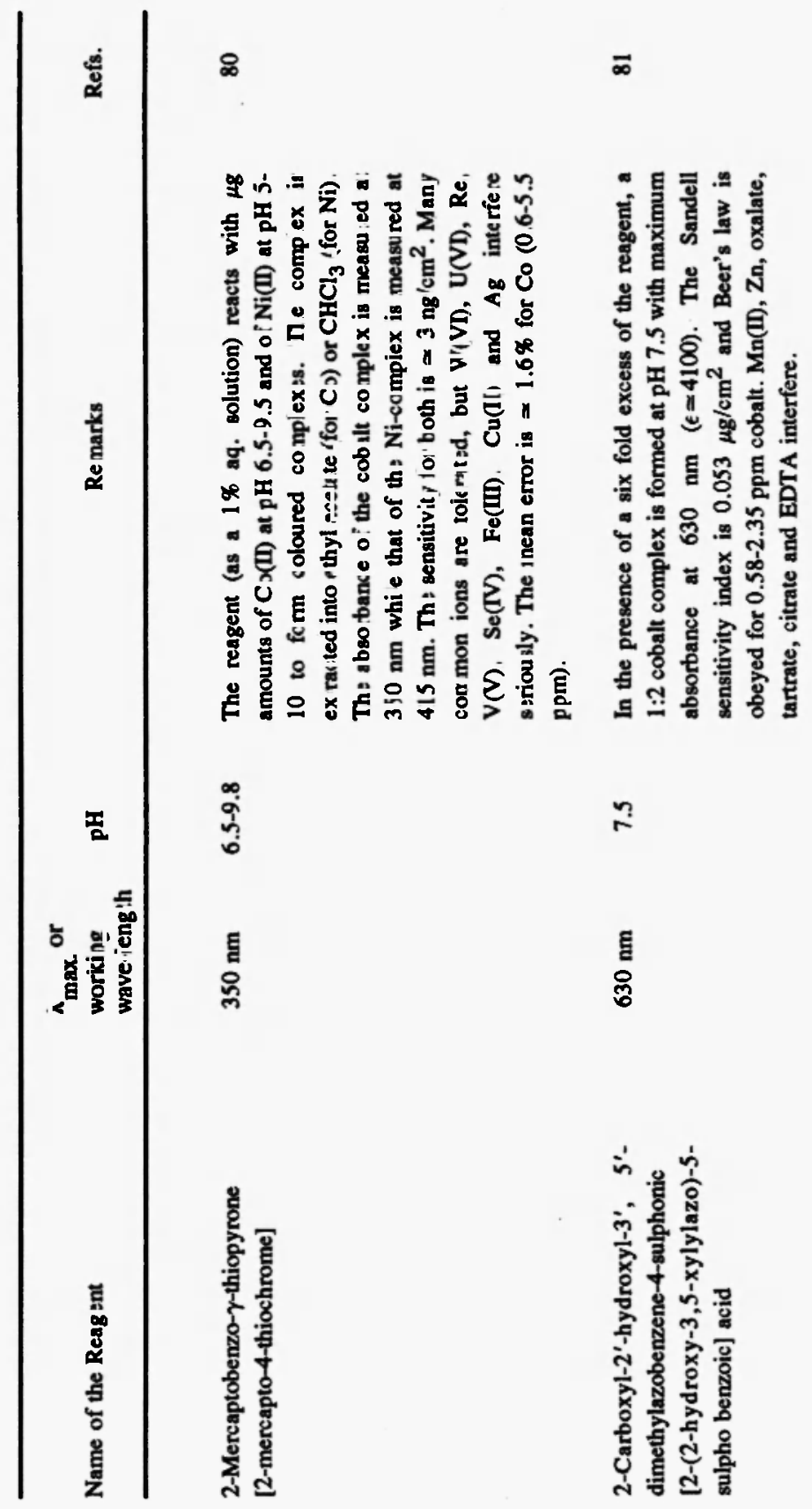




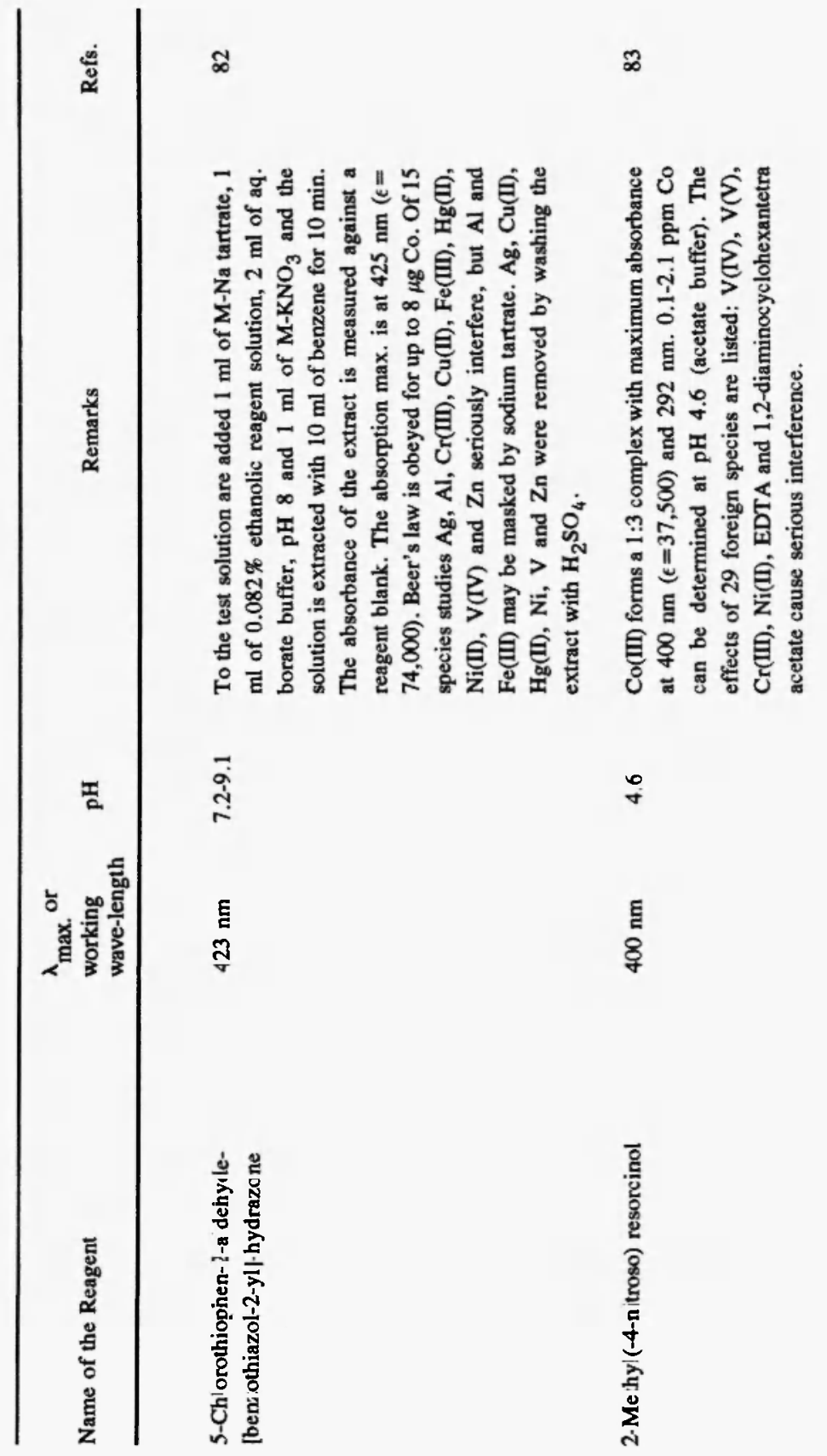




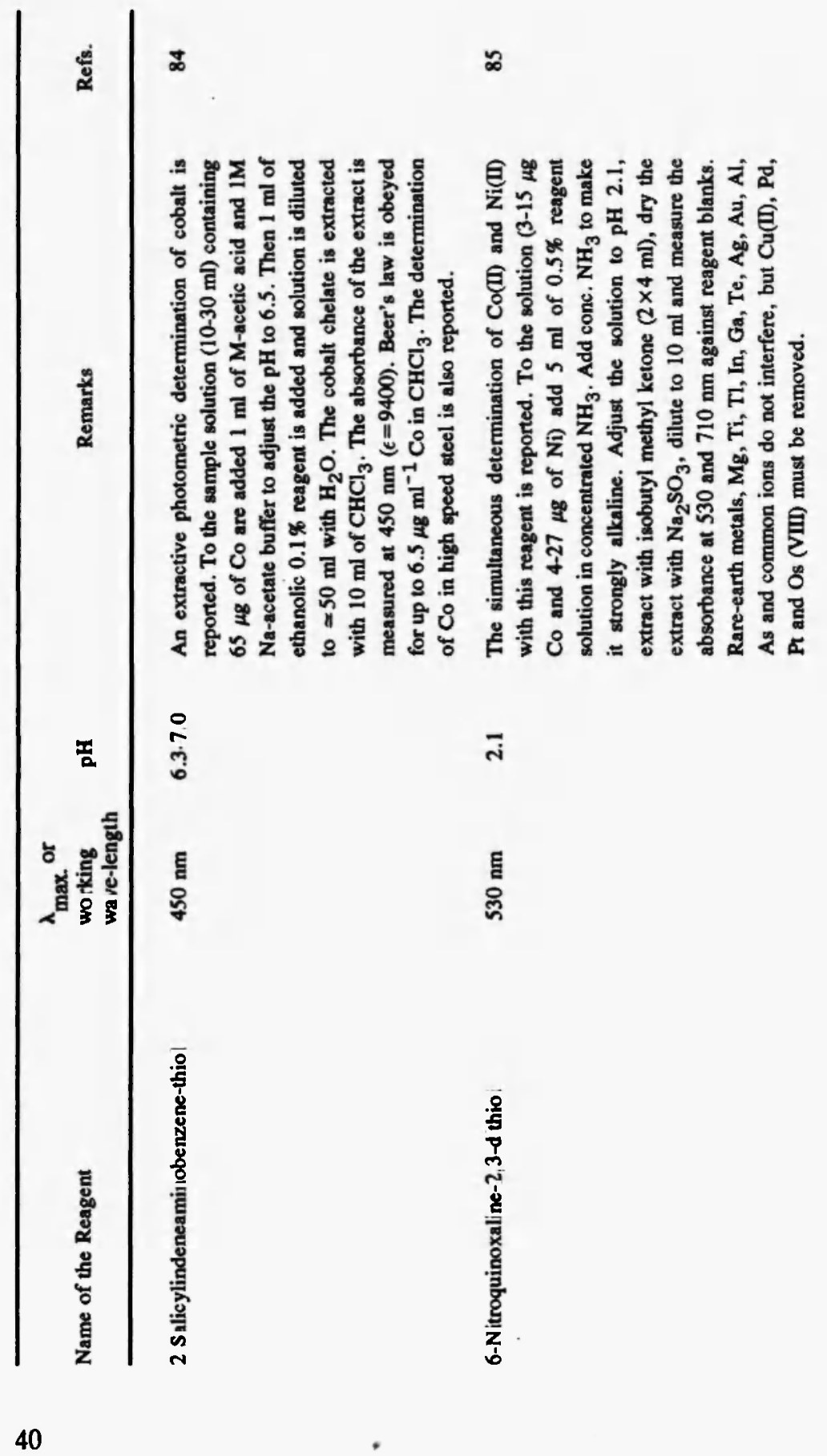




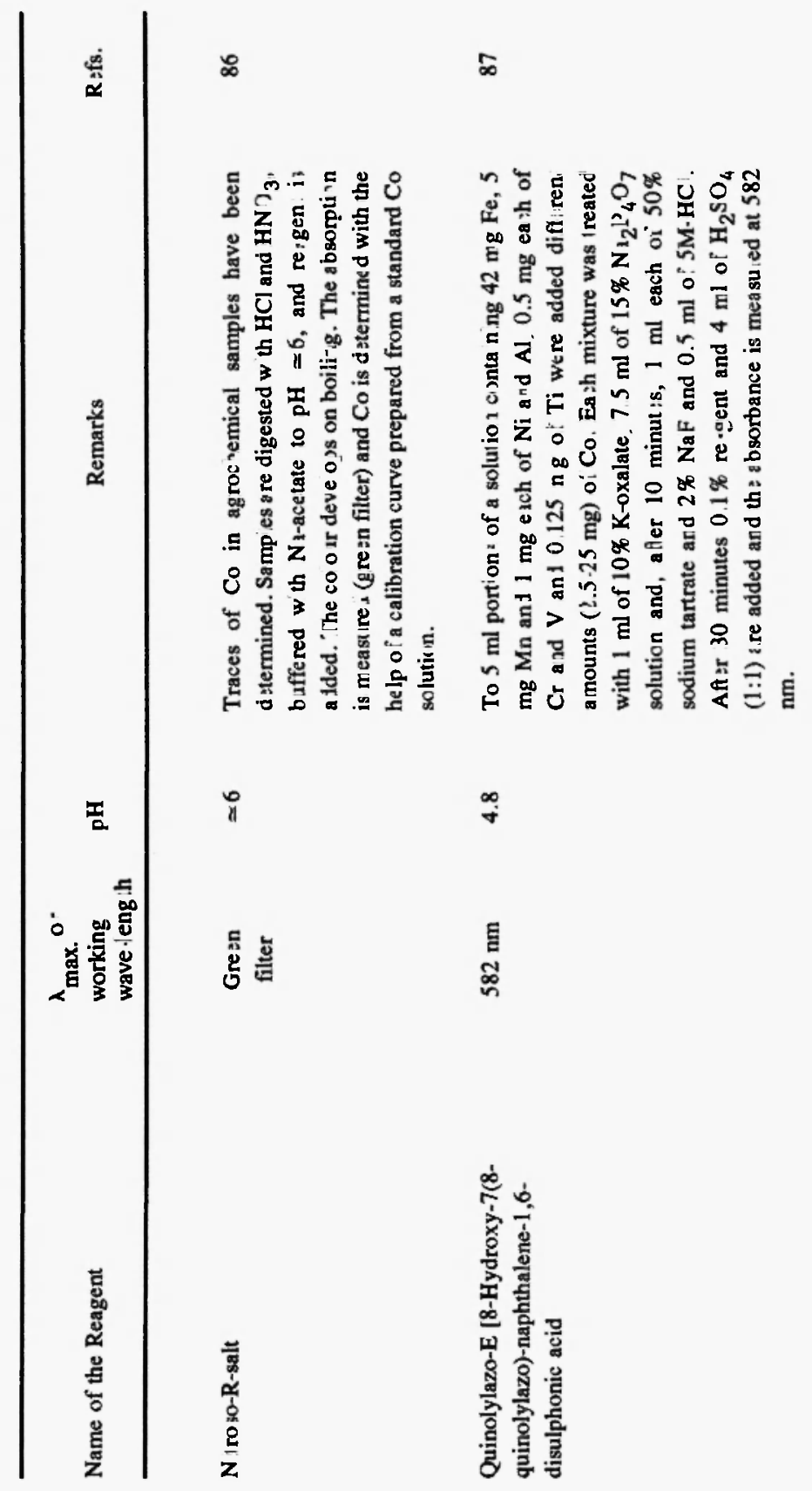




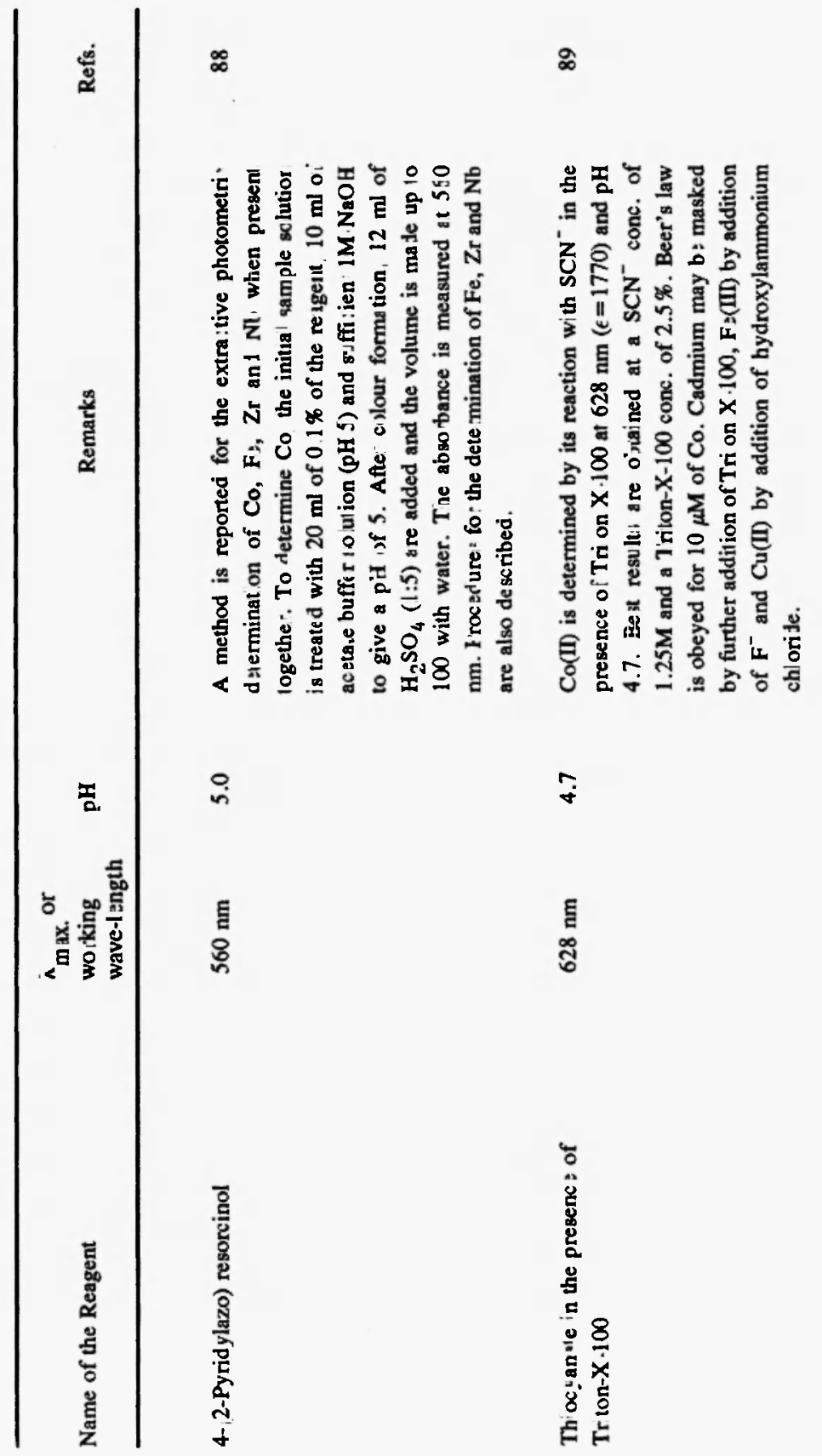




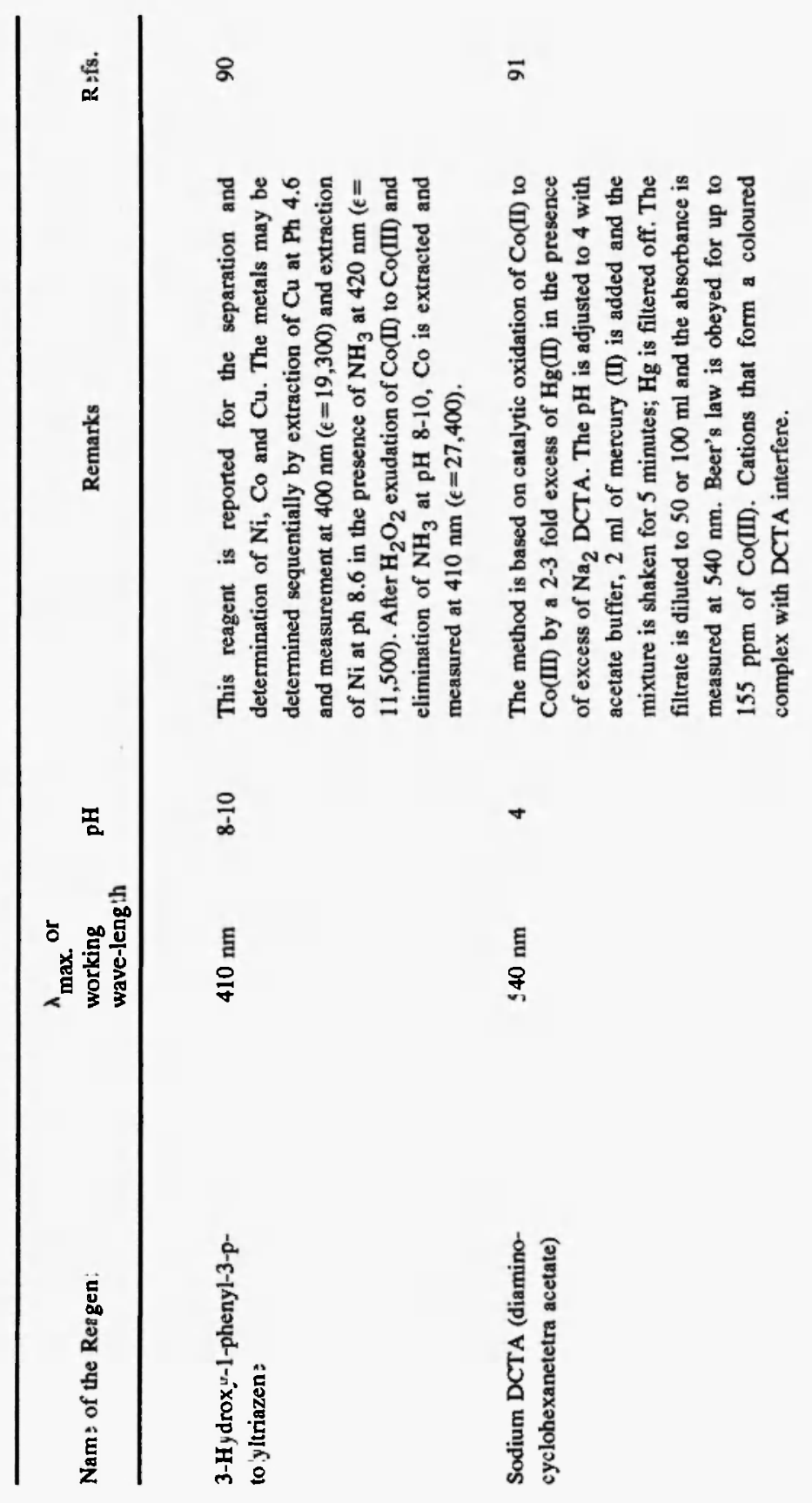




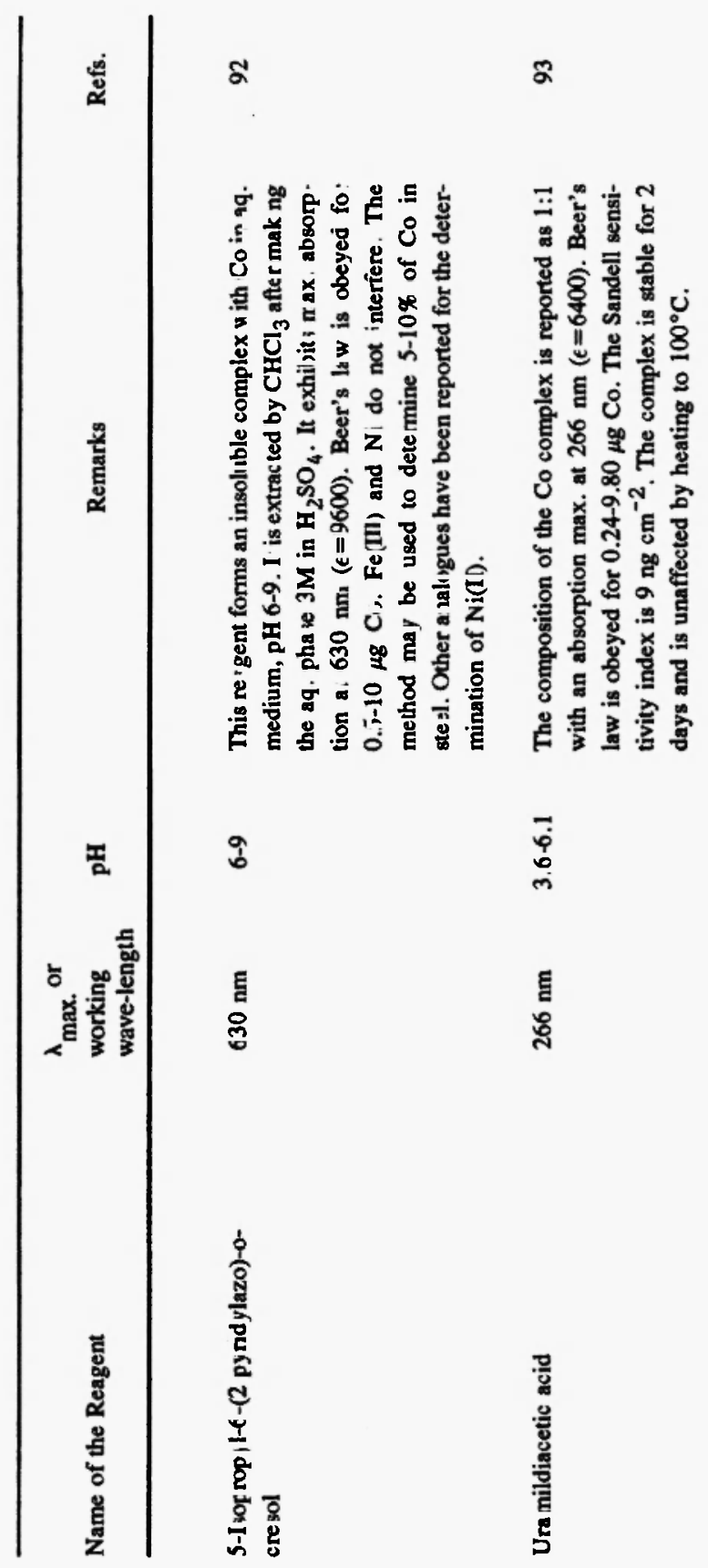




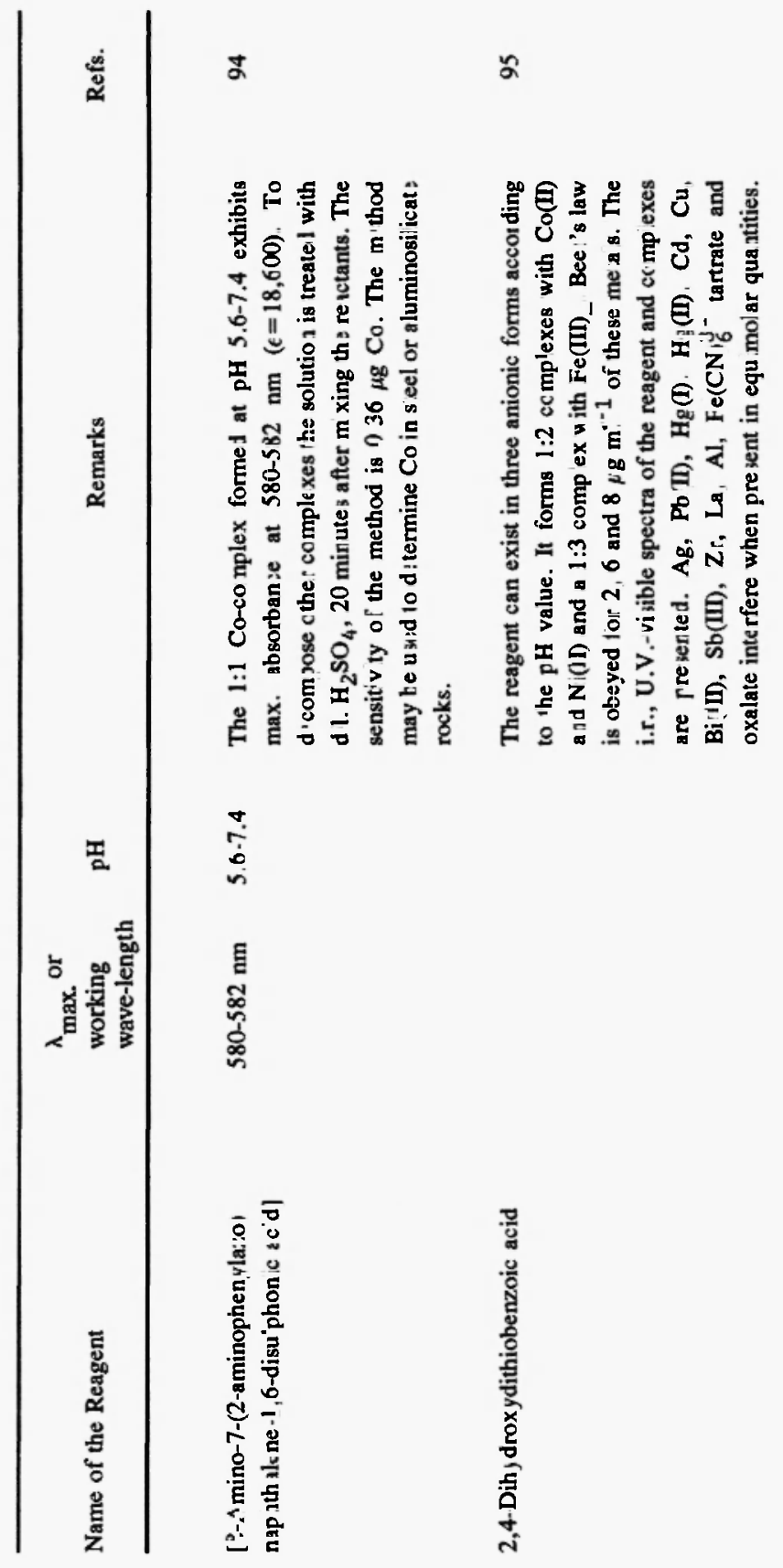




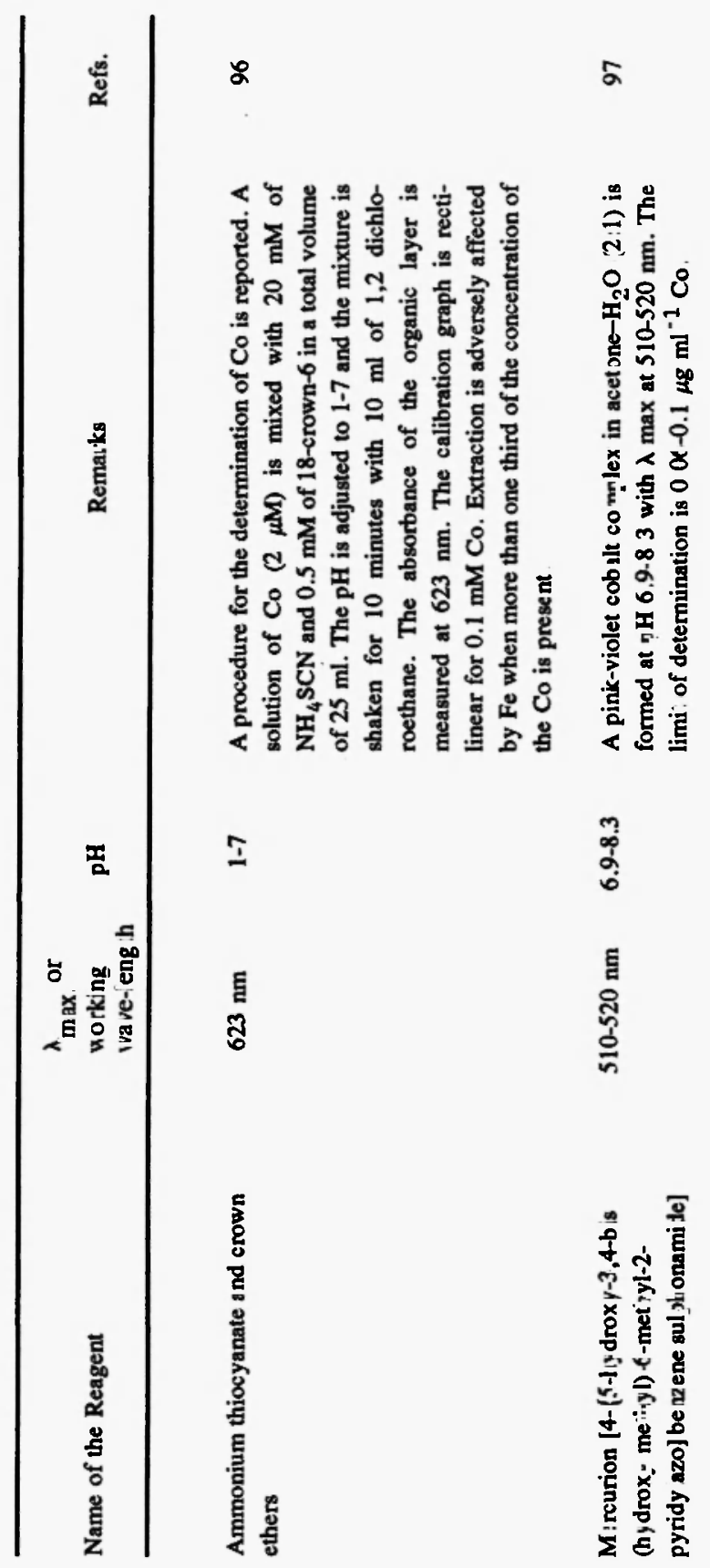




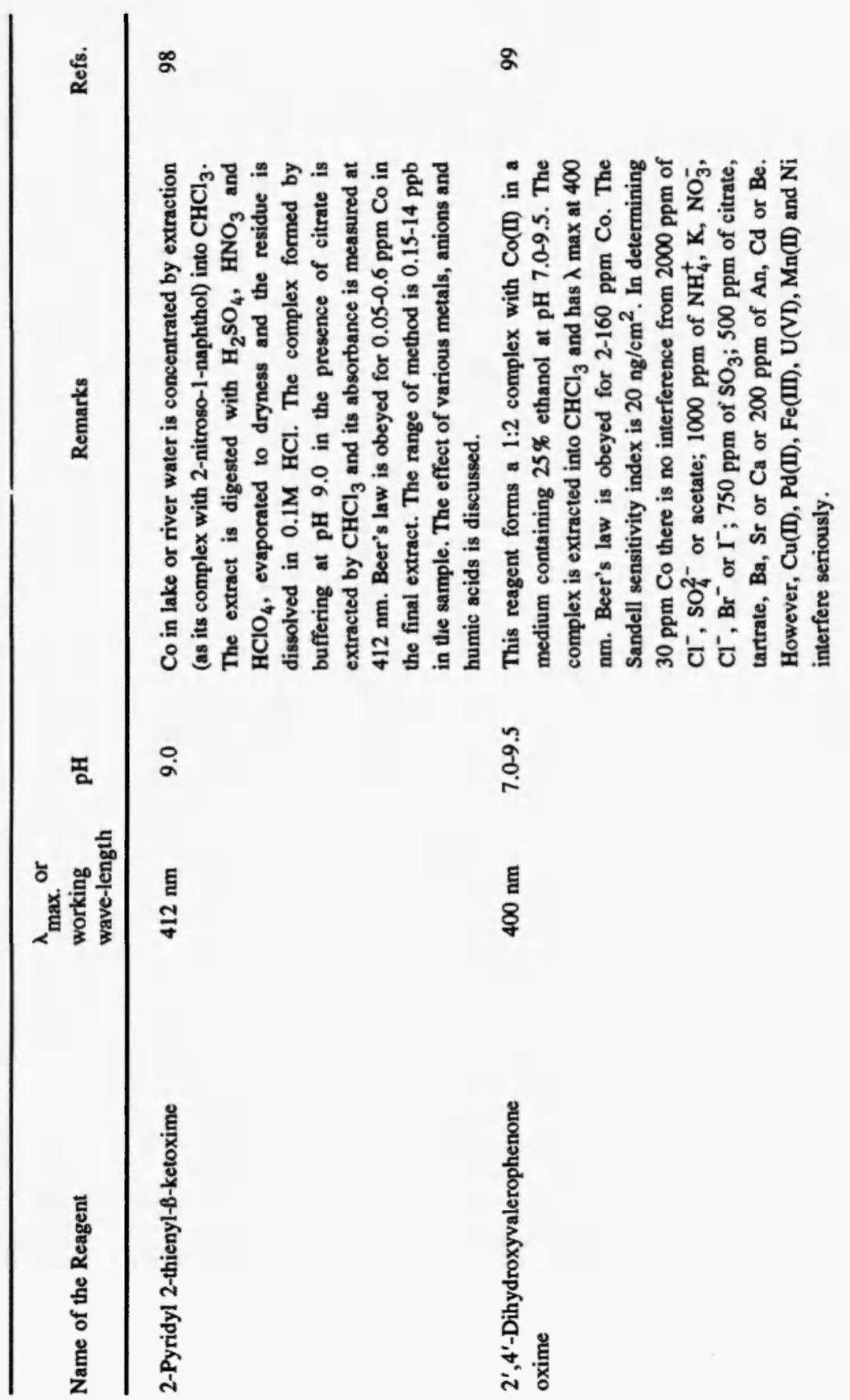




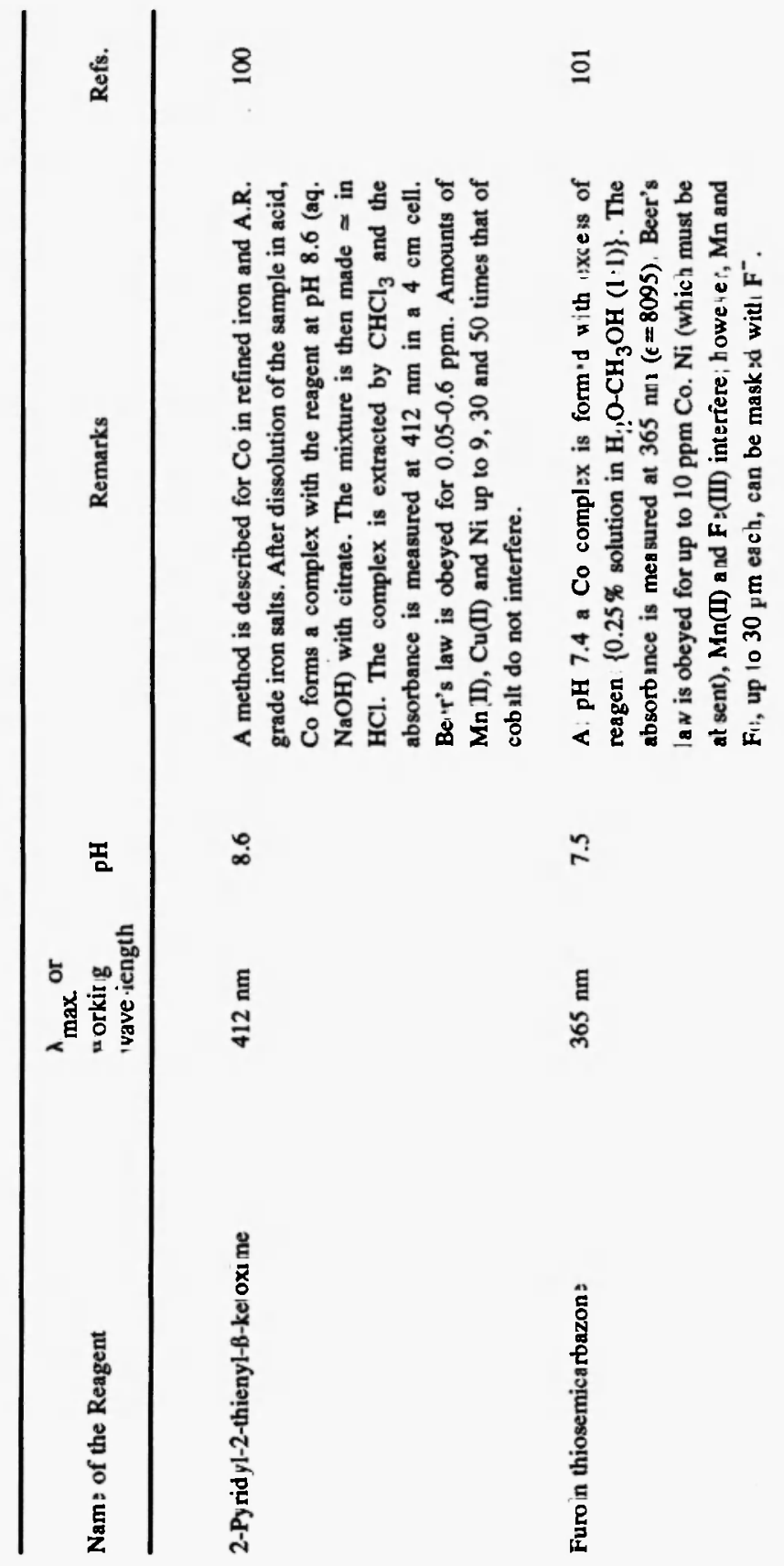




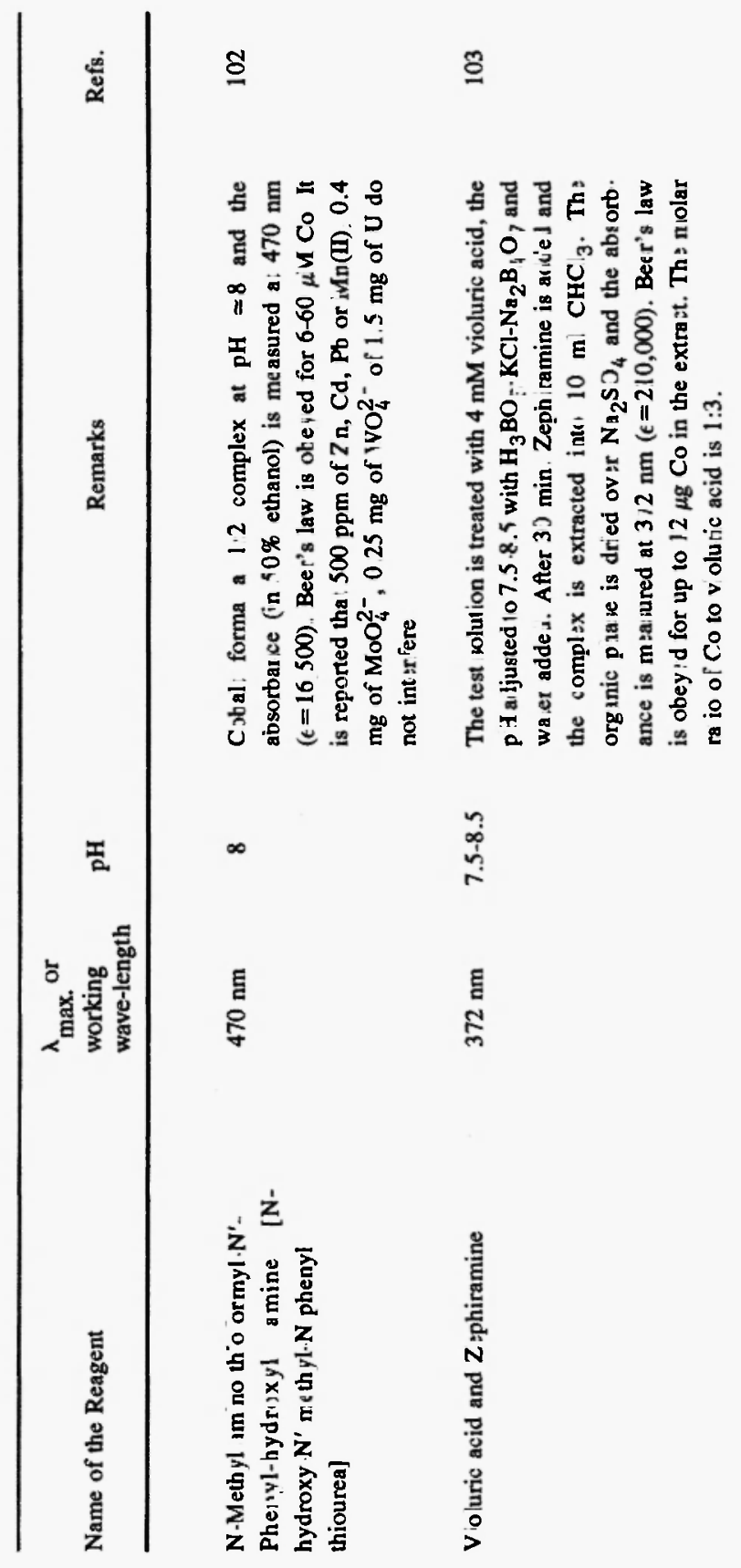




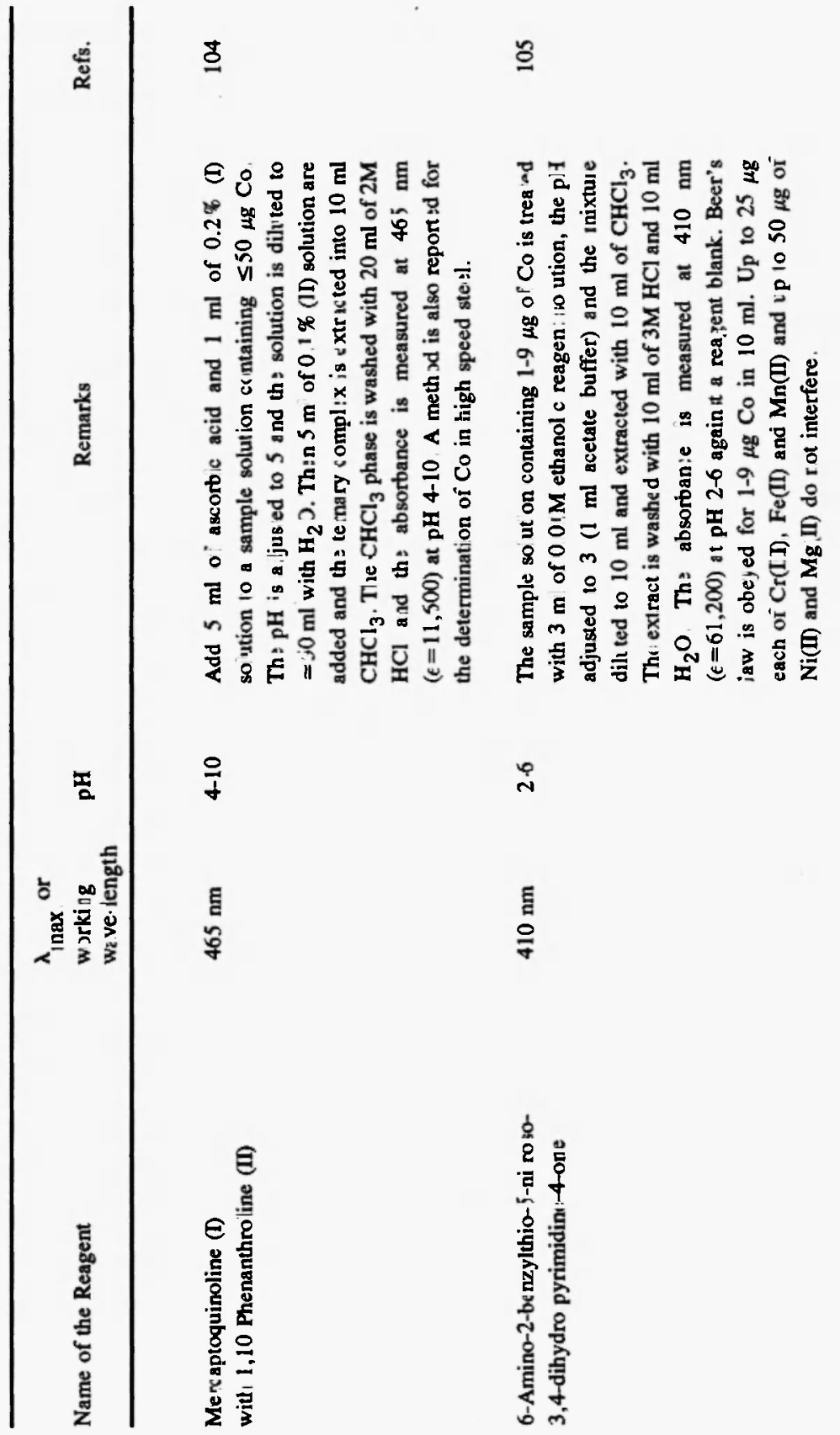




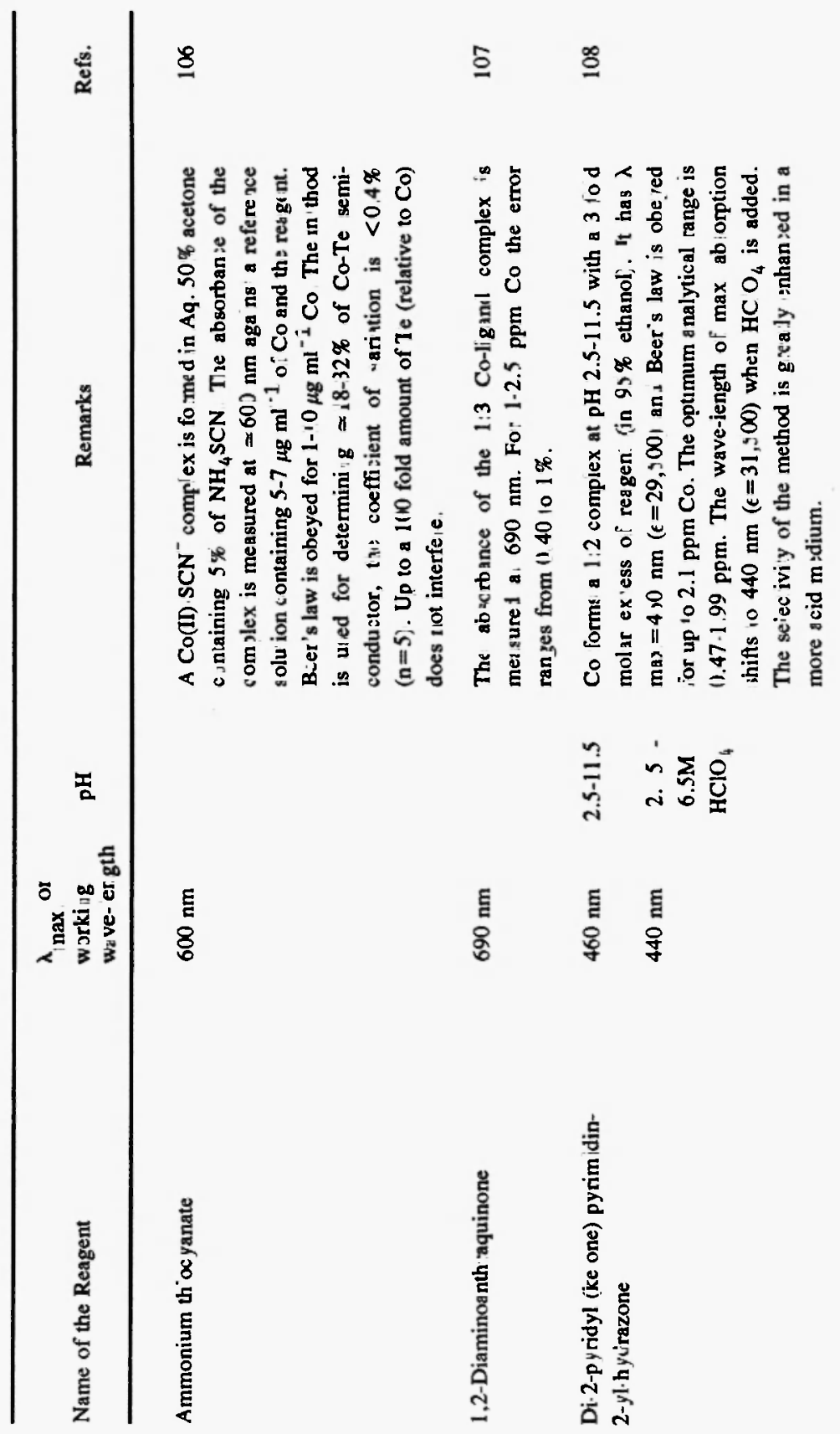




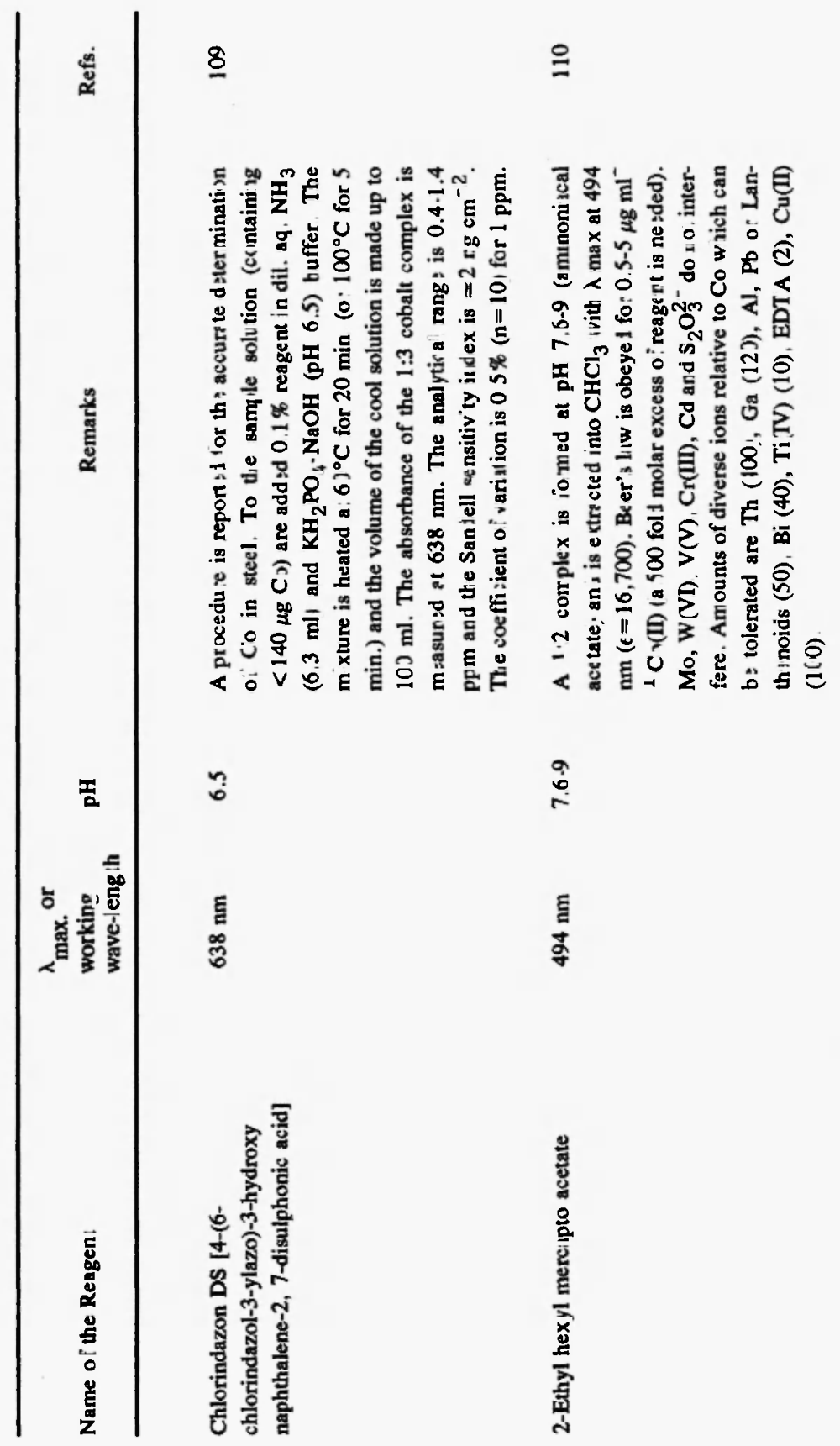




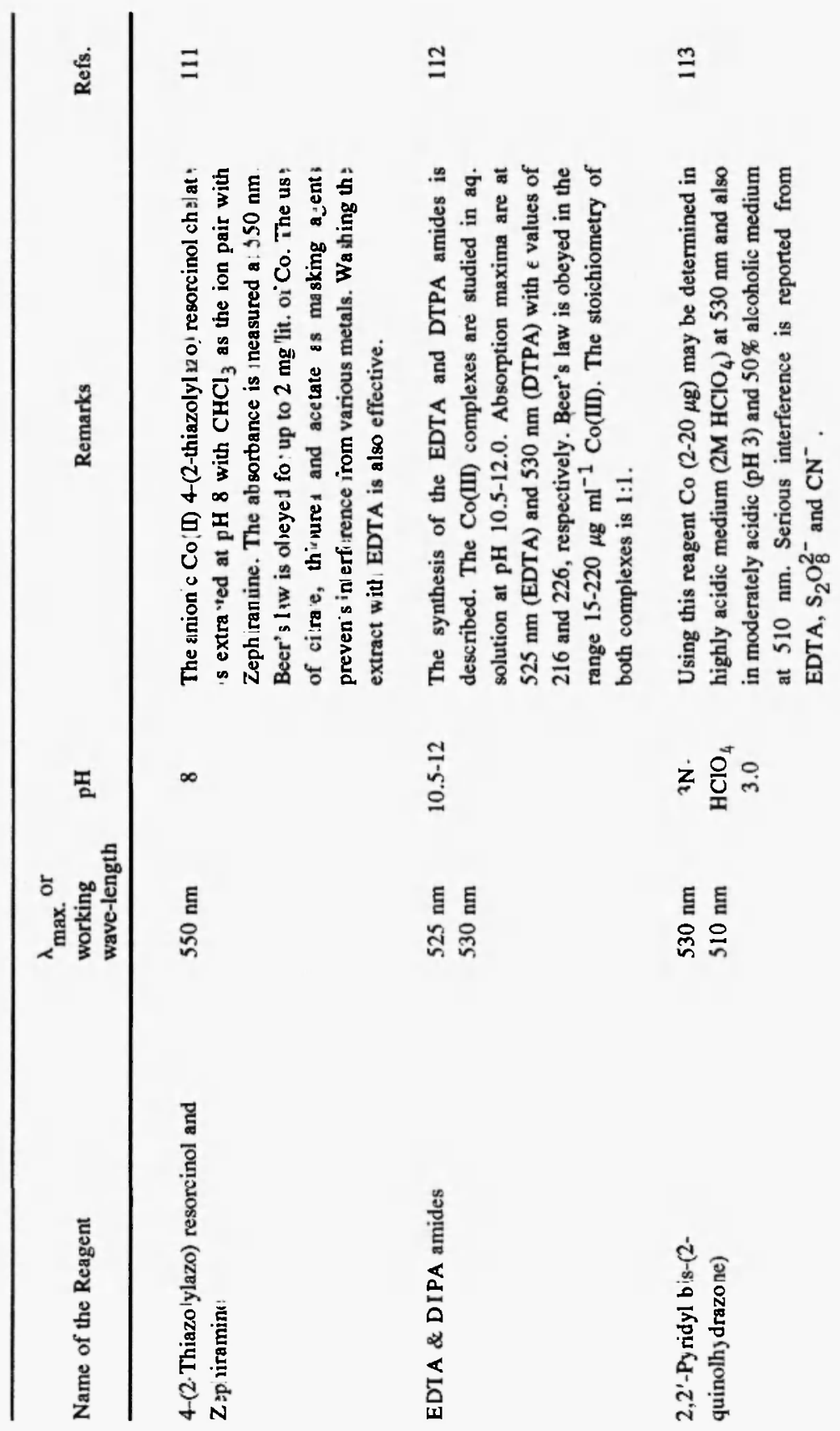




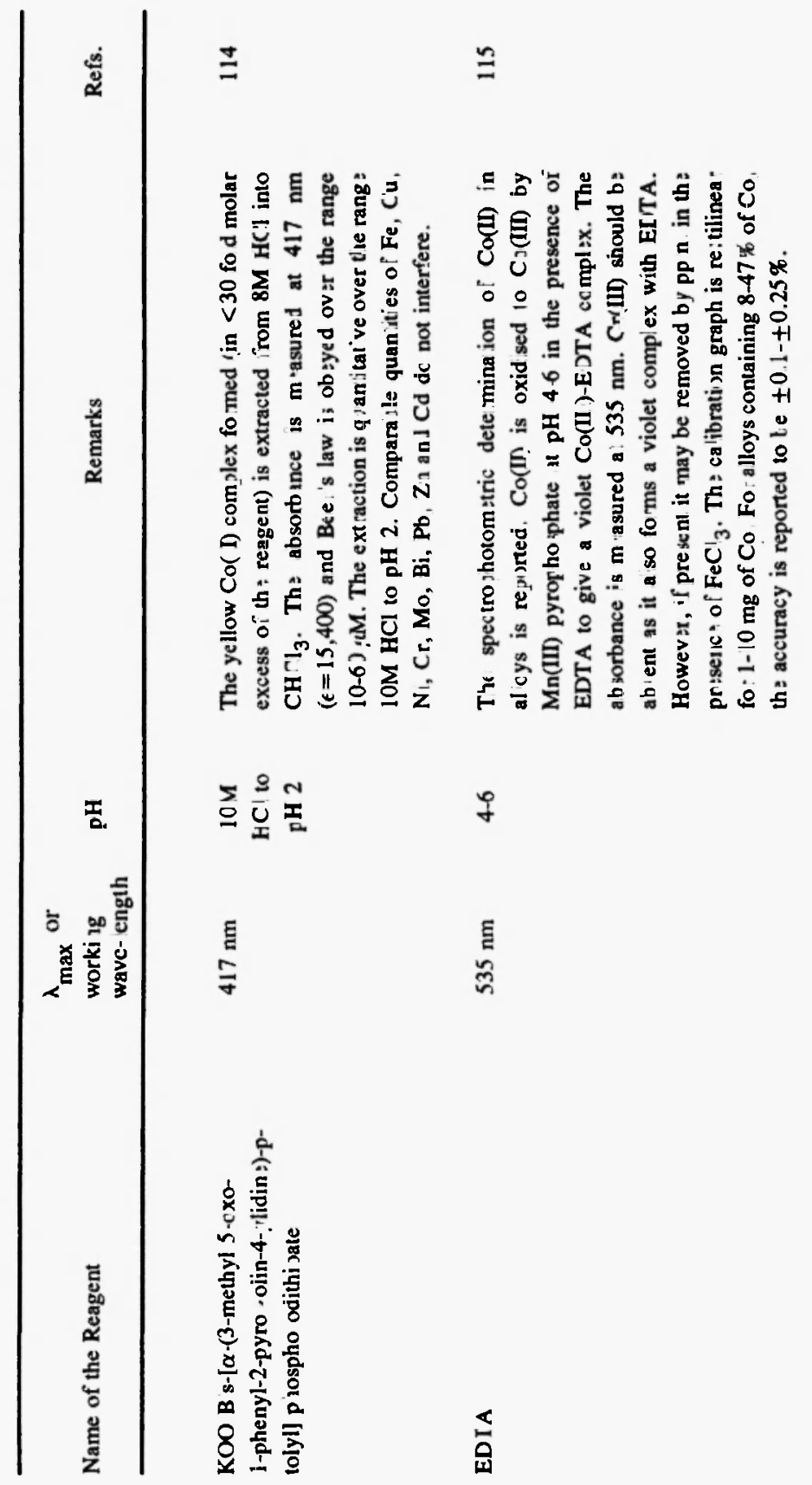




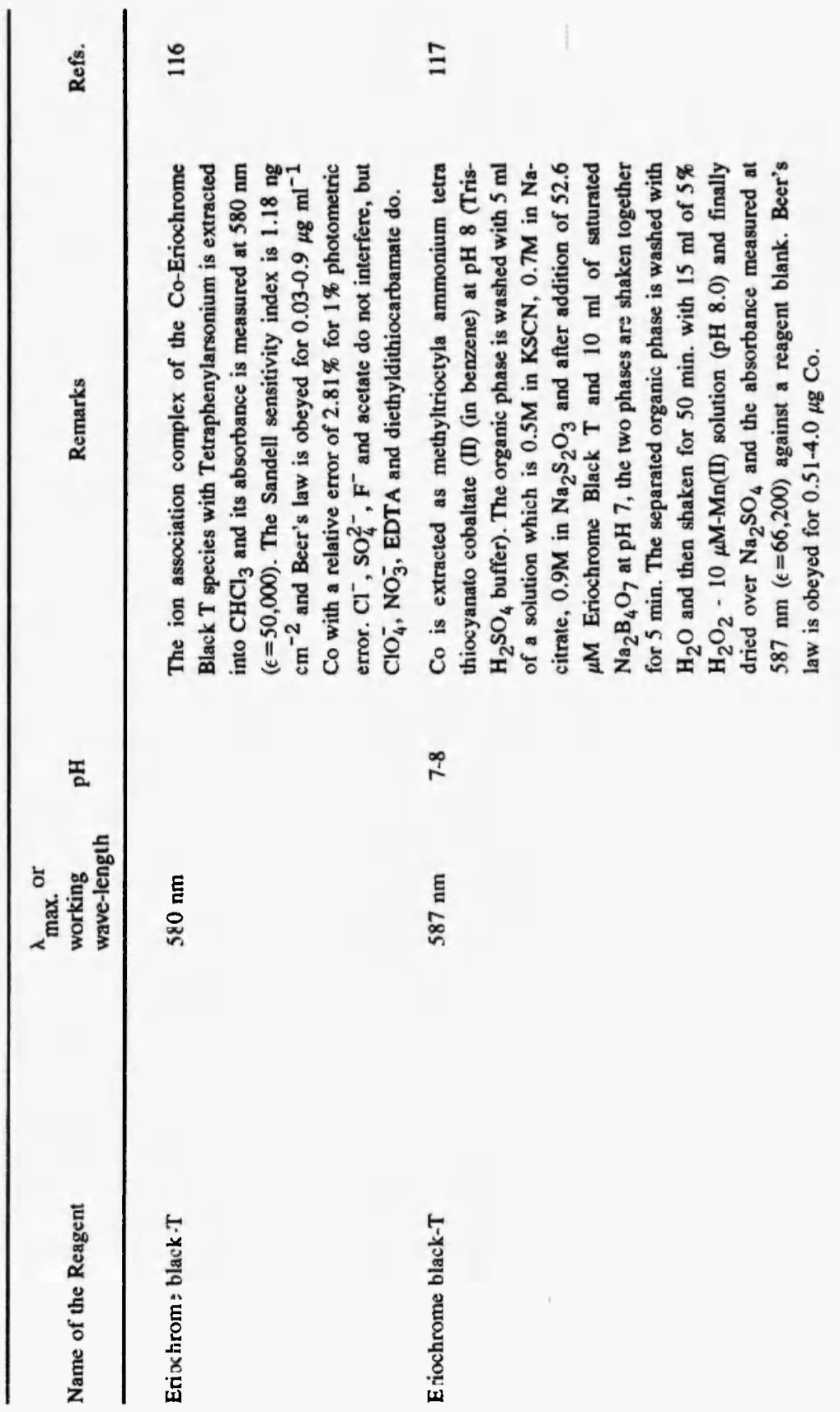




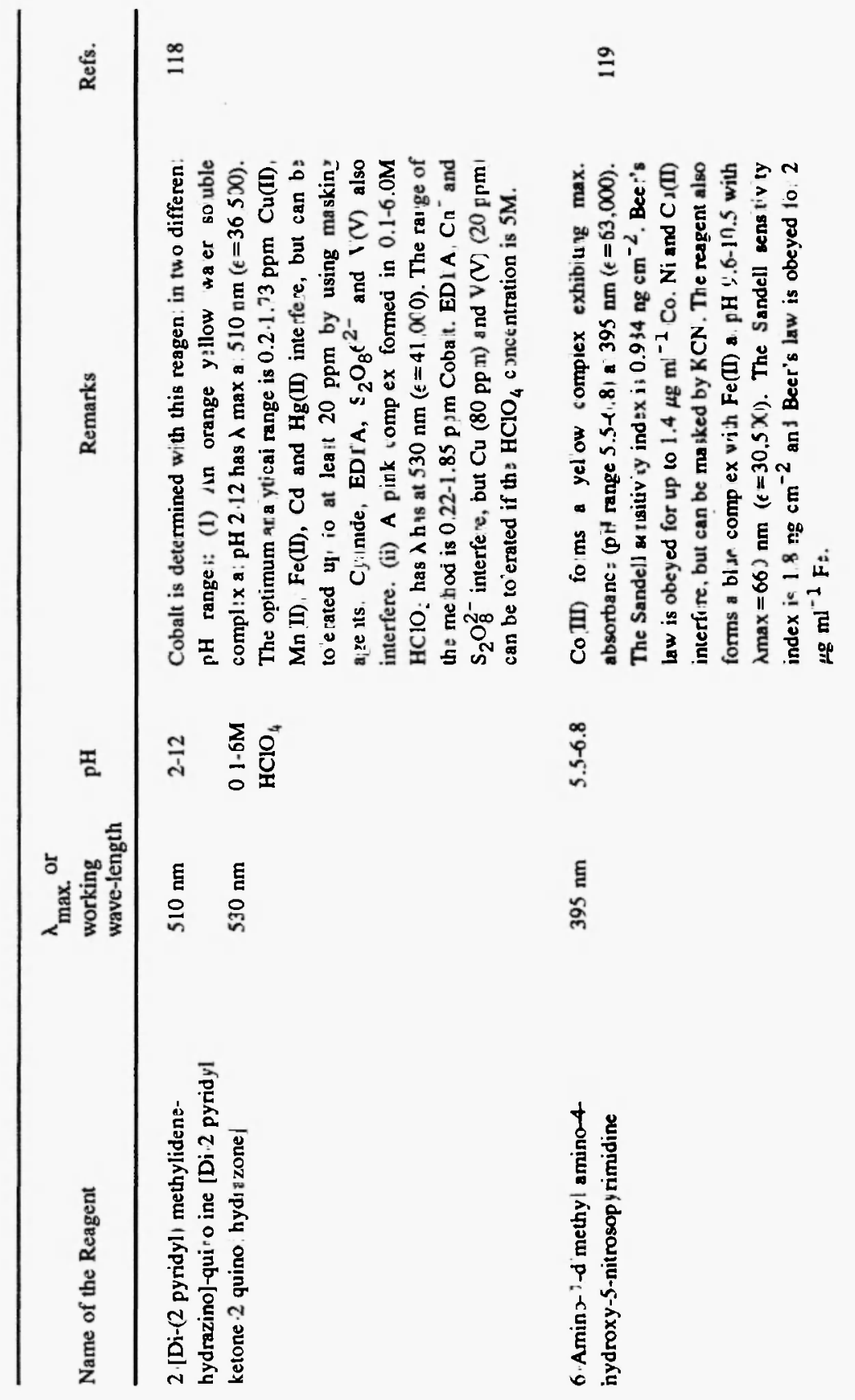




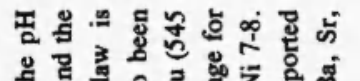
. 엉

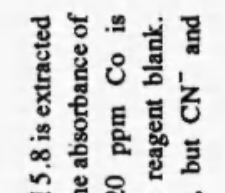
ह छ छ

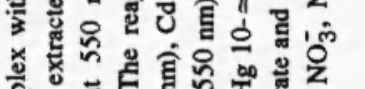

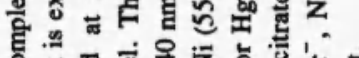

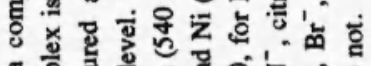
ส

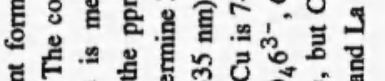

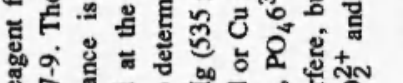

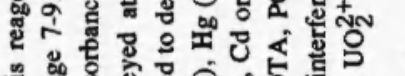

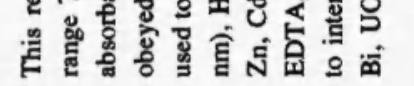

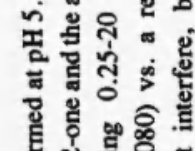

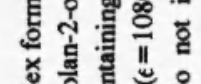

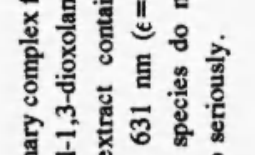

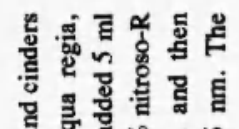

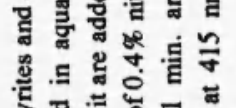

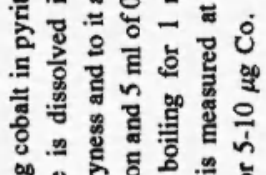

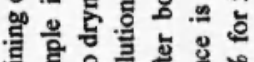

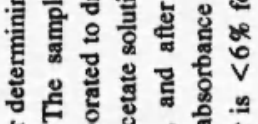

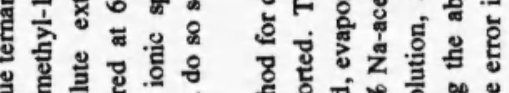

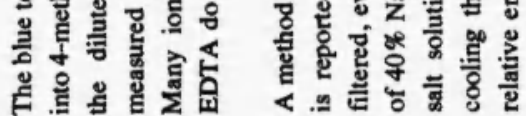
$\stackrel{a}{n}$
$\dot{\omega}$
$\stackrel{a}{z}$
$\stackrel{1}{1}$
กั

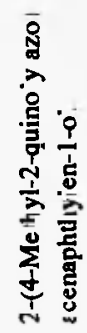

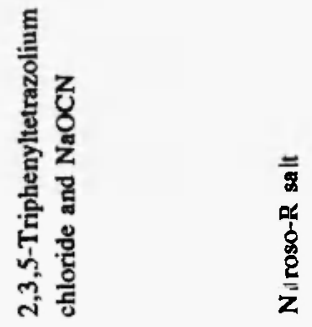




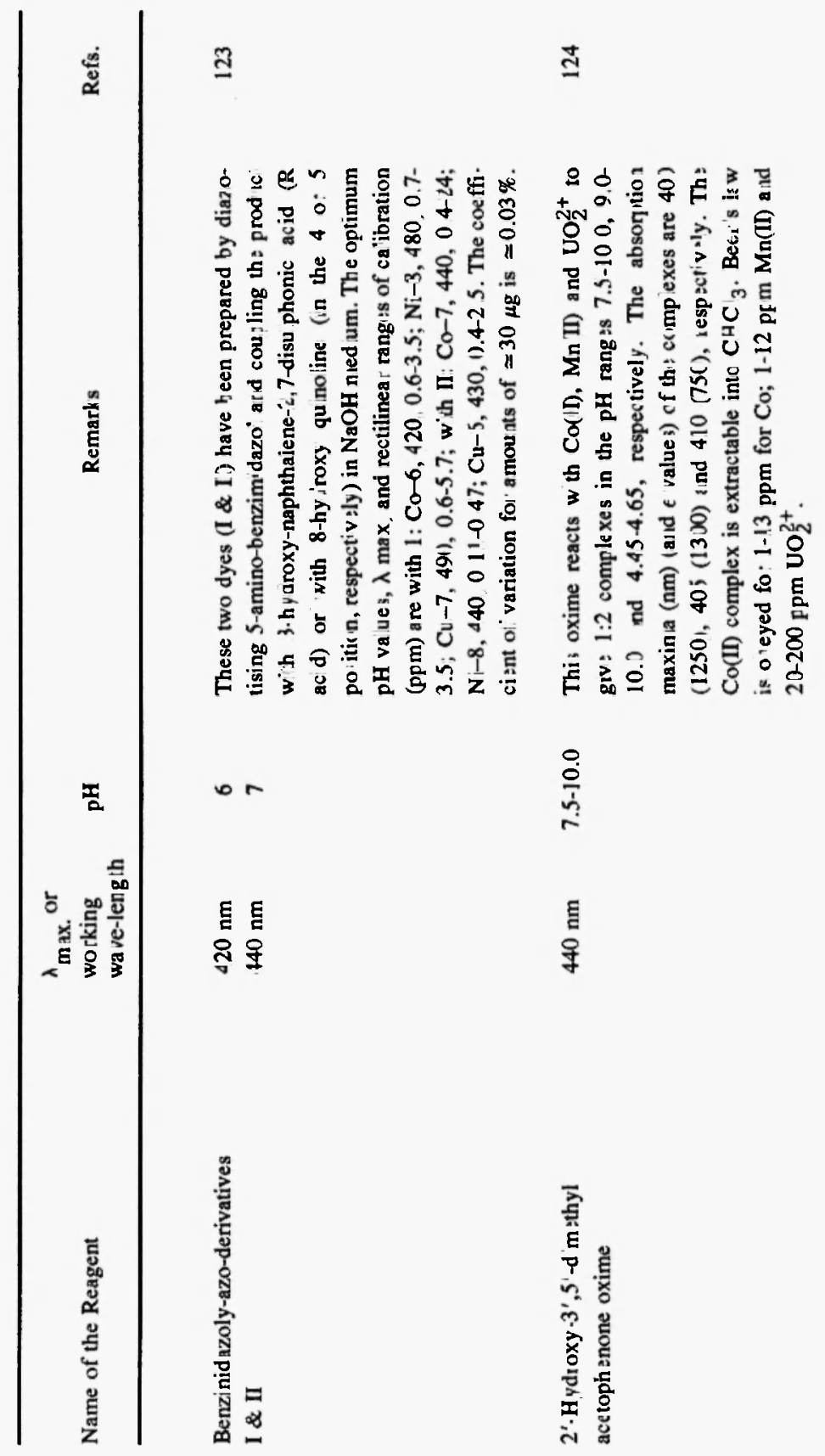




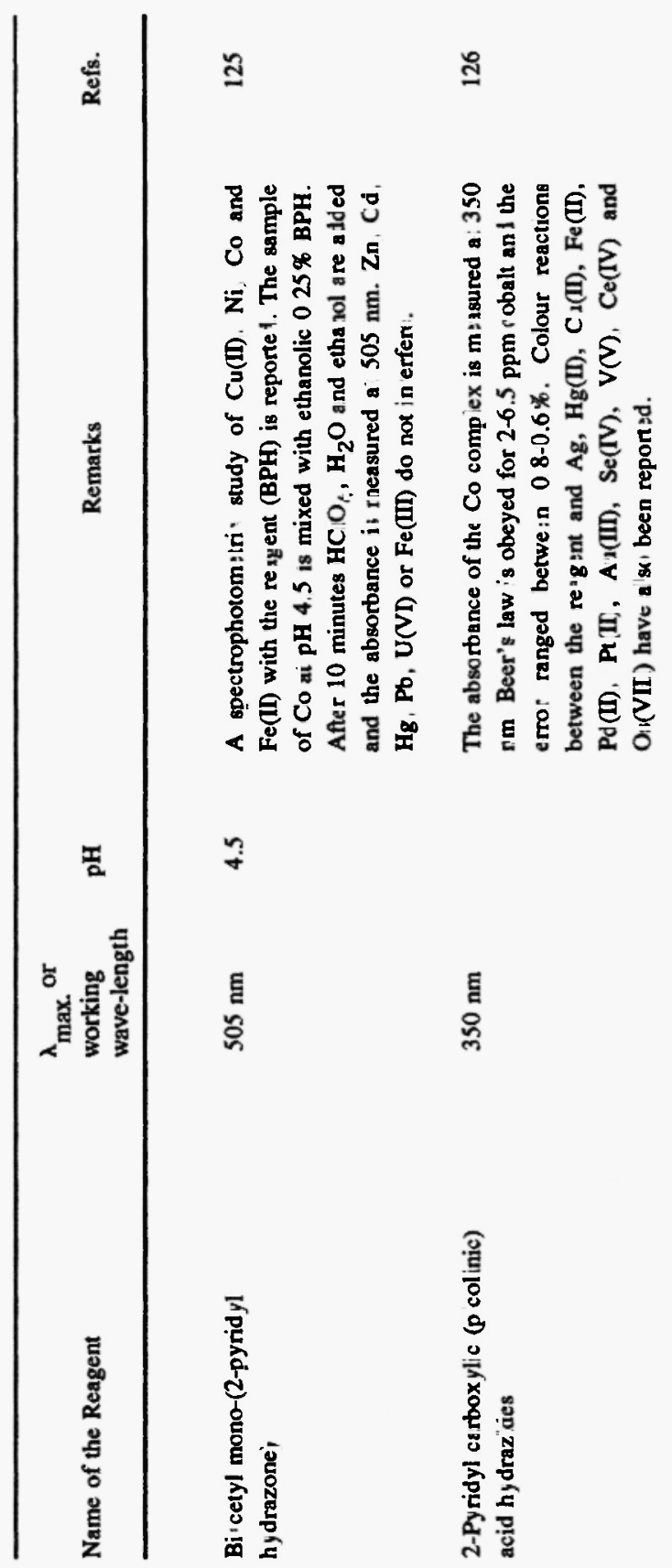




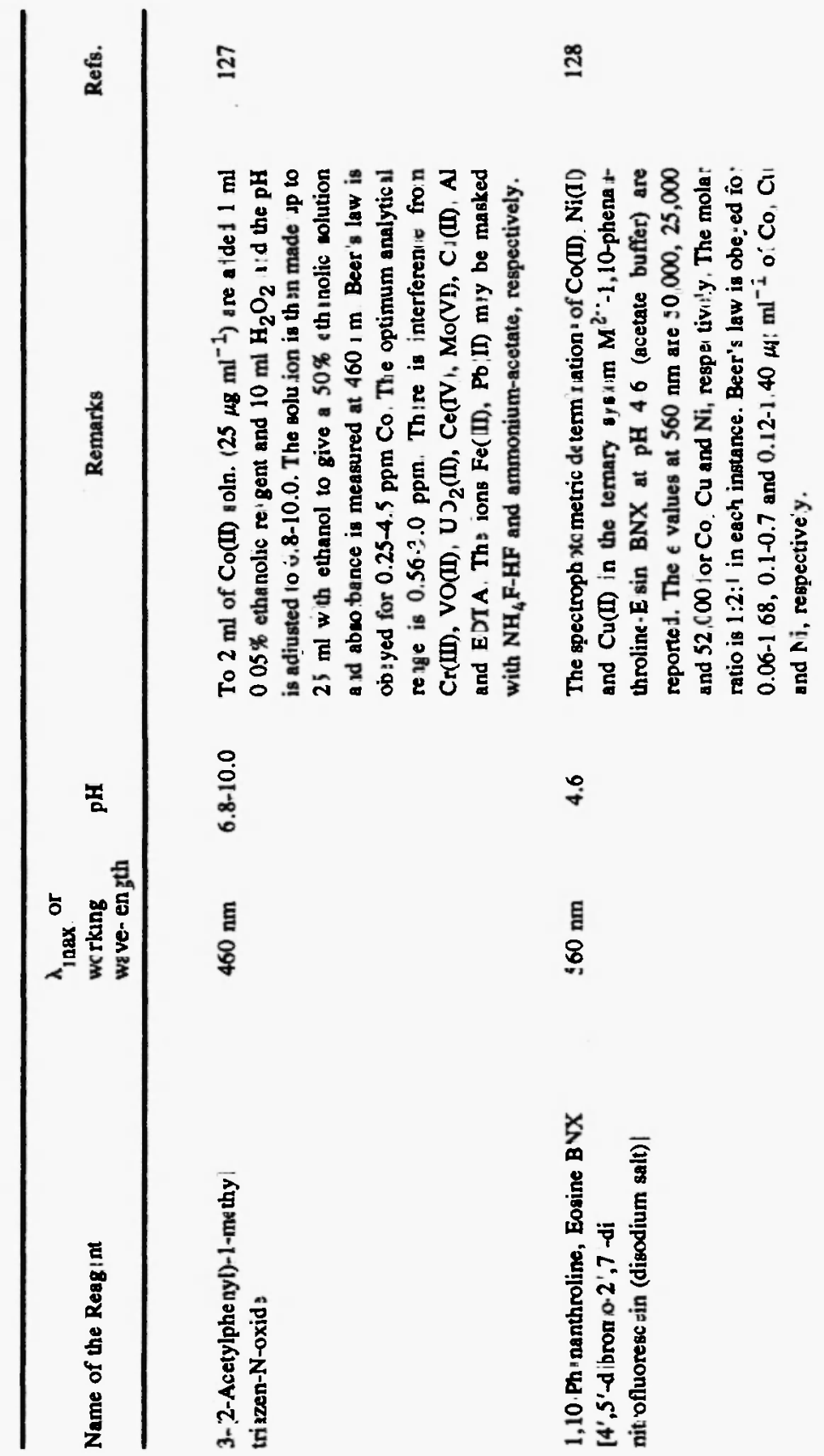




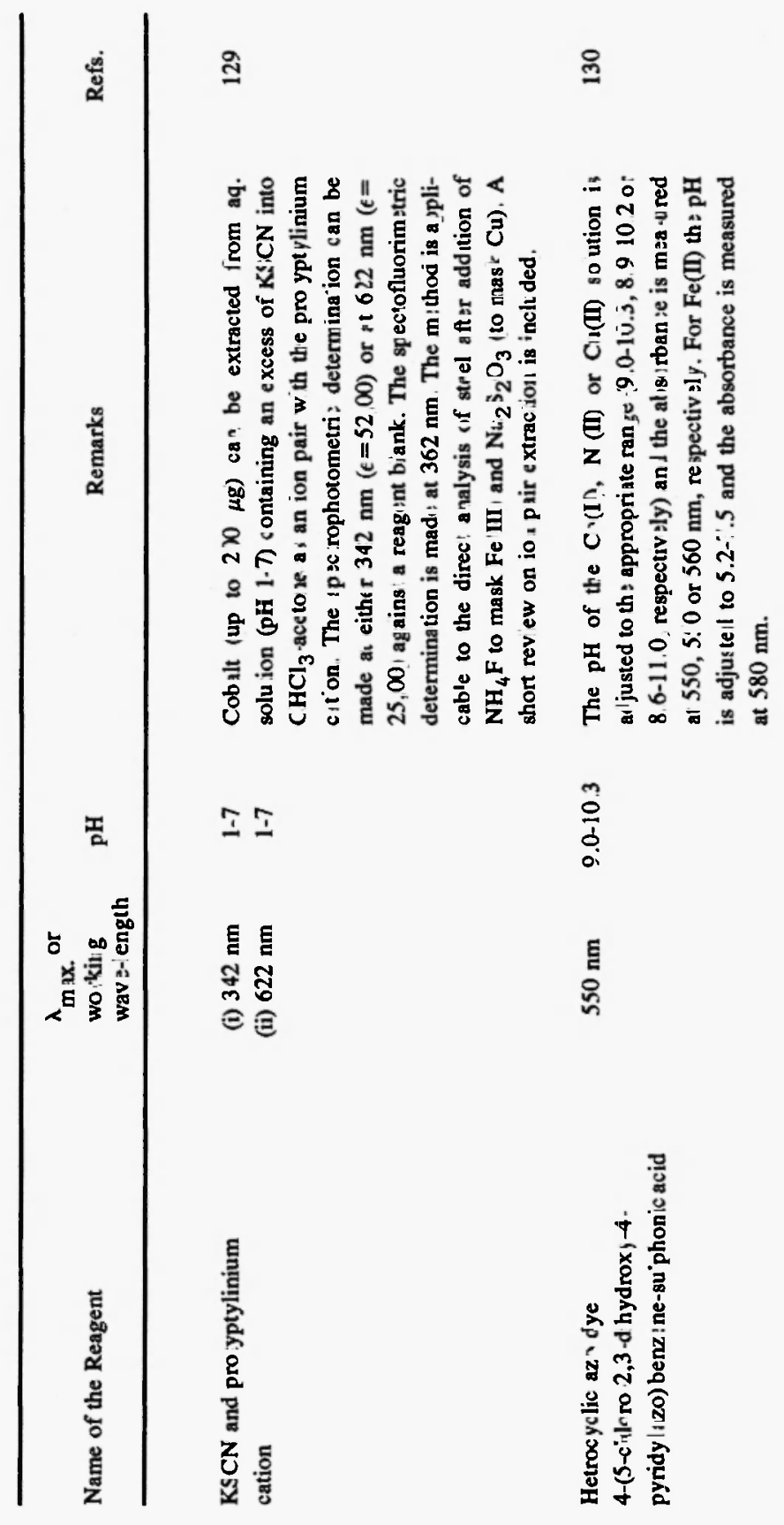




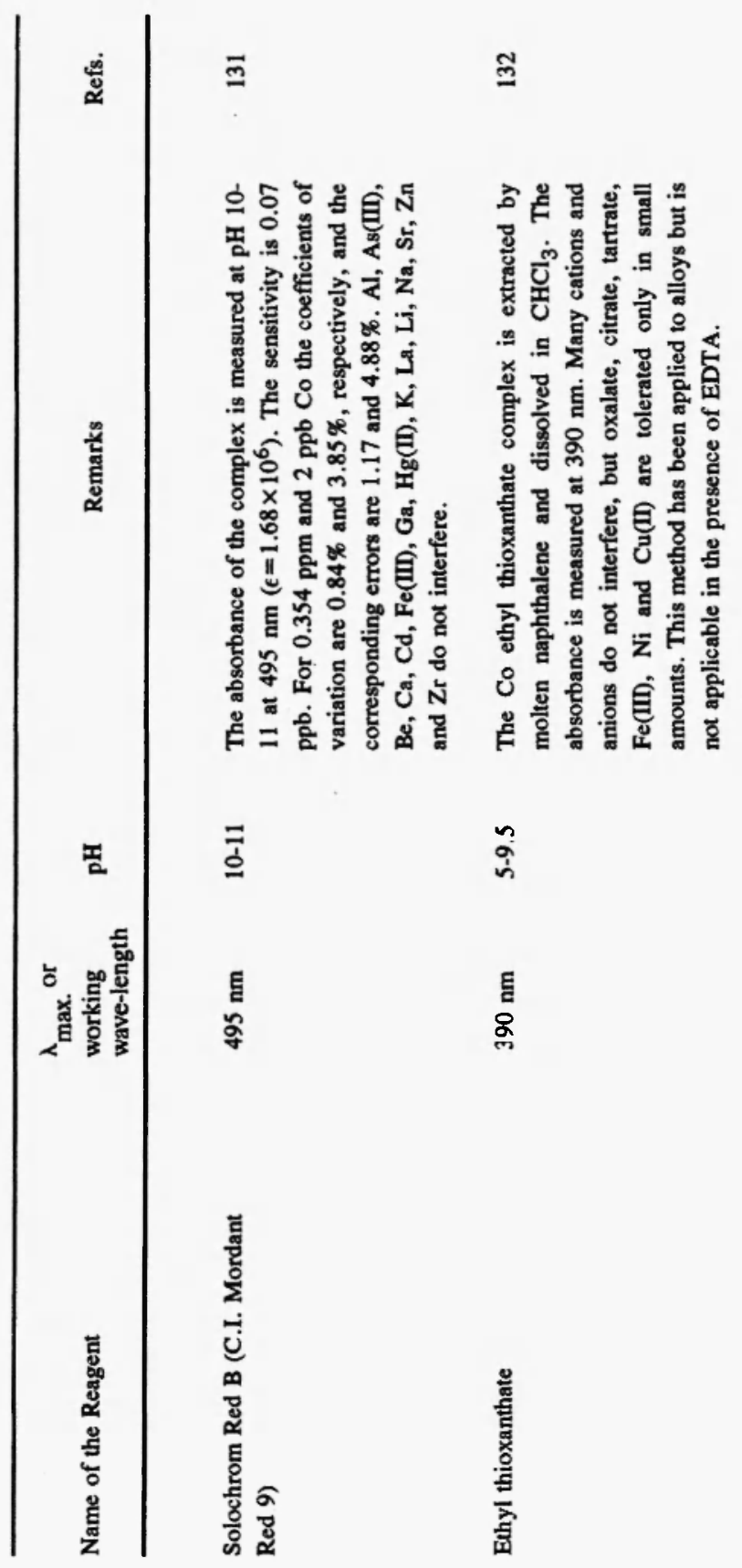




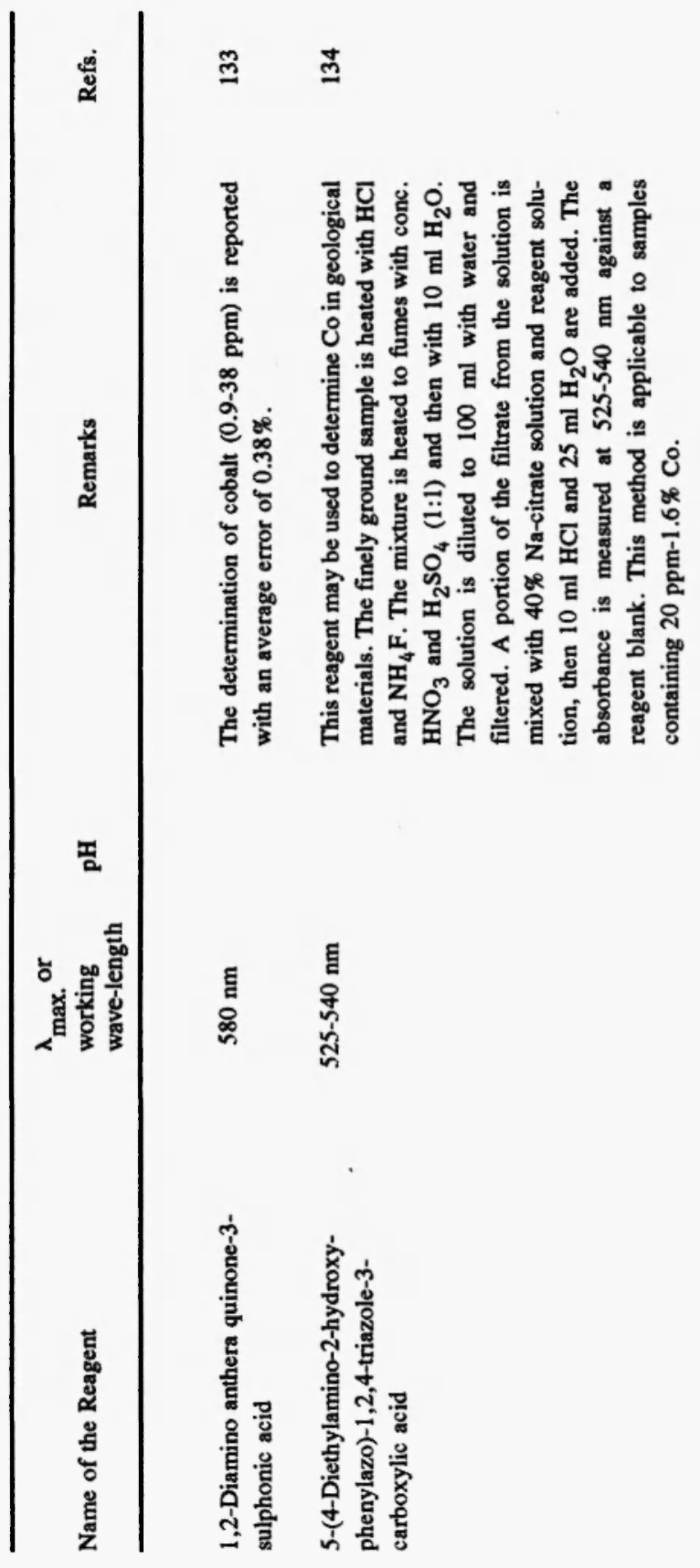




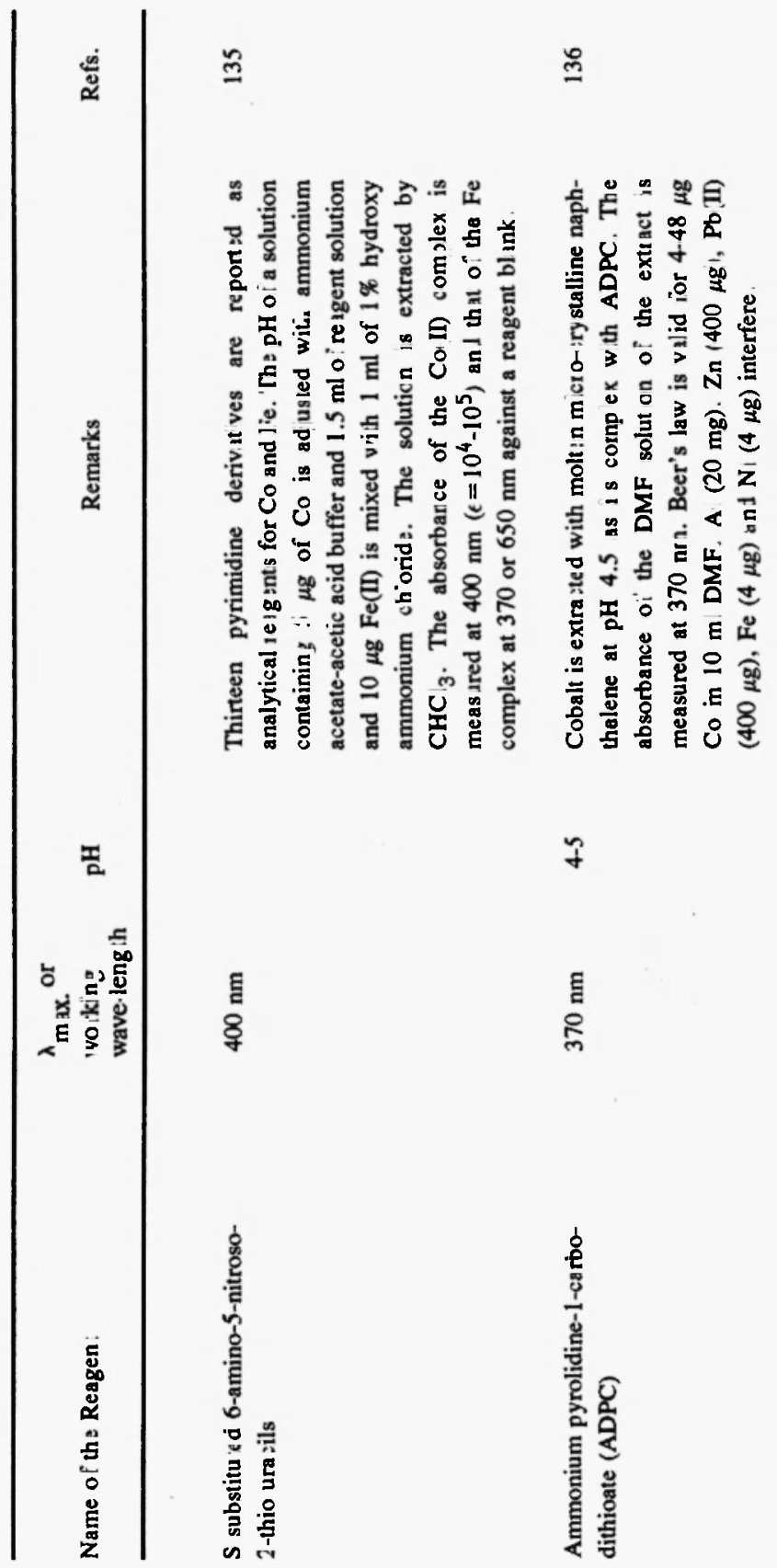




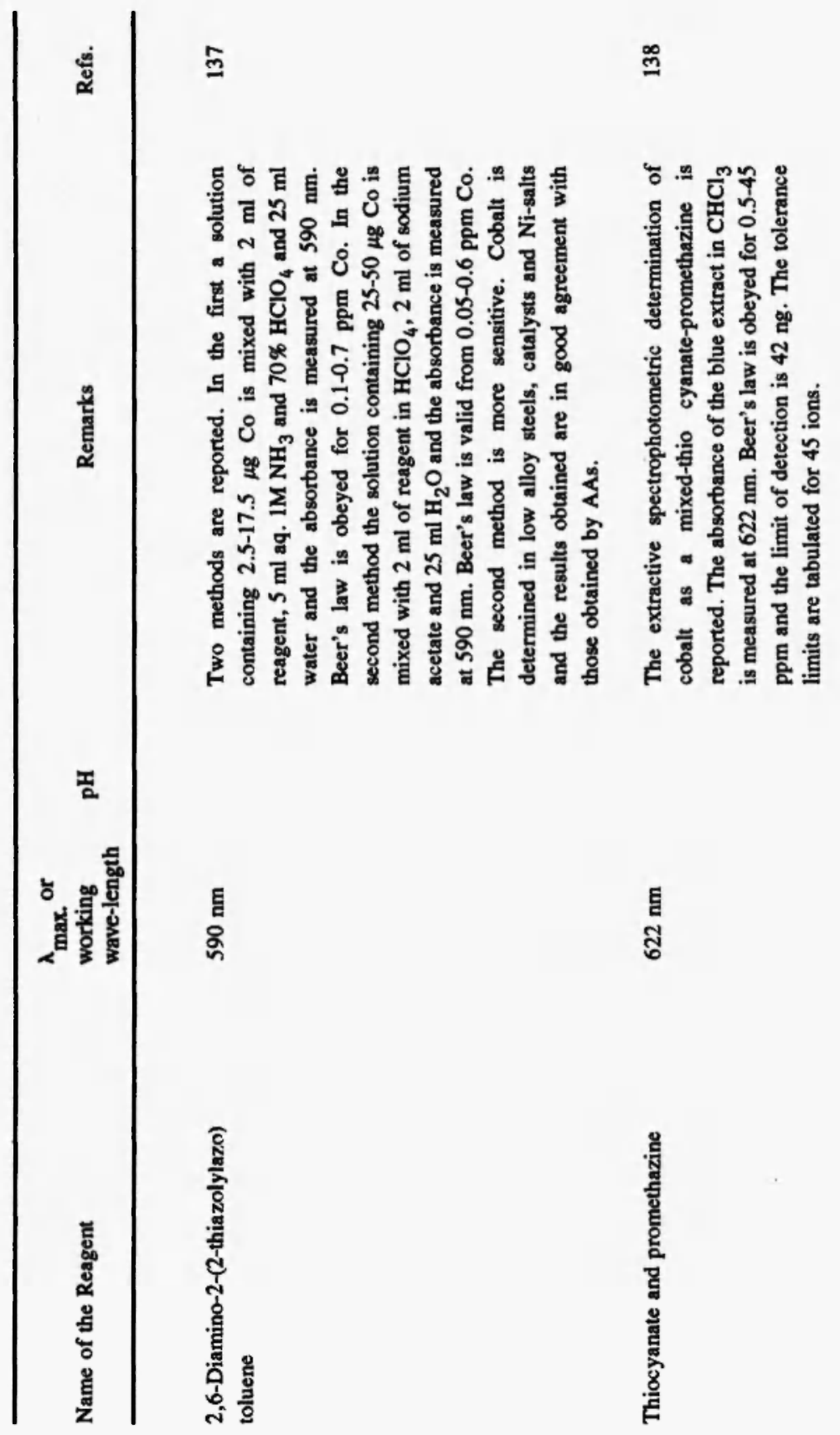




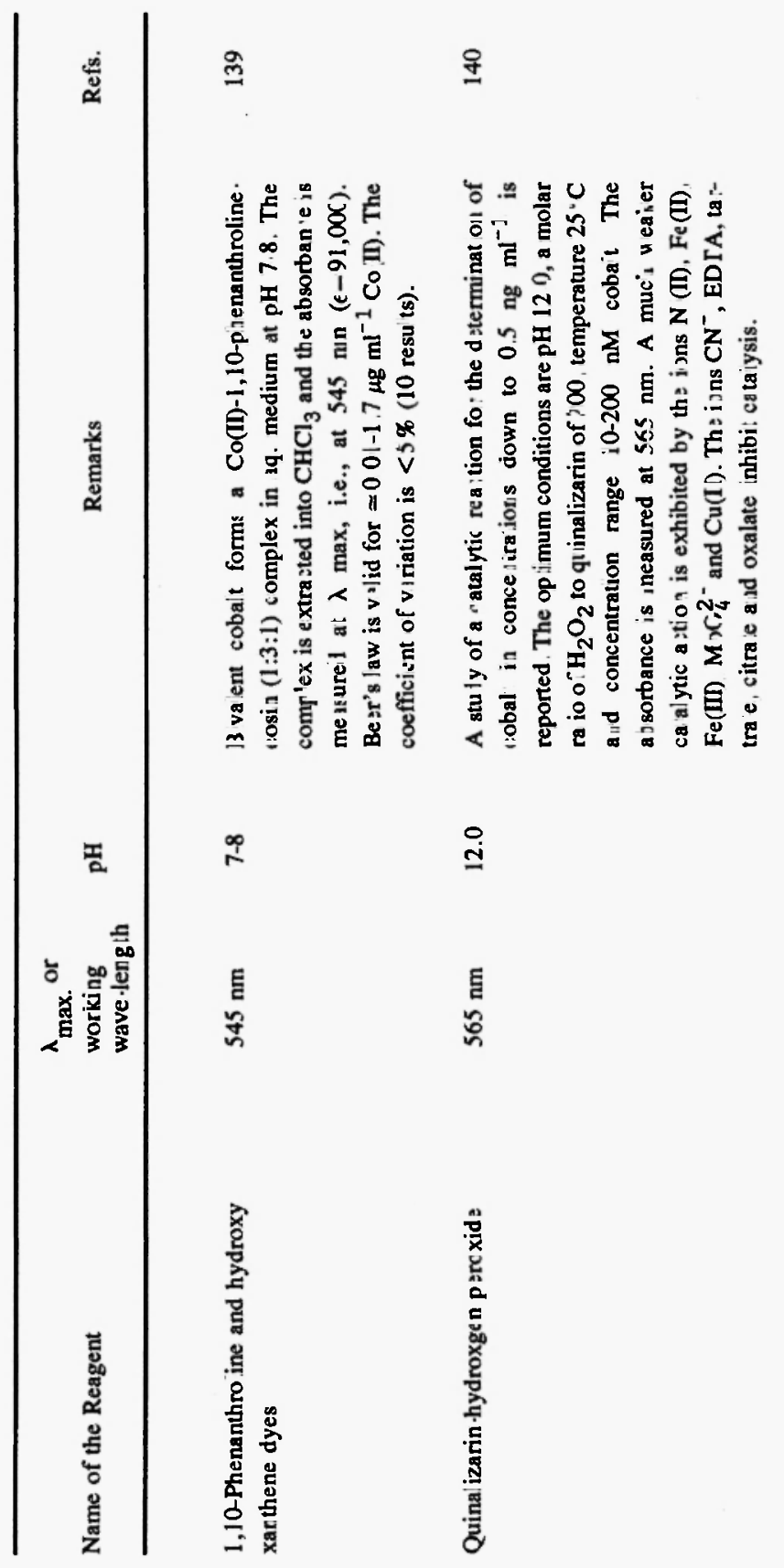




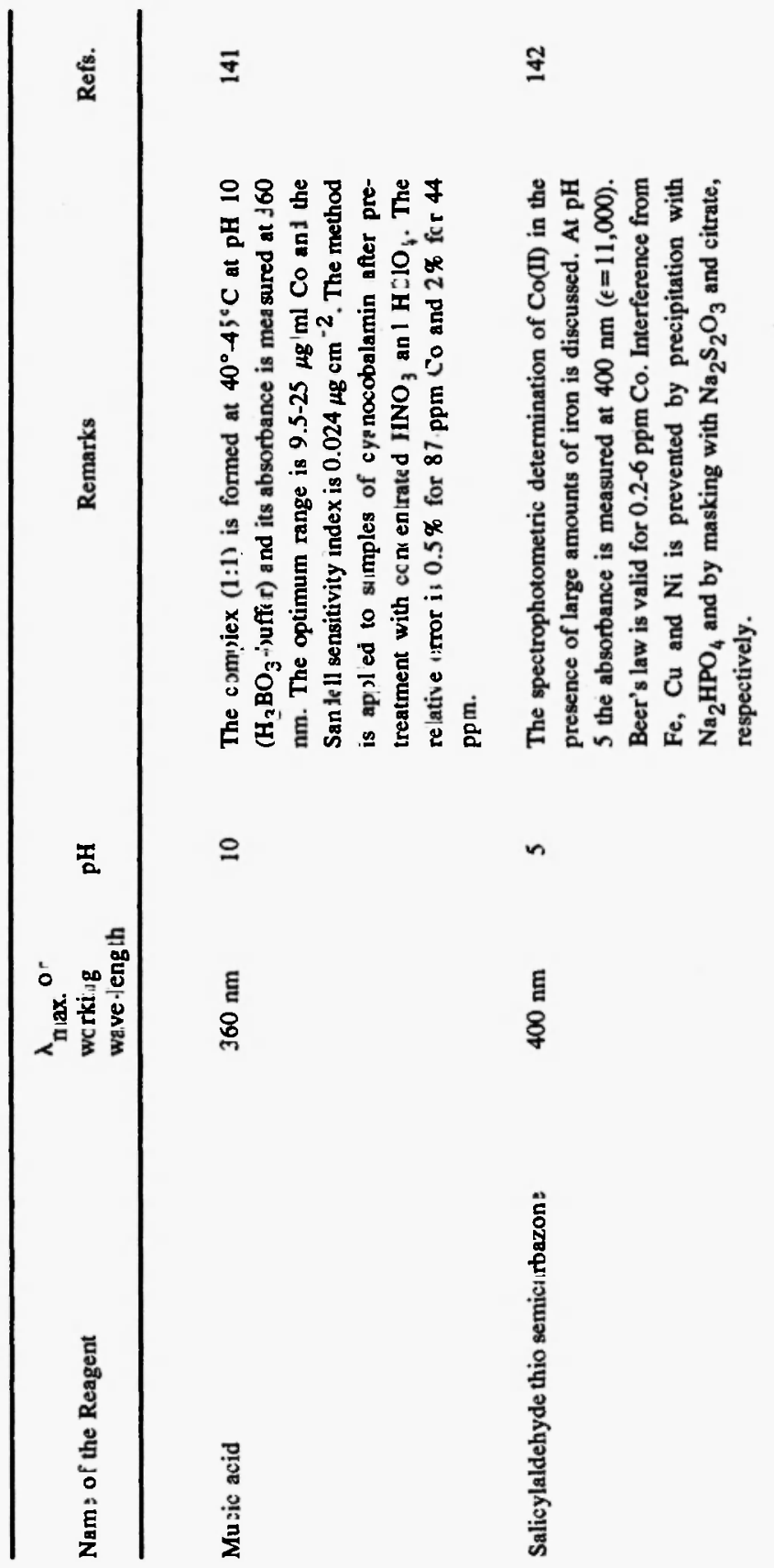




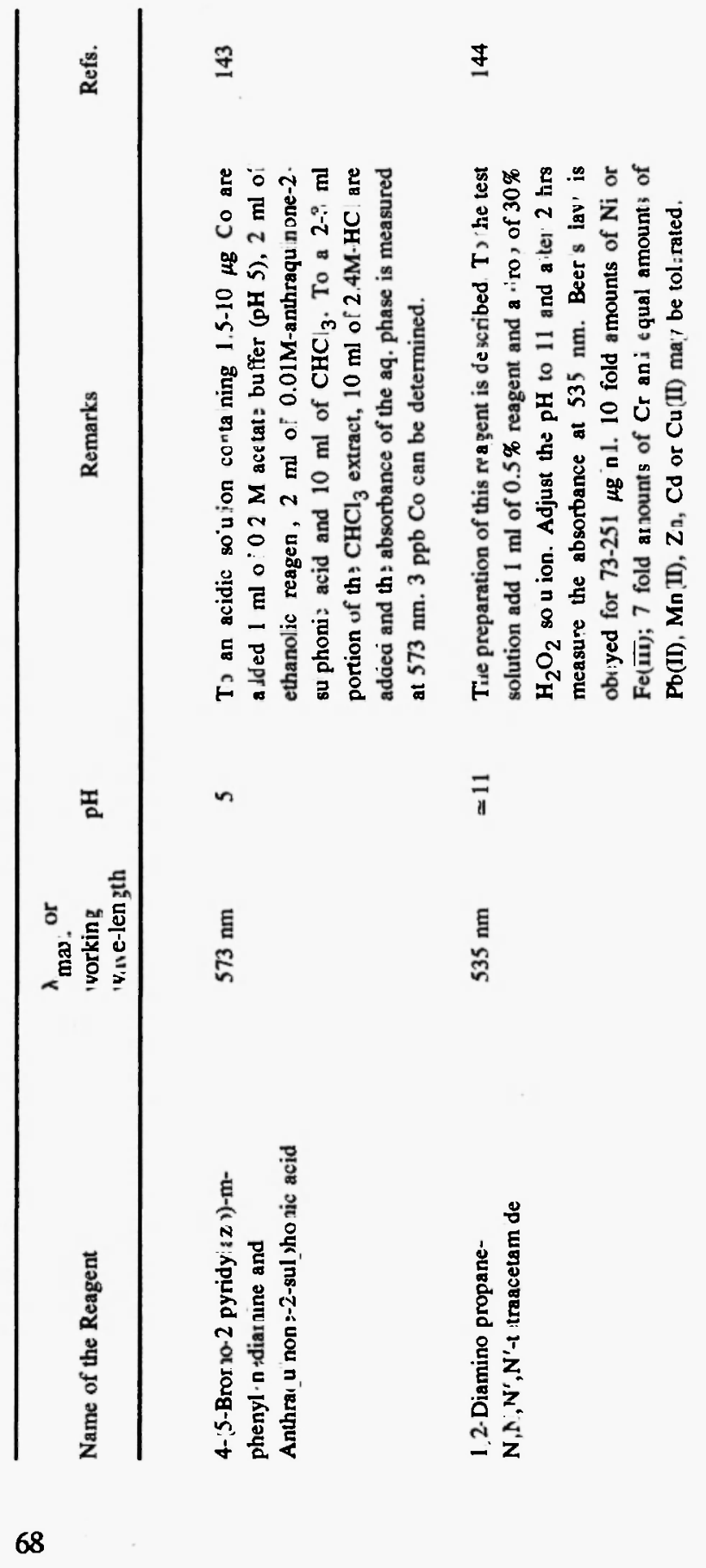




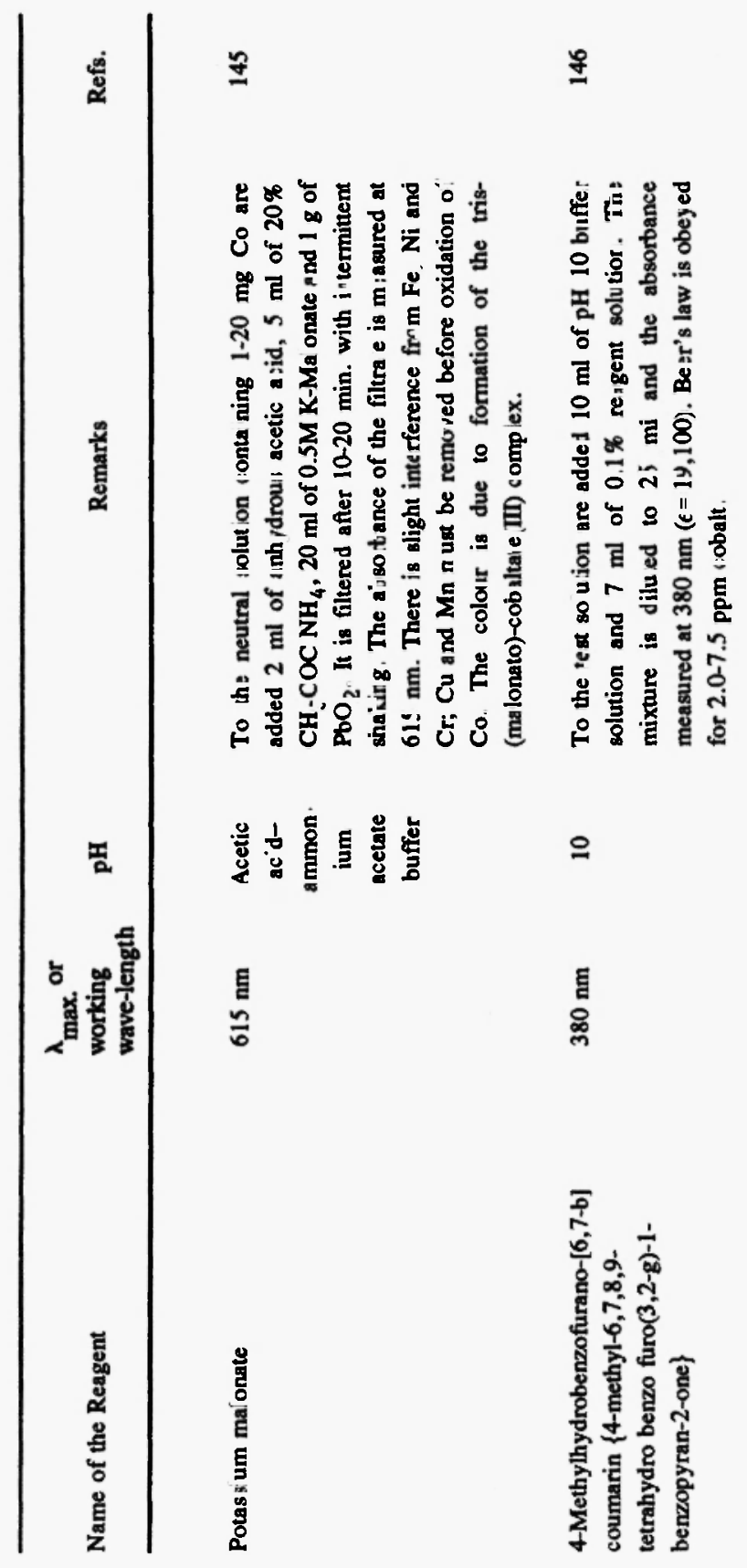




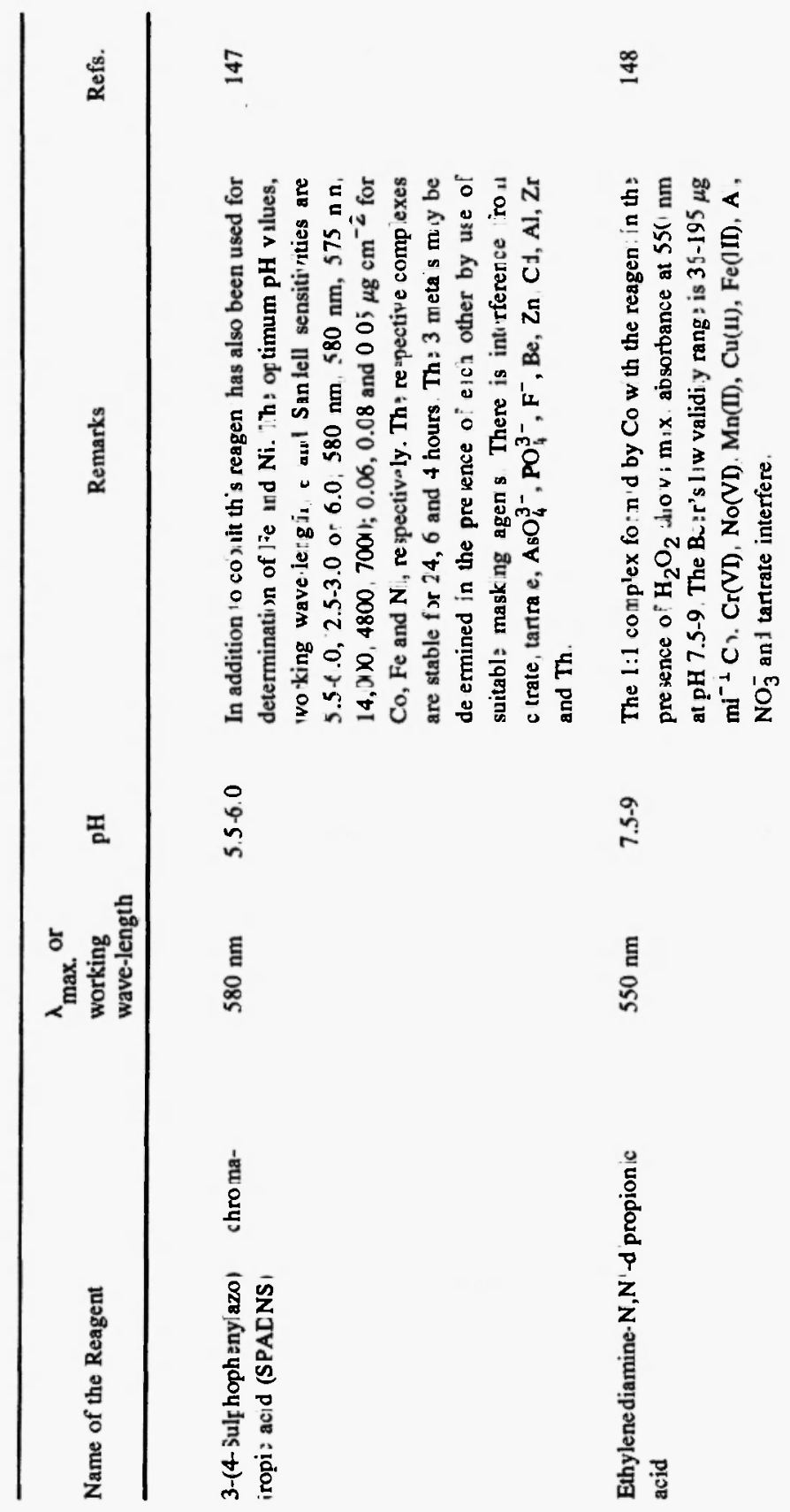




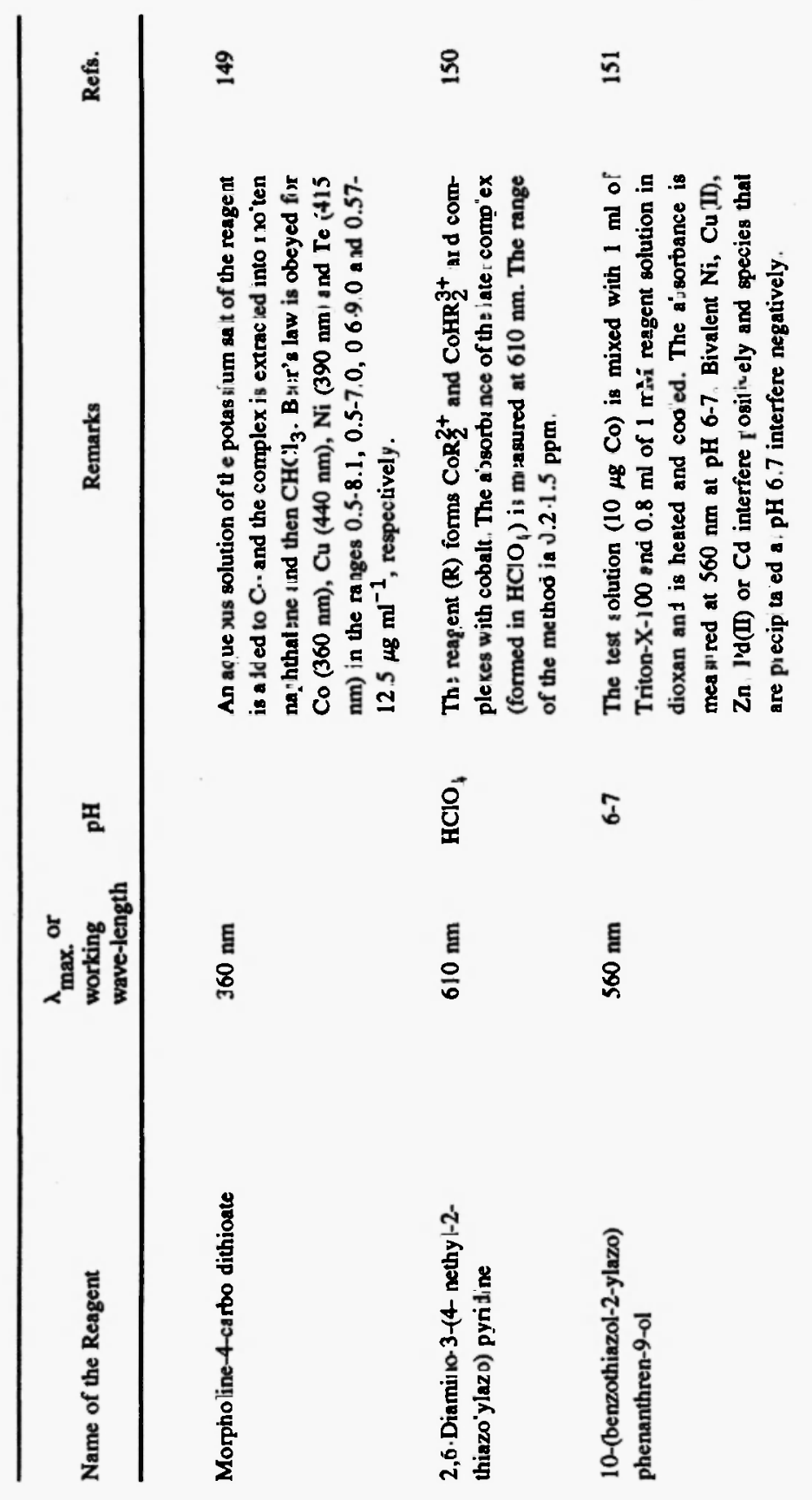




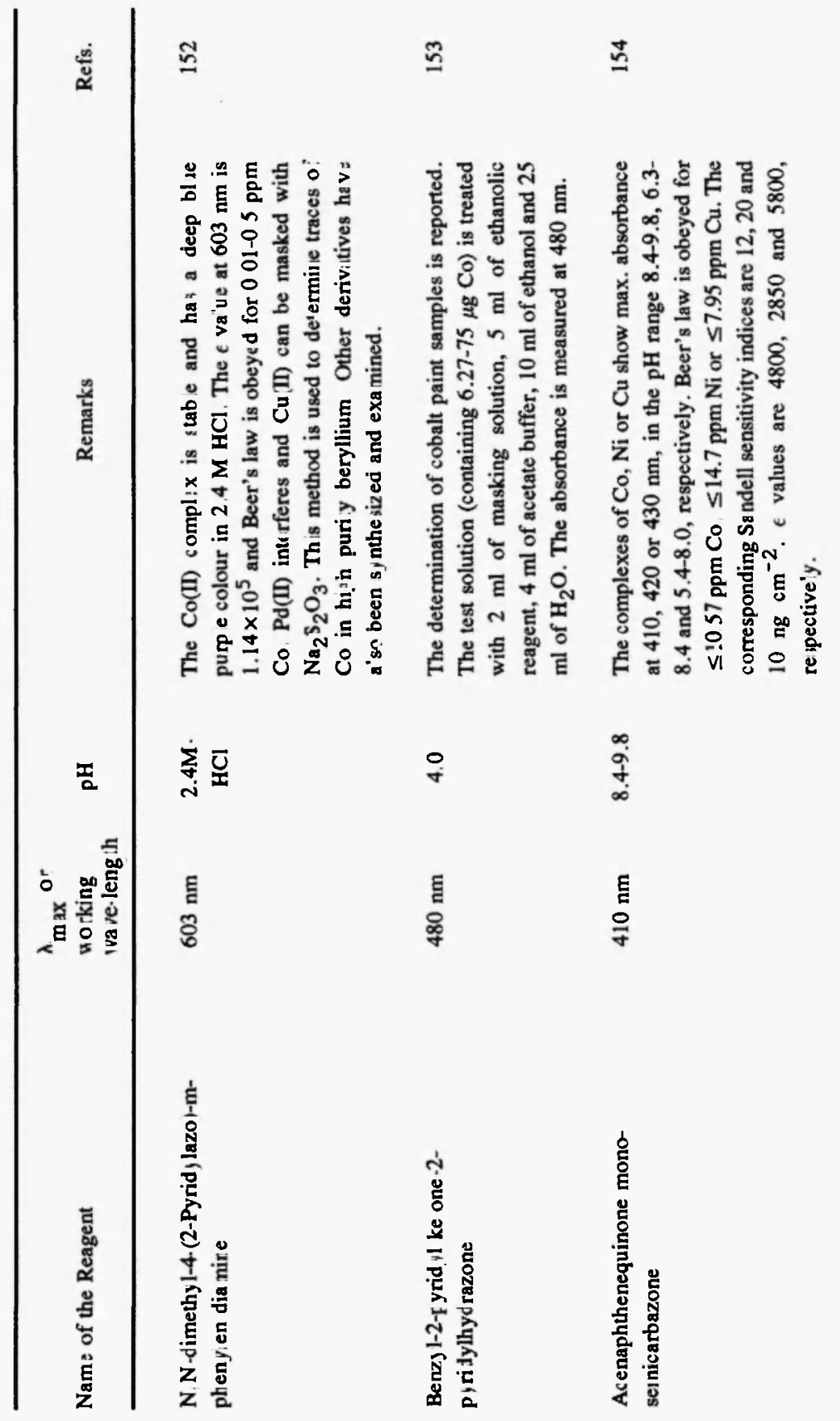




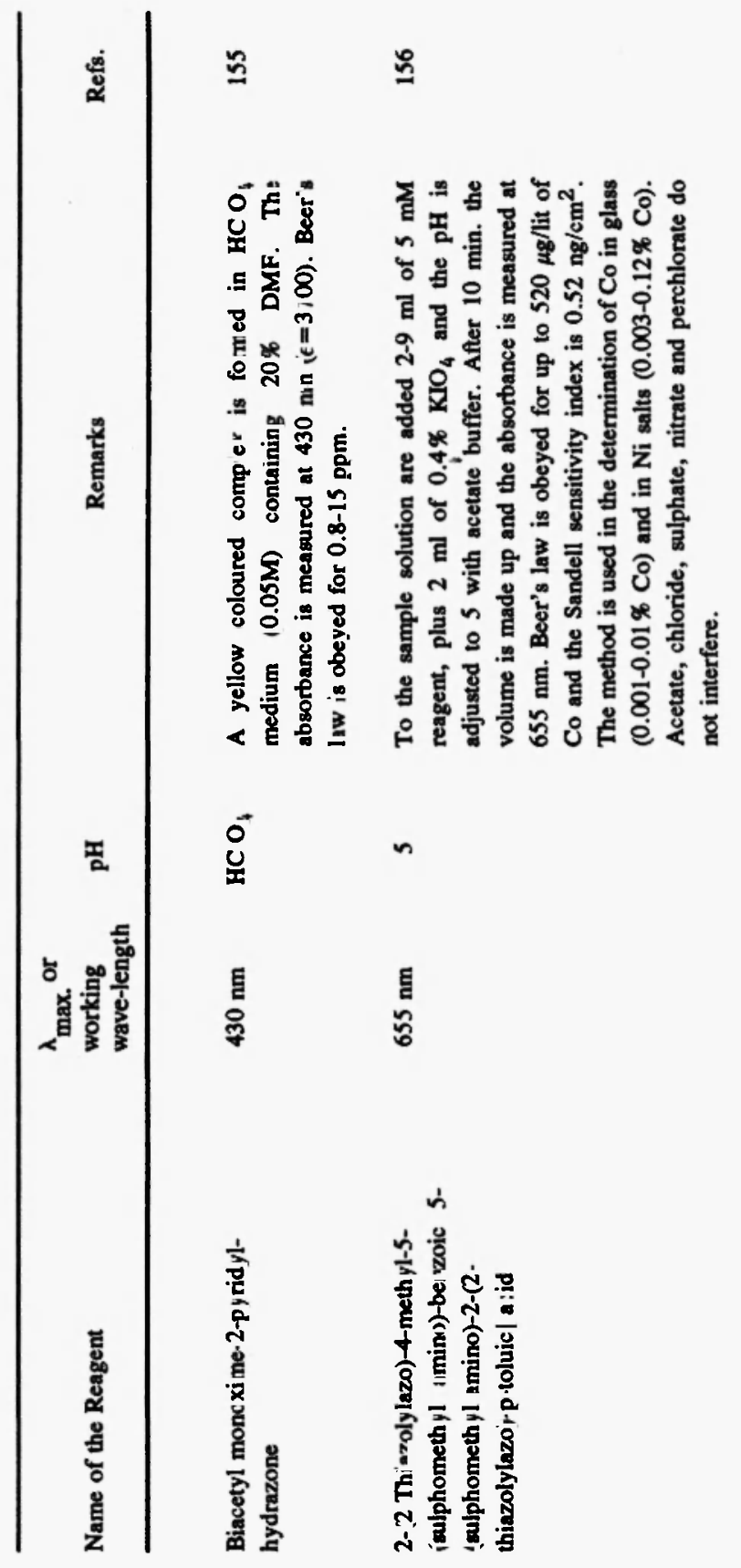




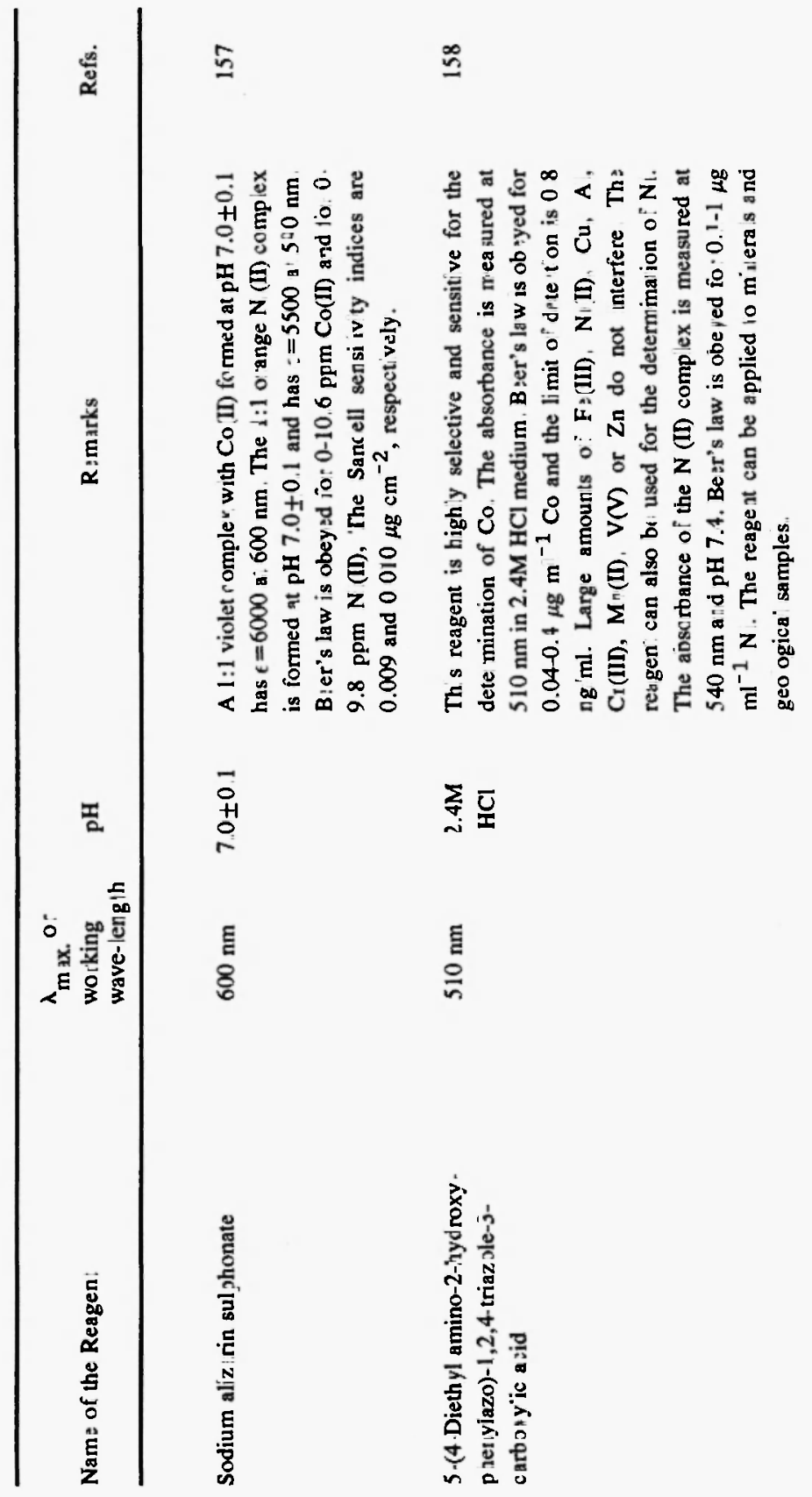




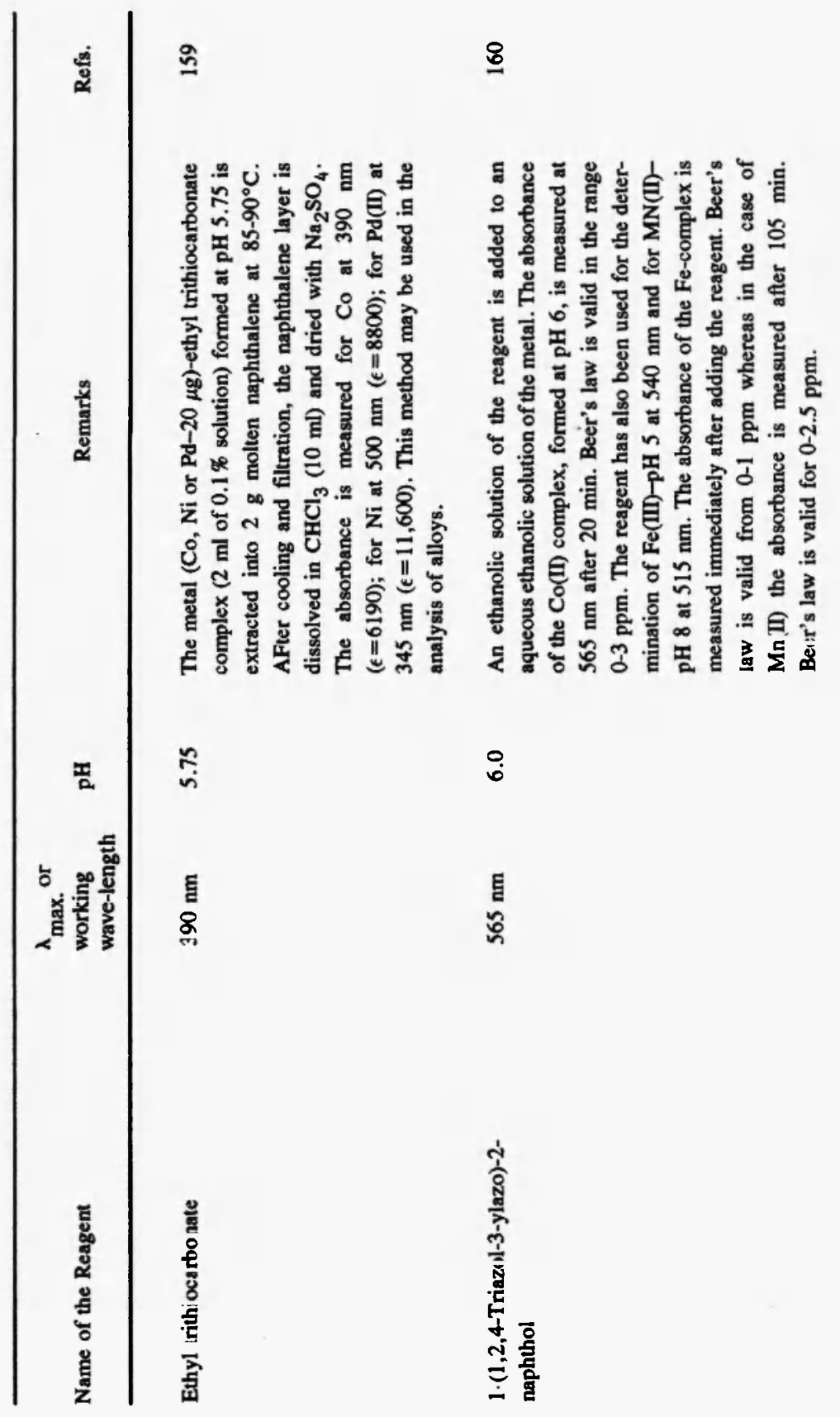




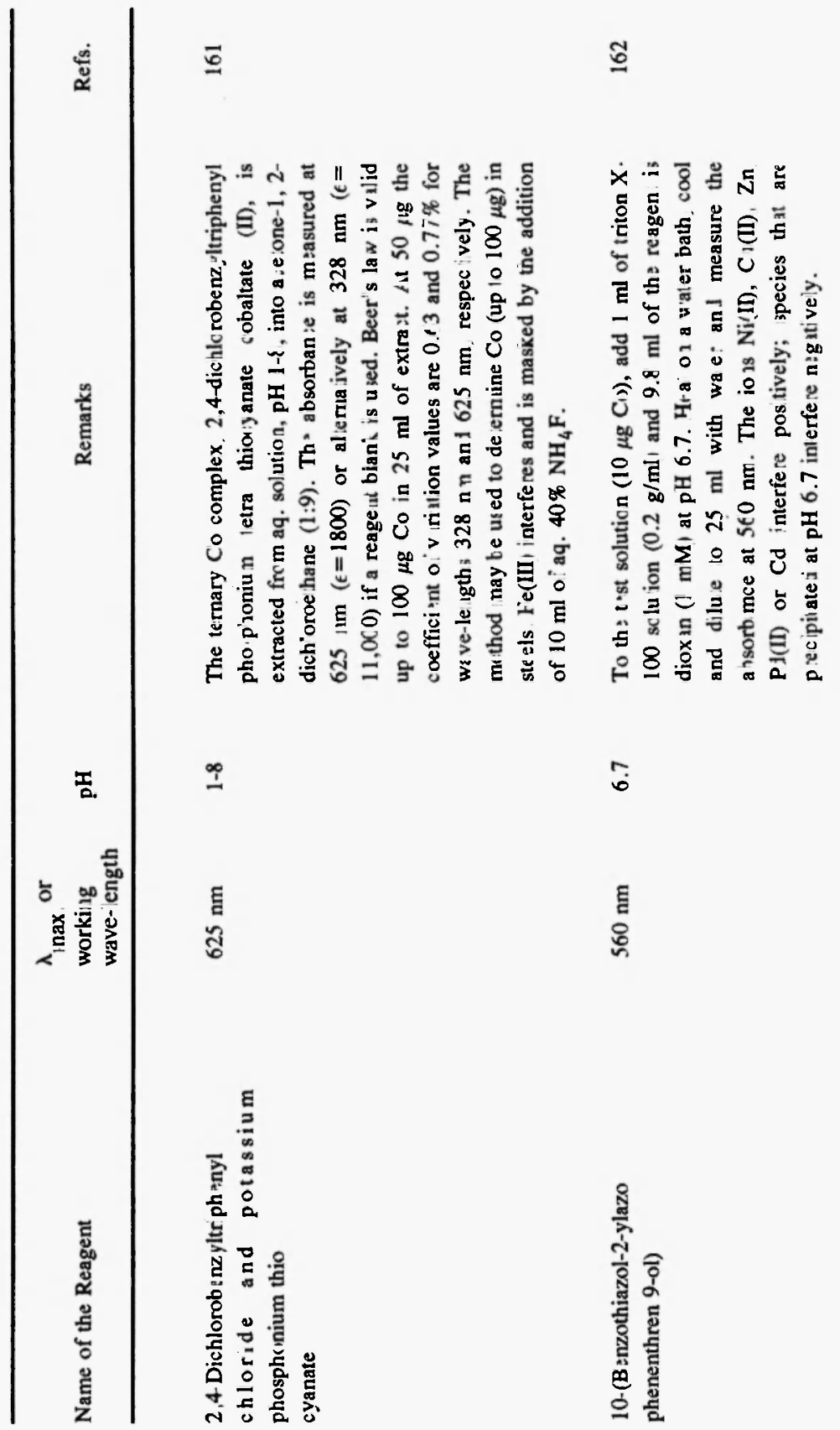




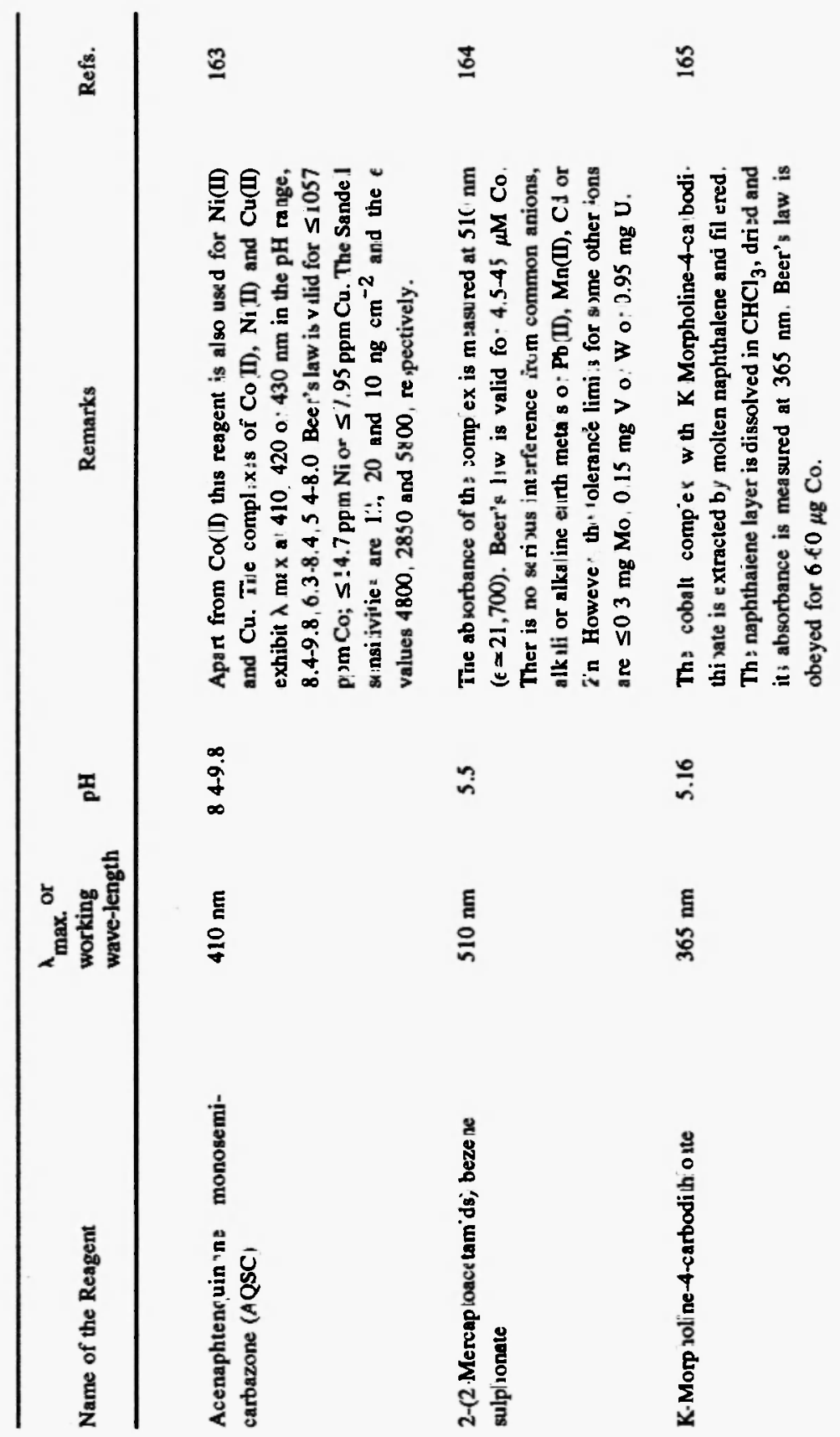




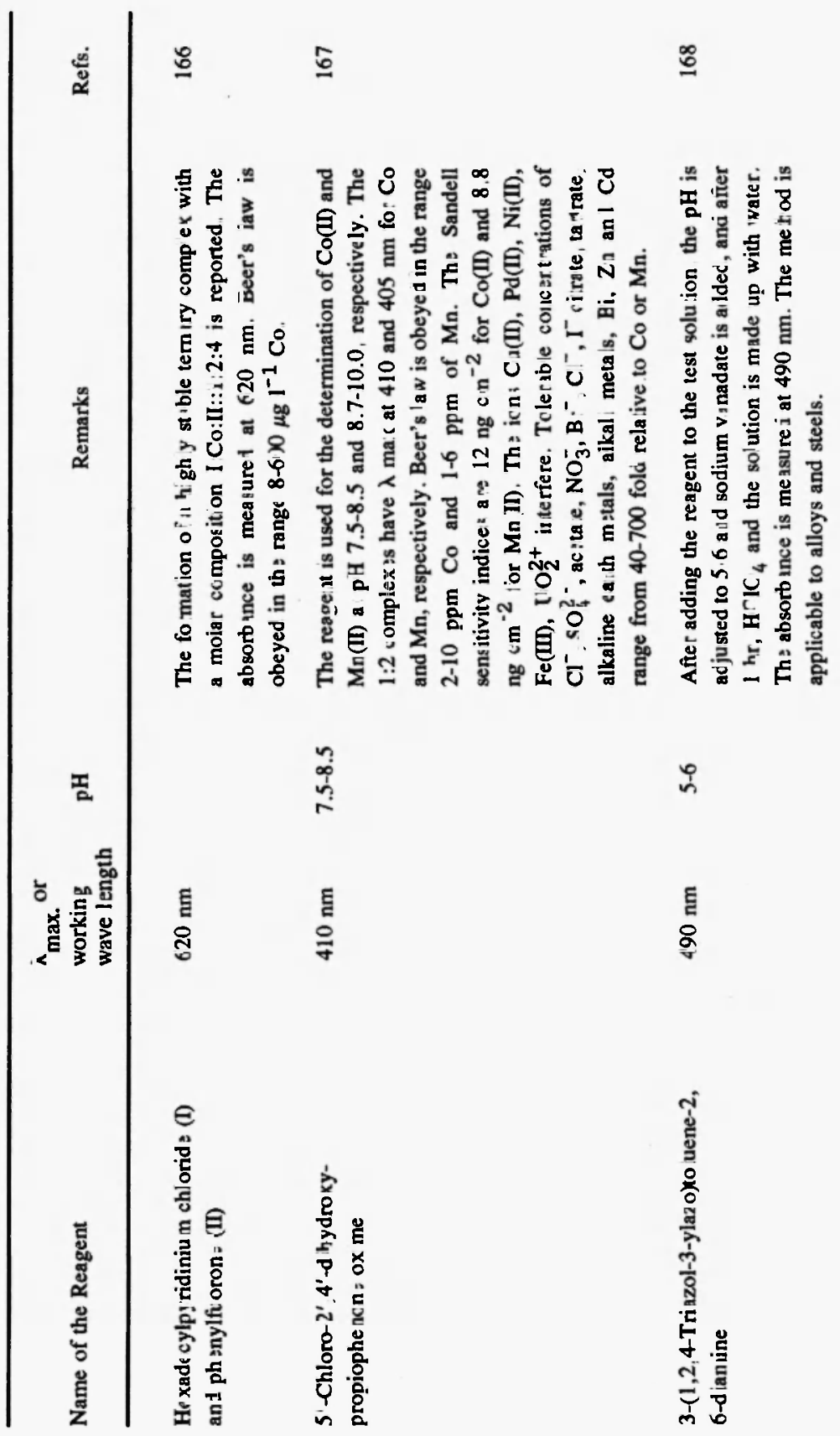




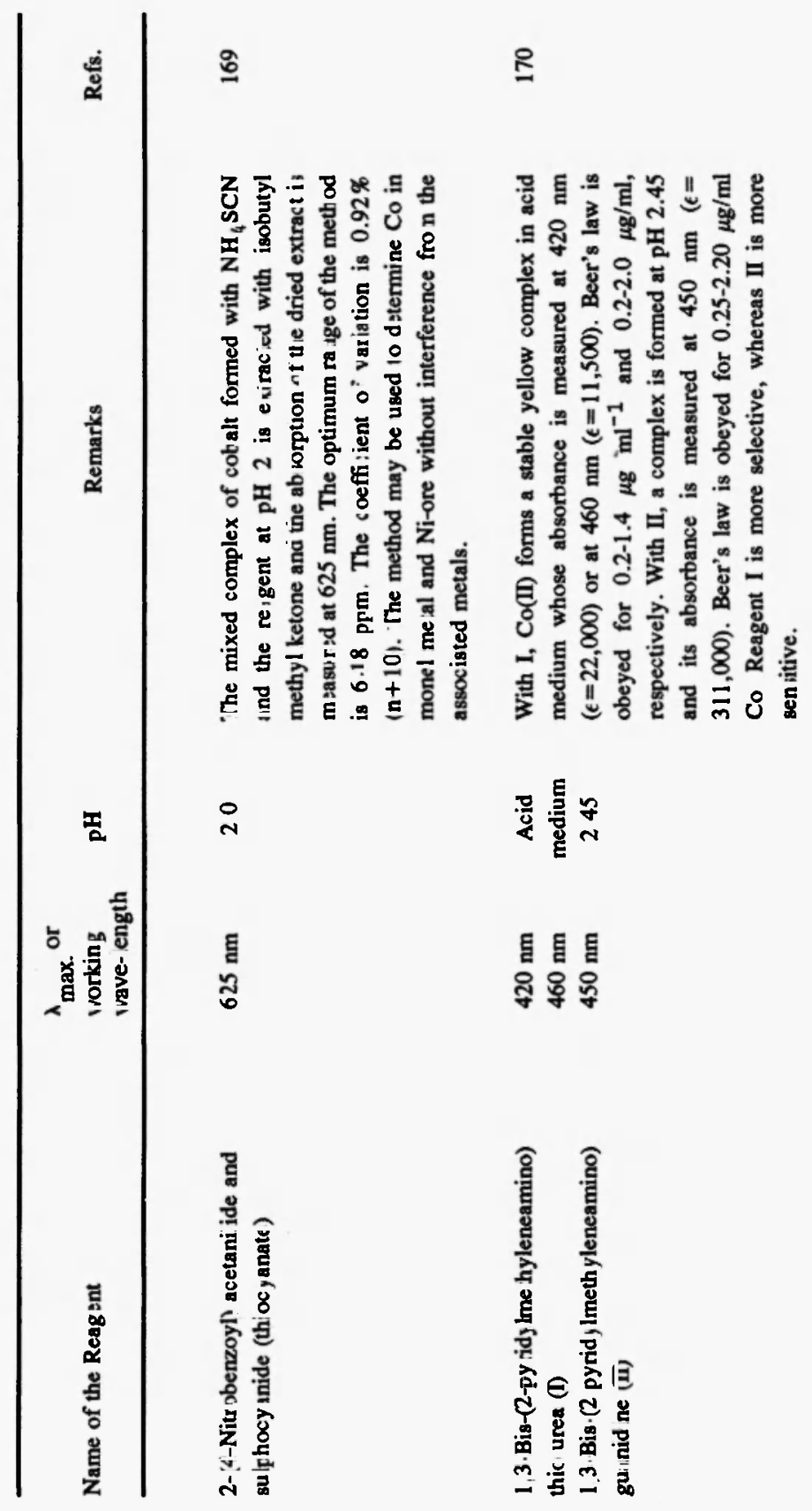




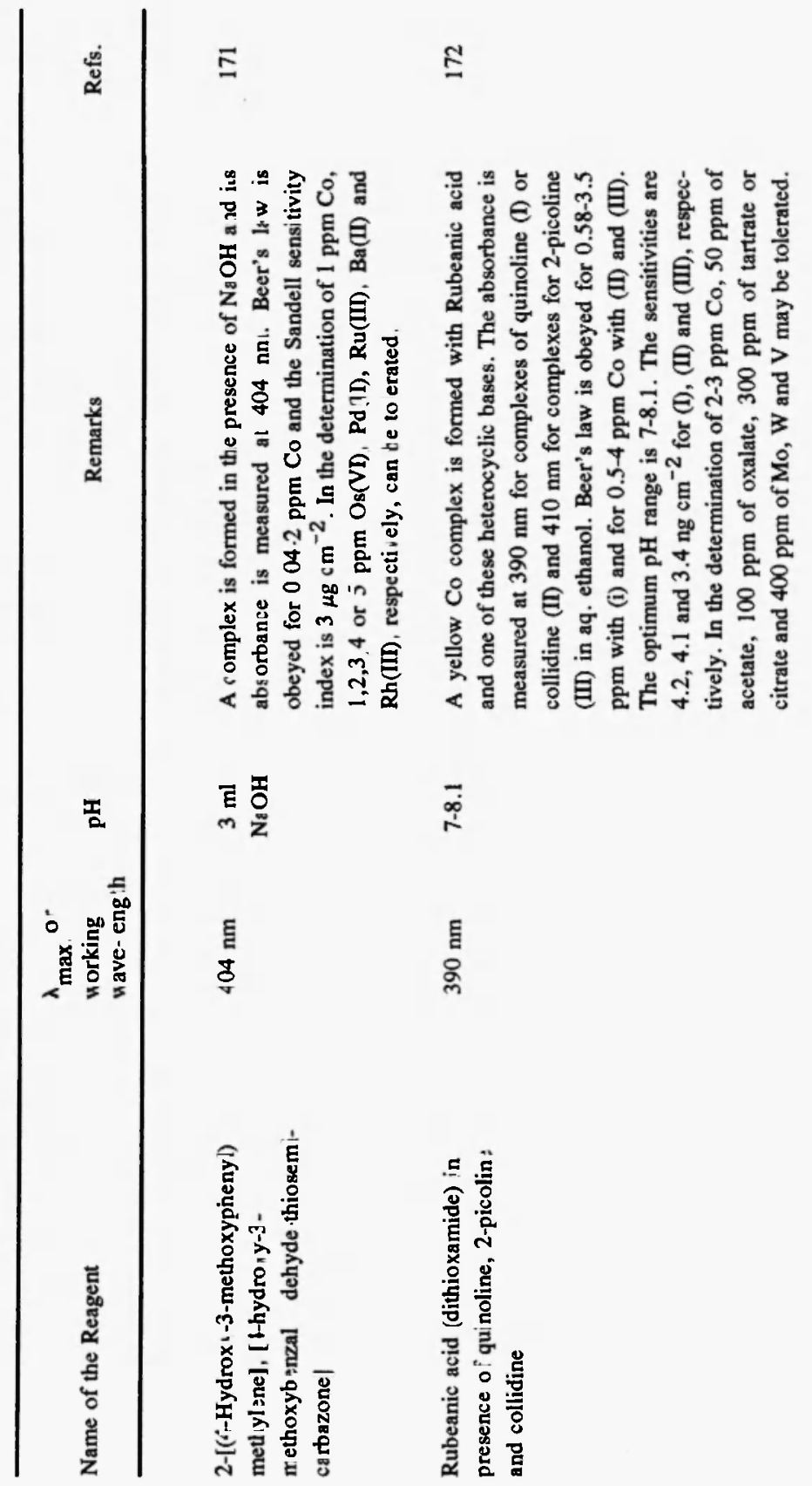




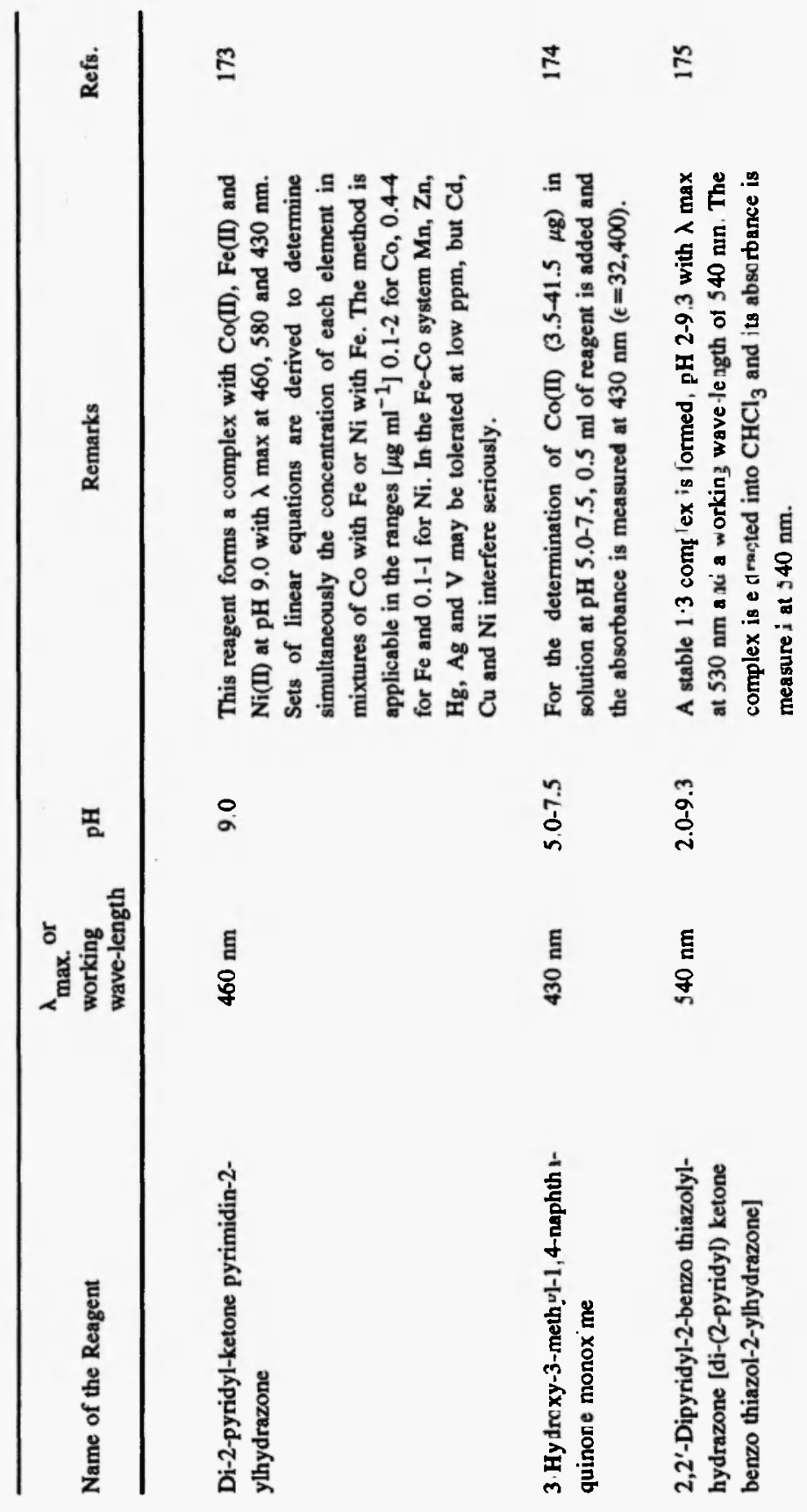




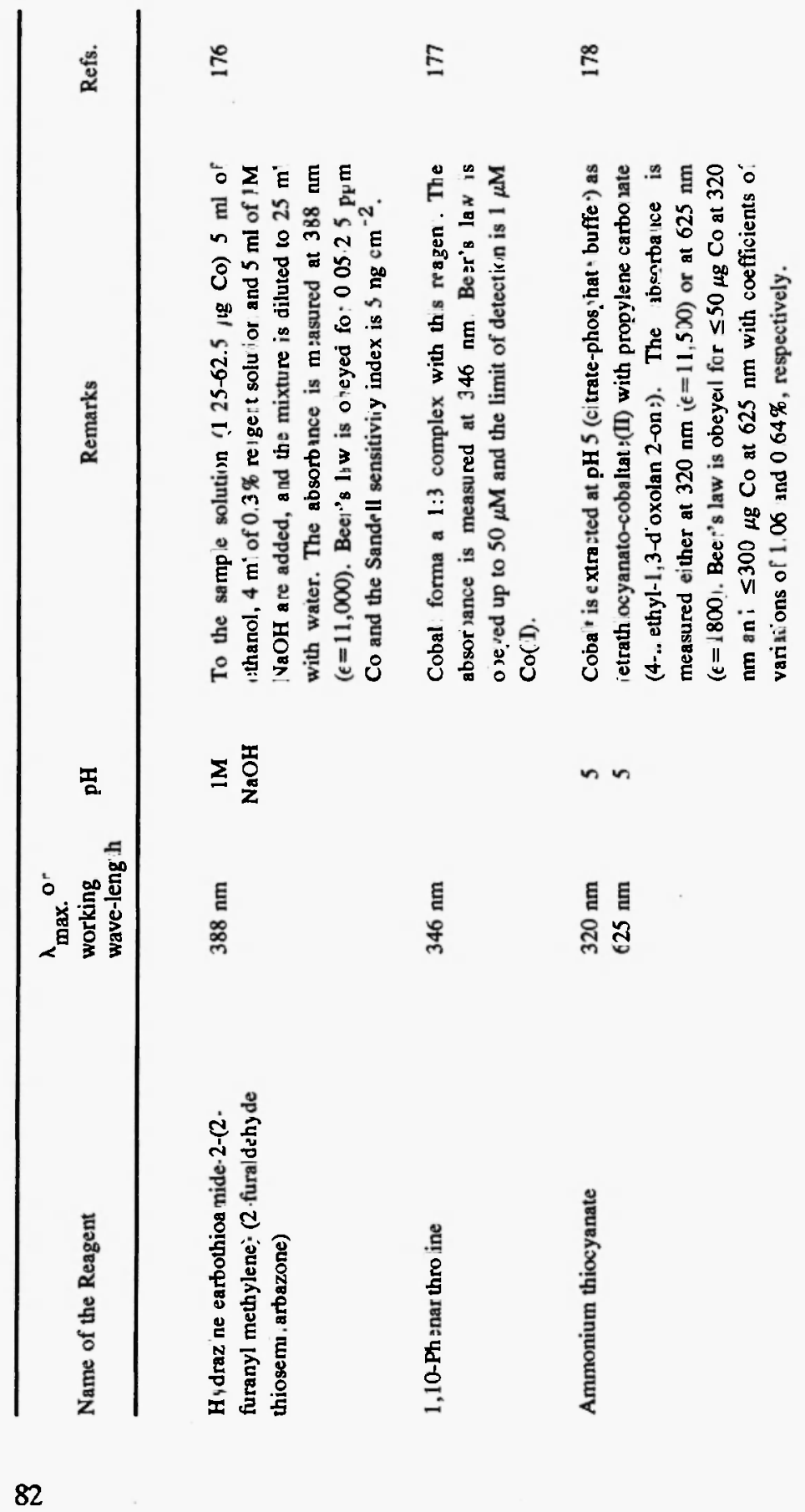




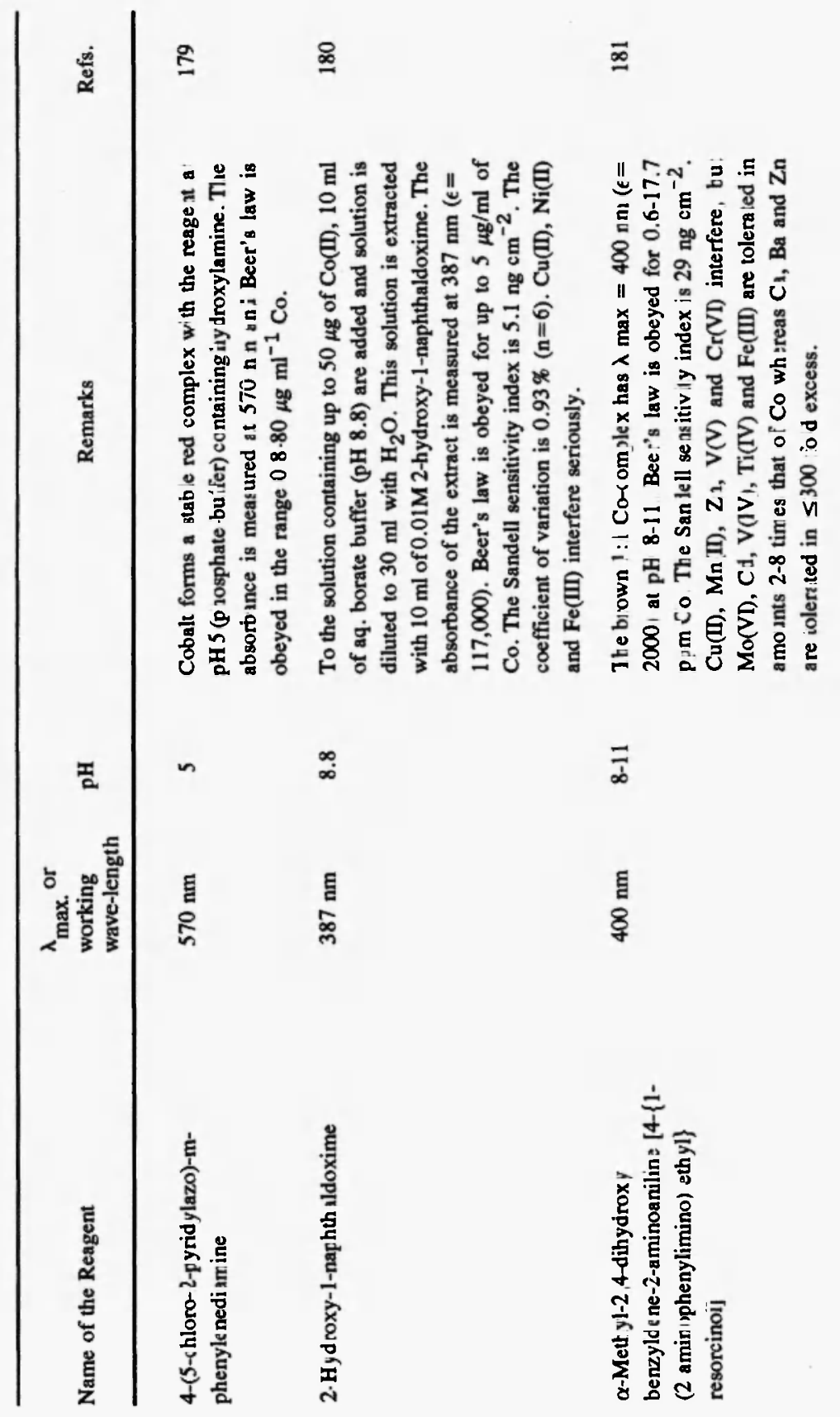




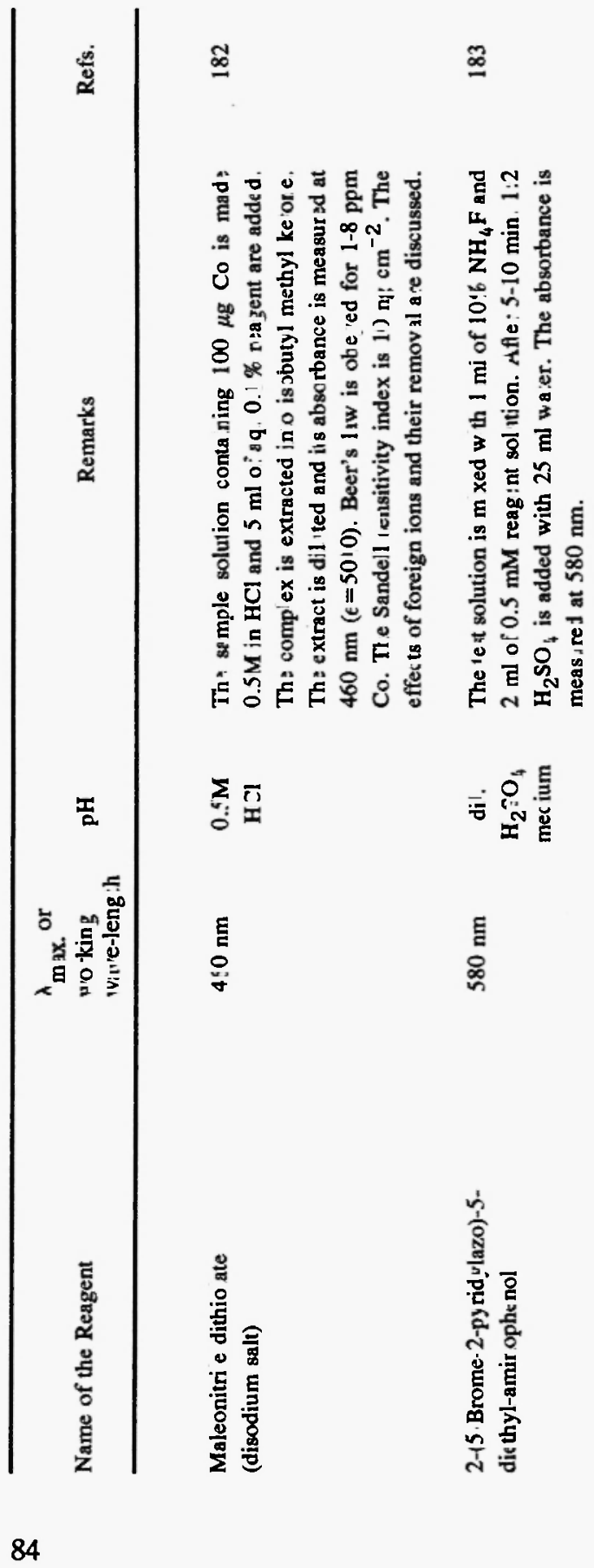




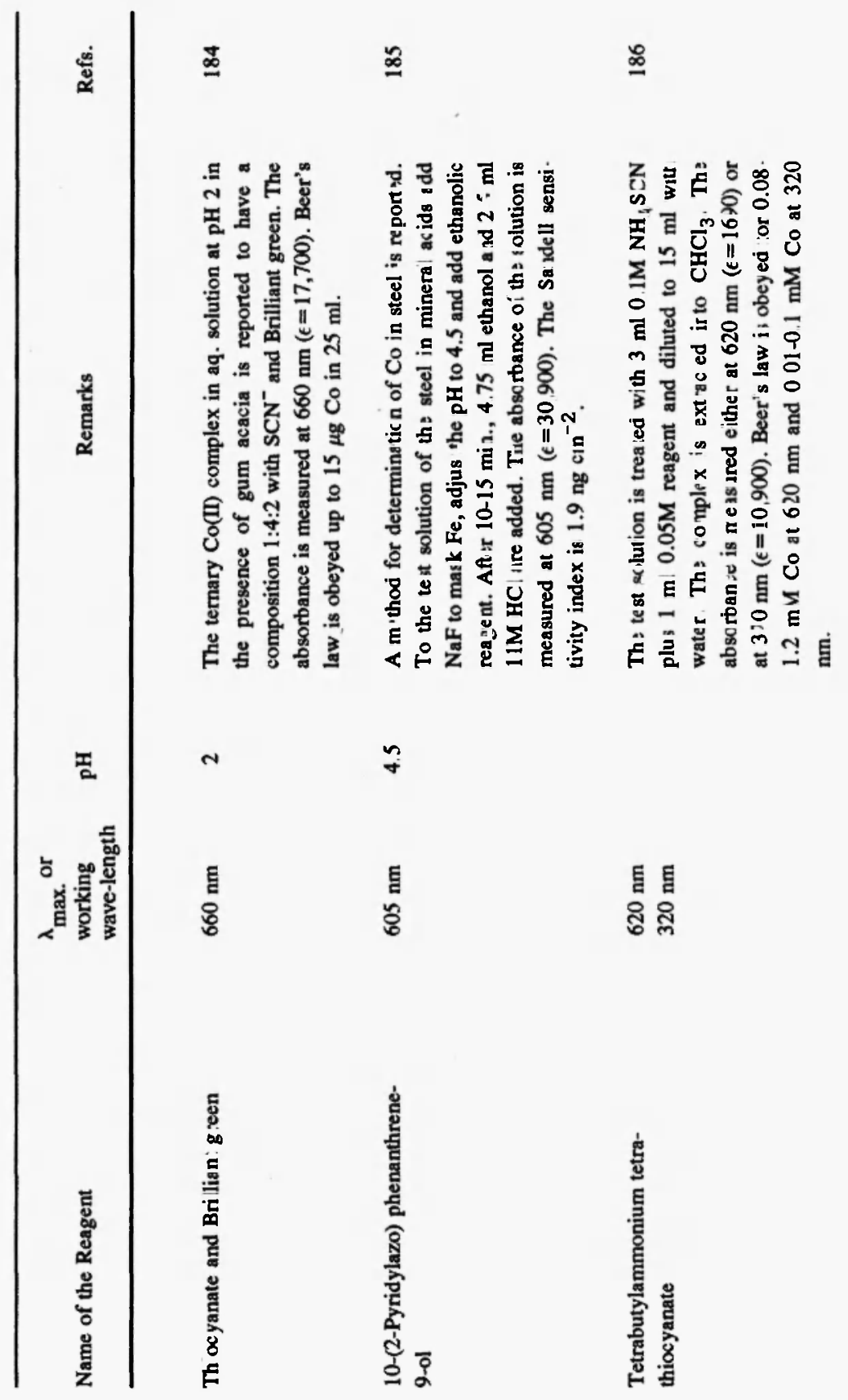




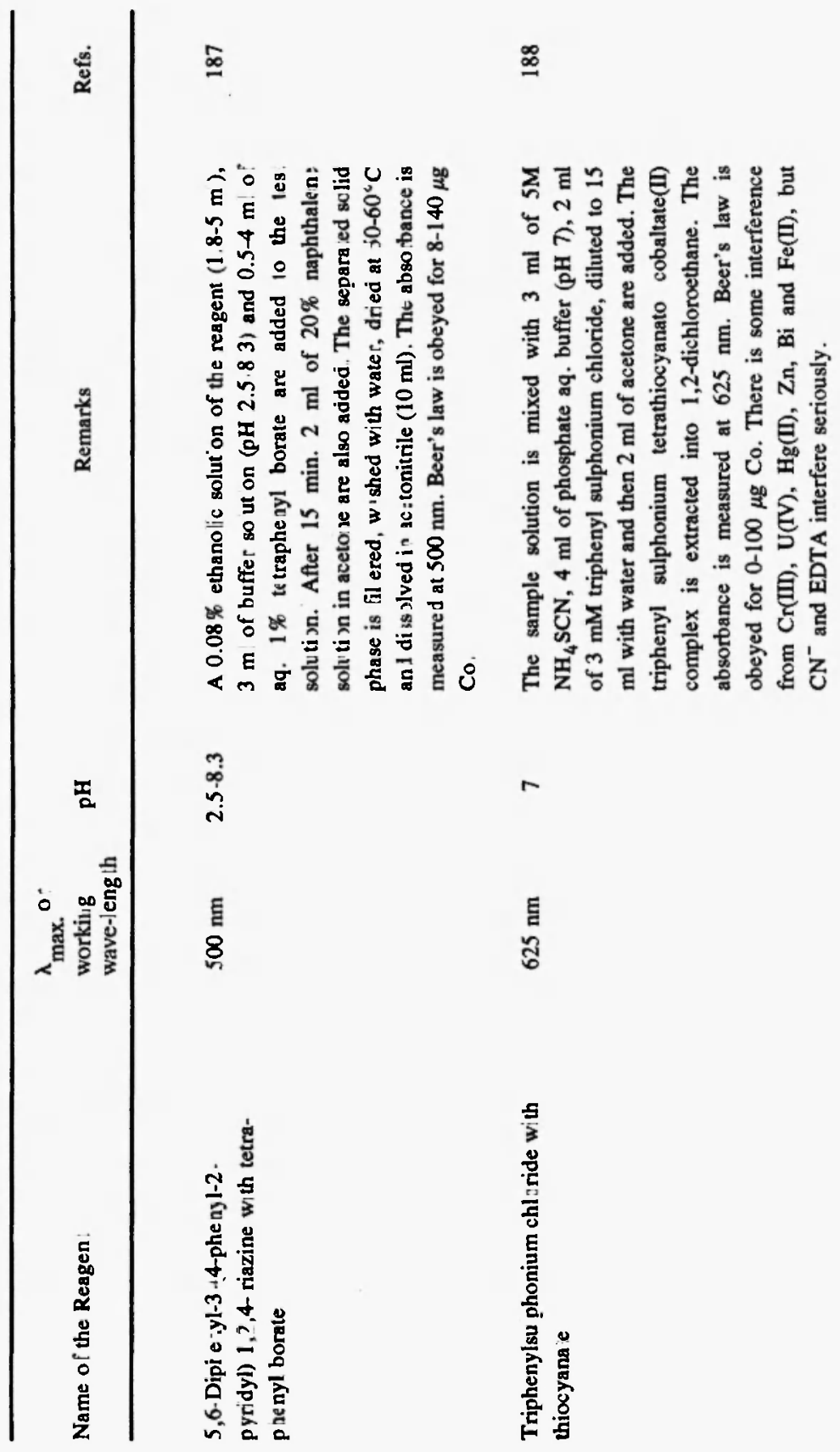




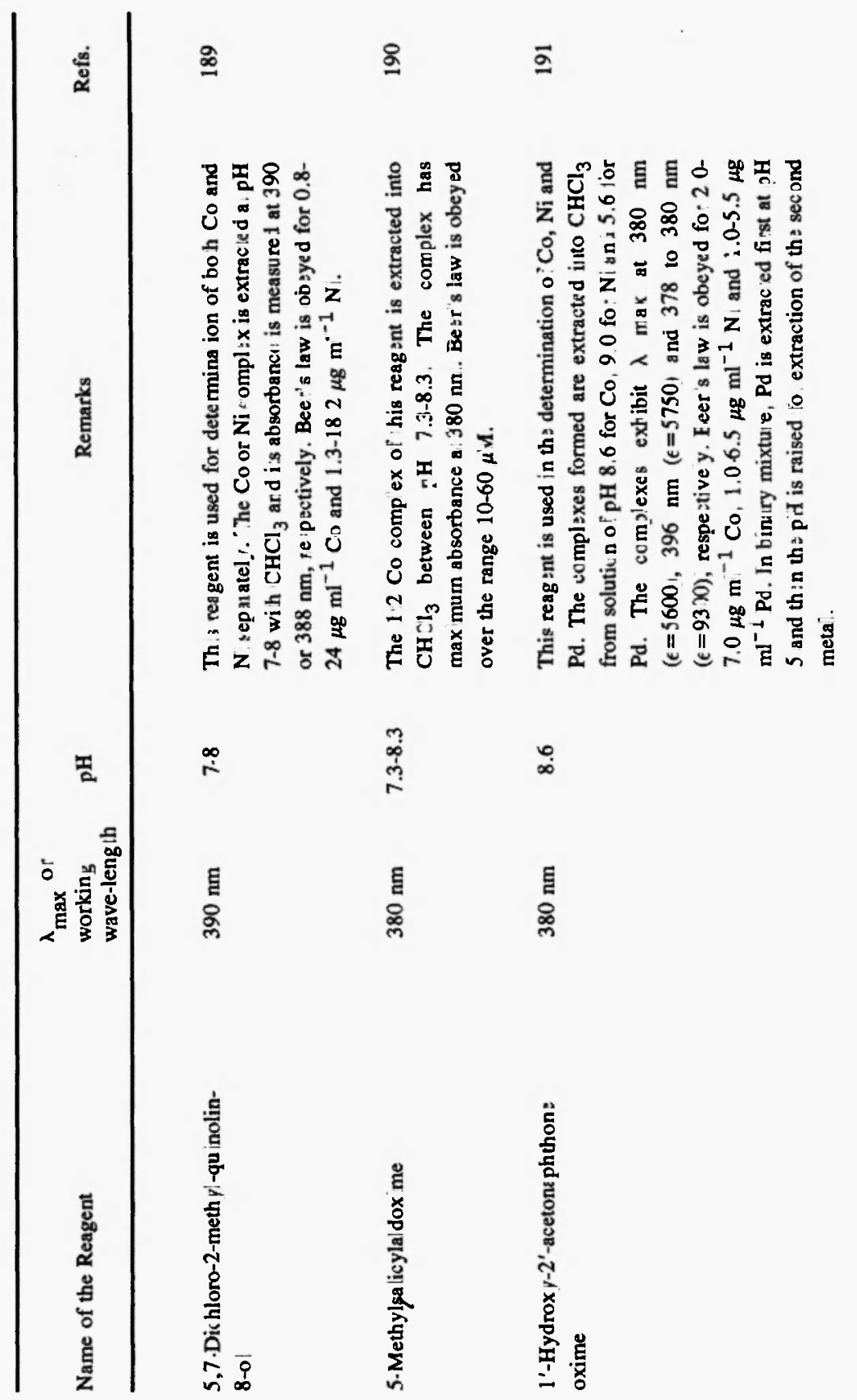




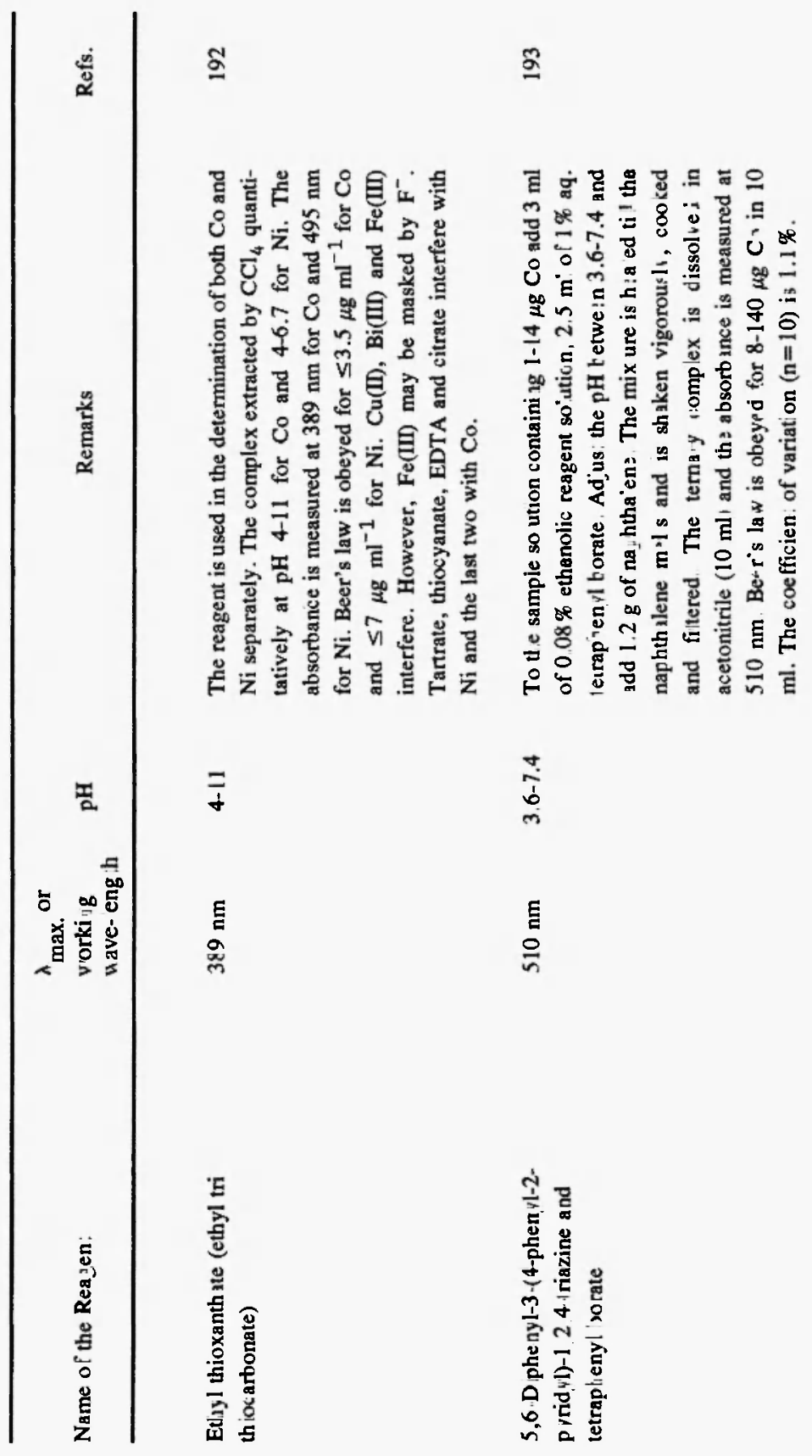




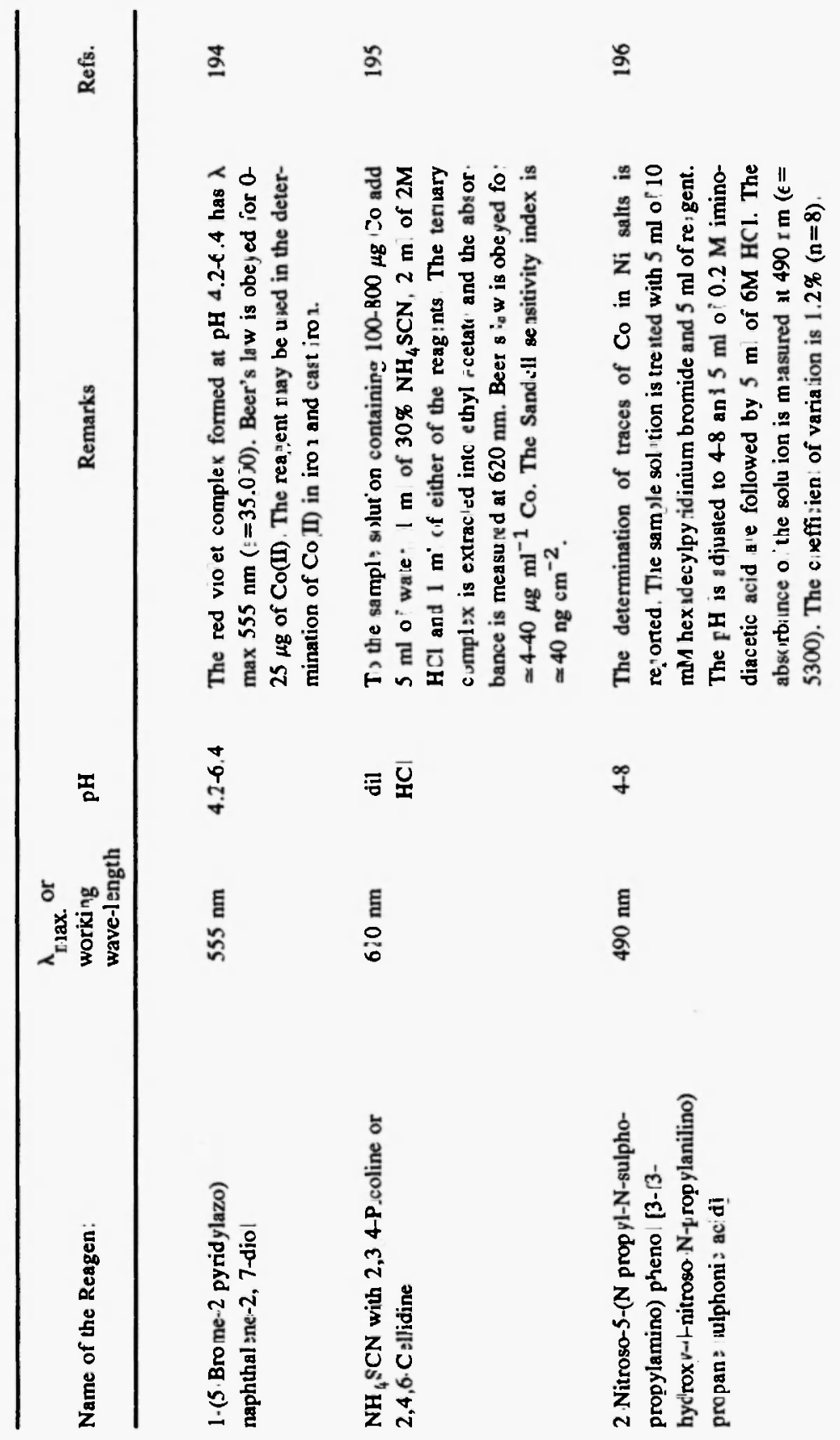




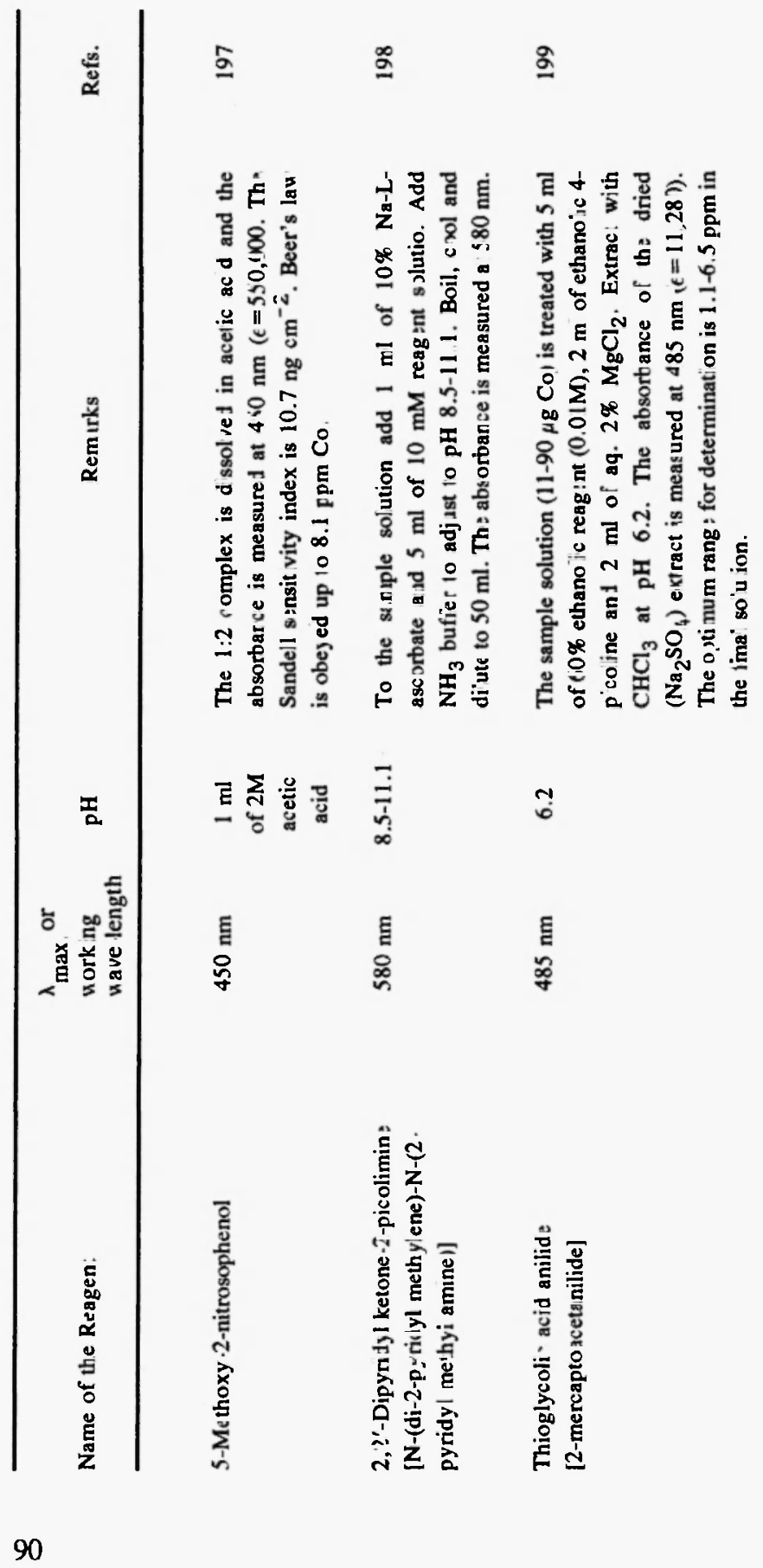




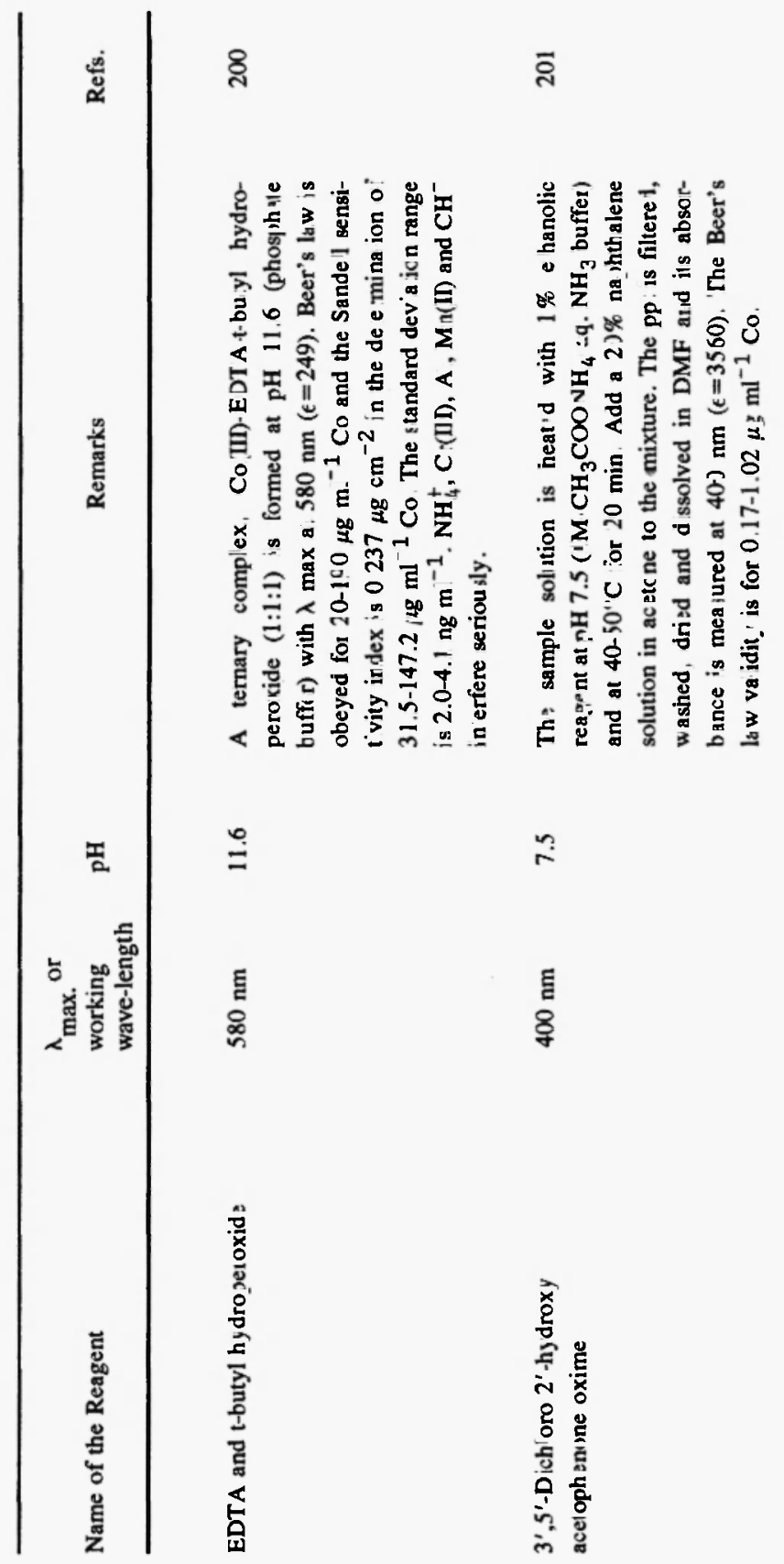




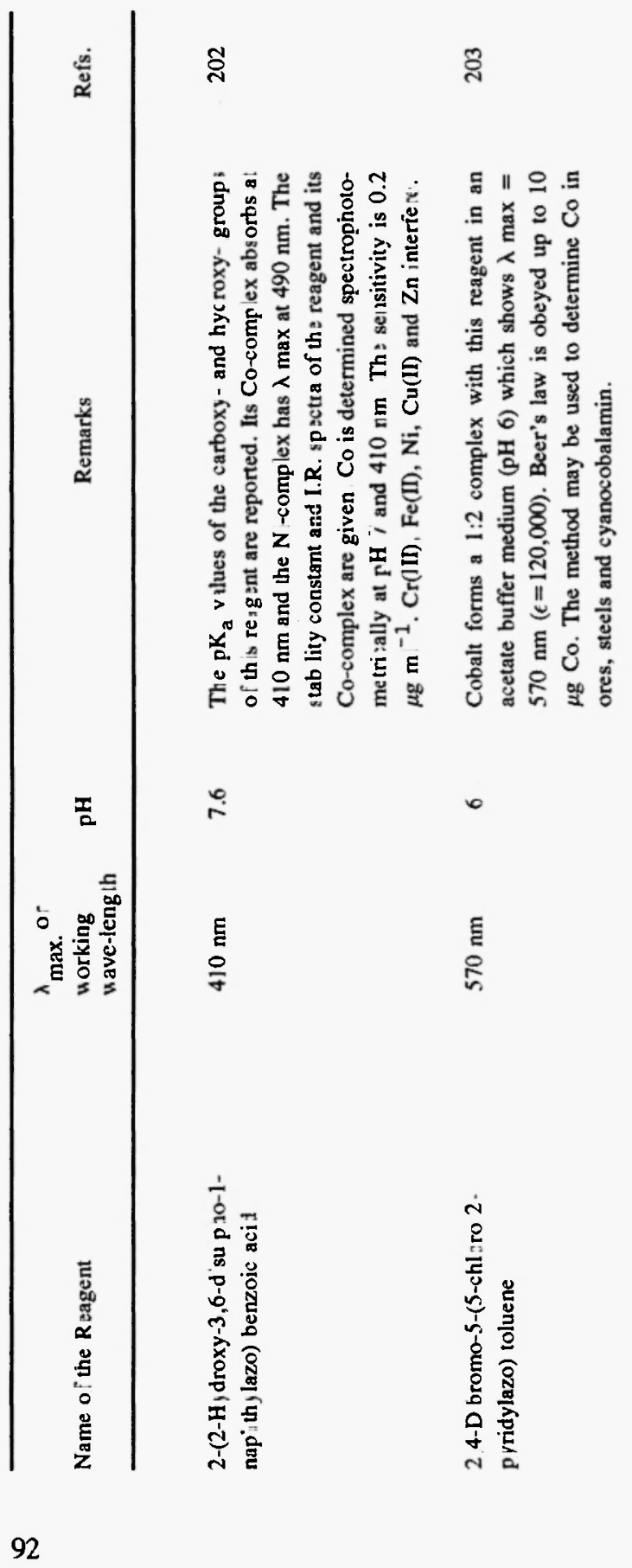




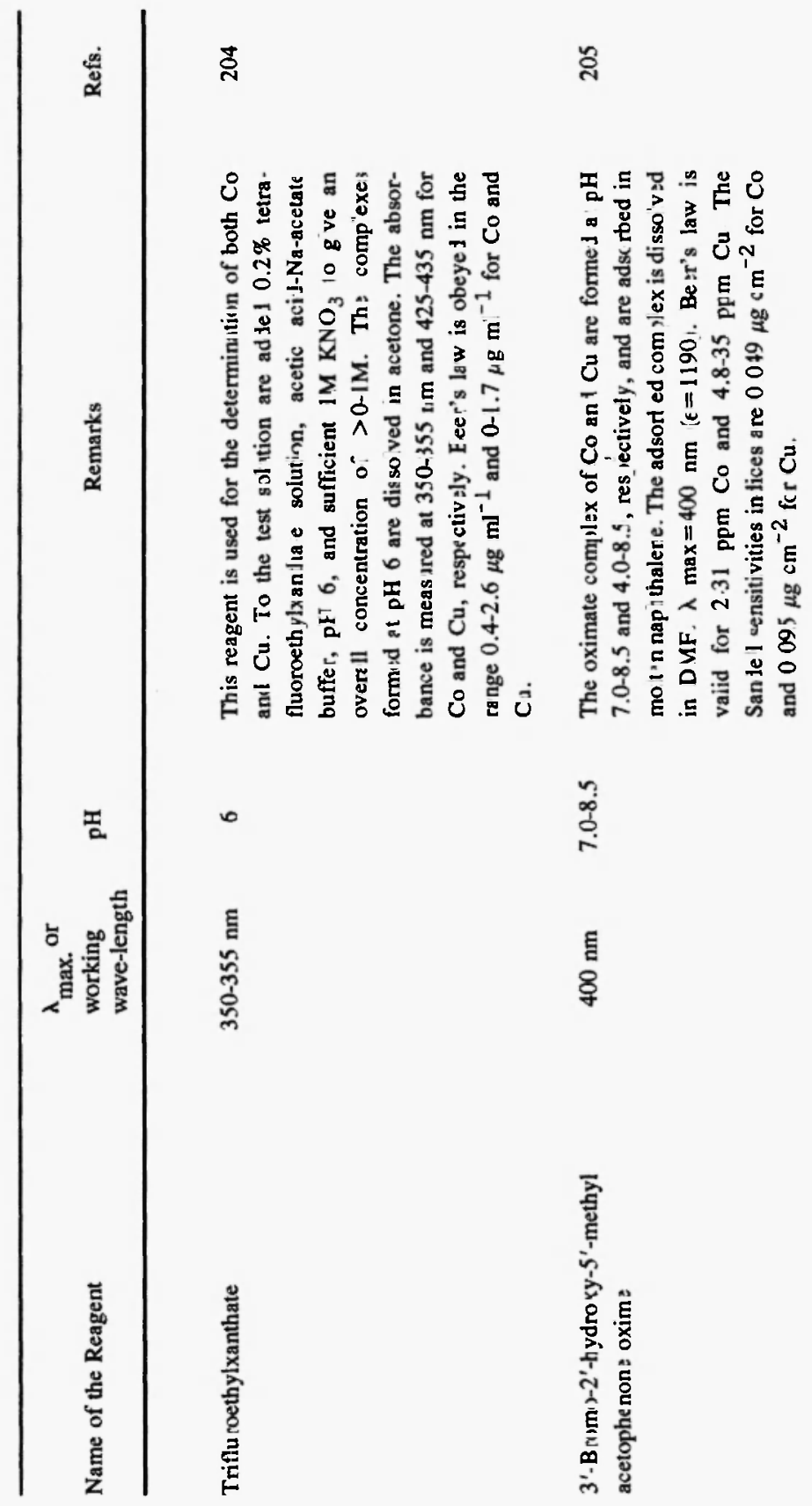




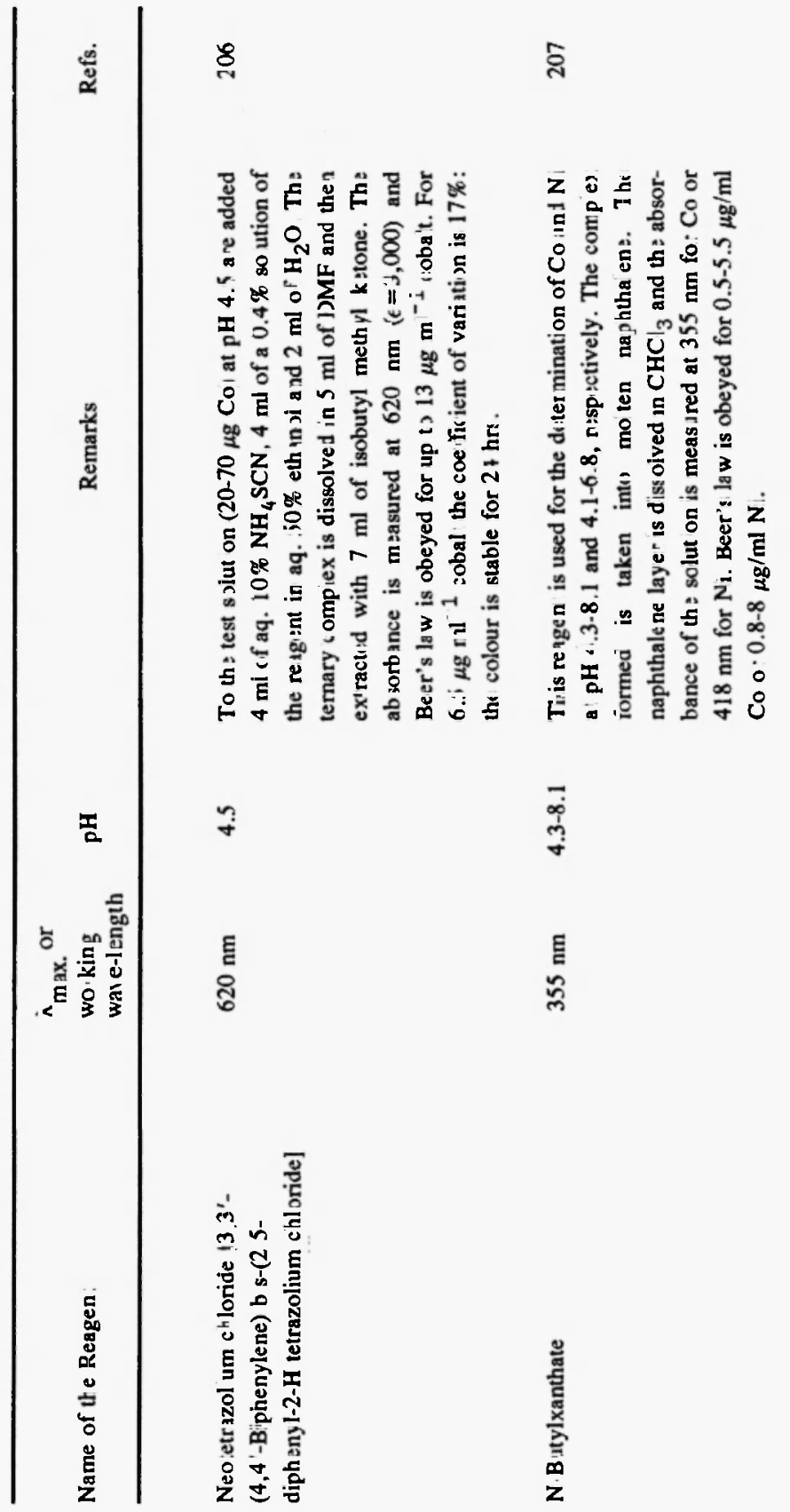




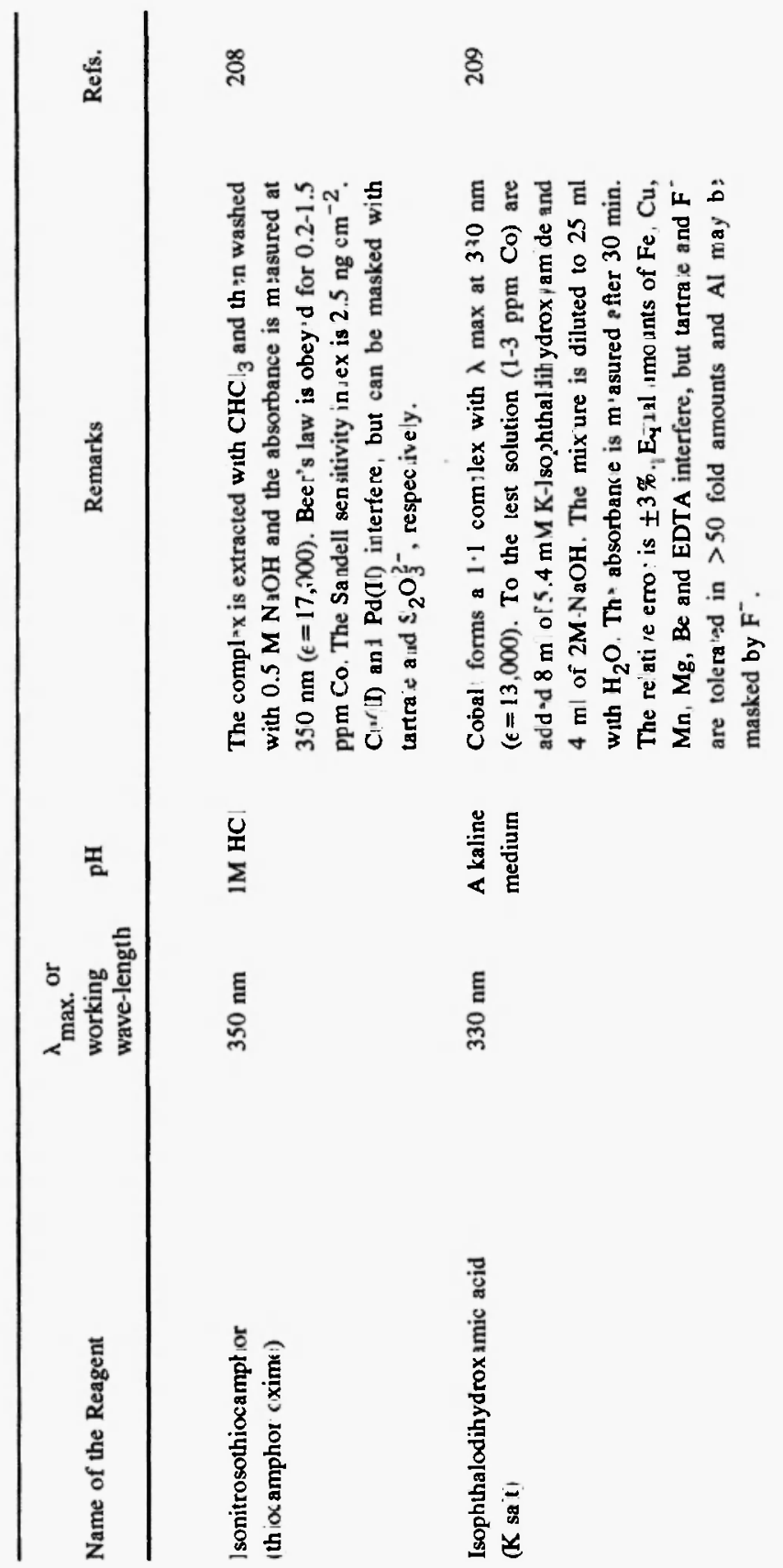




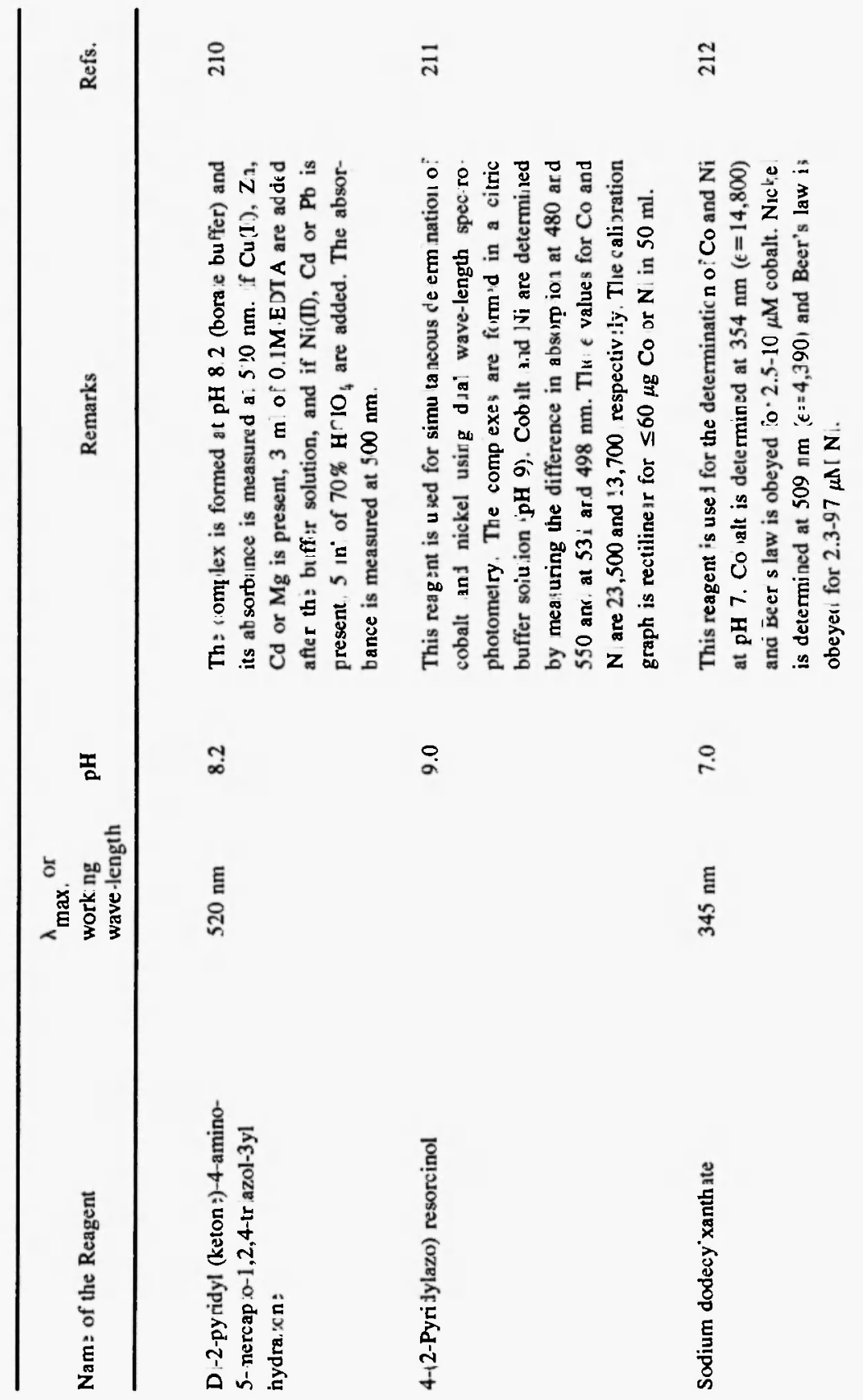




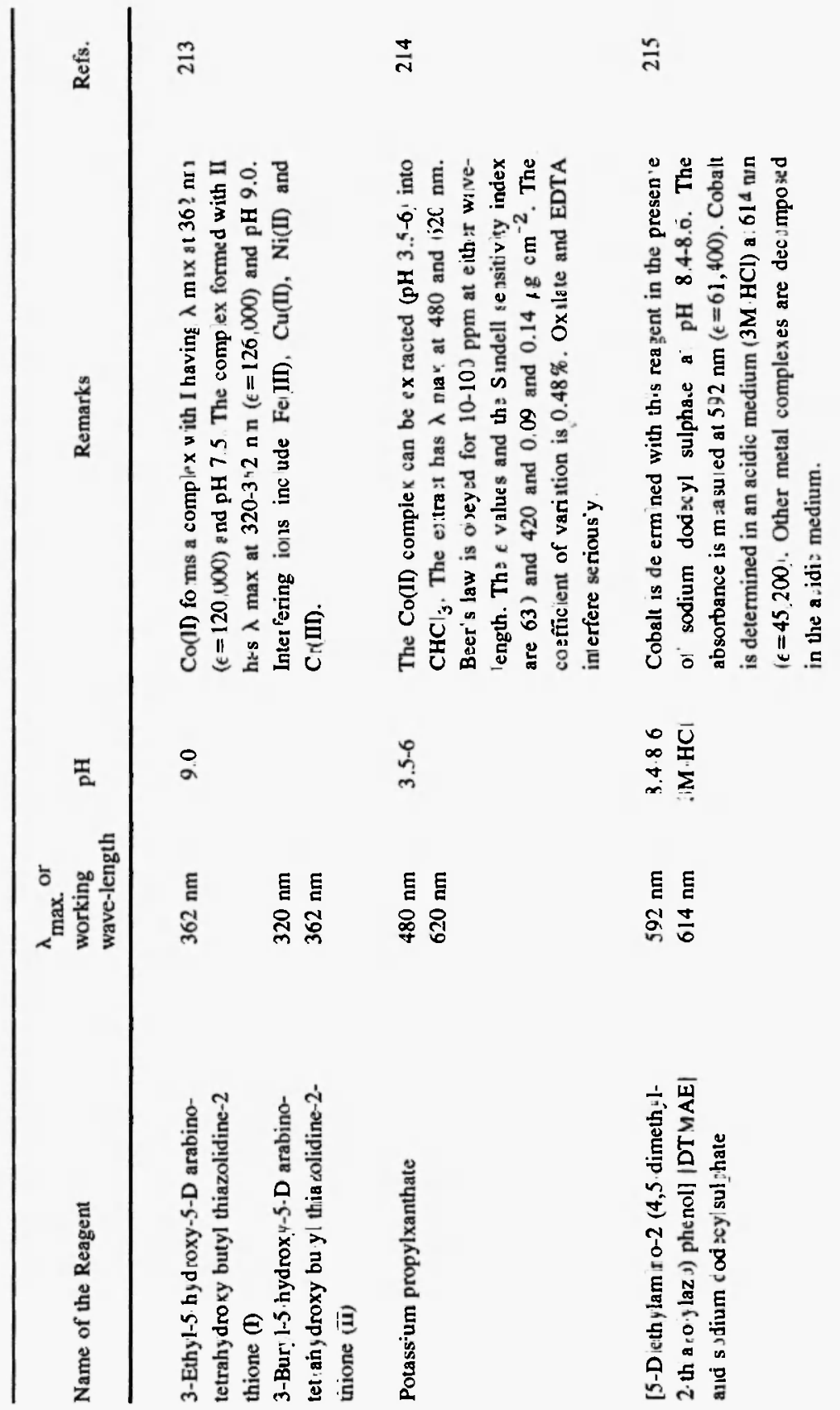




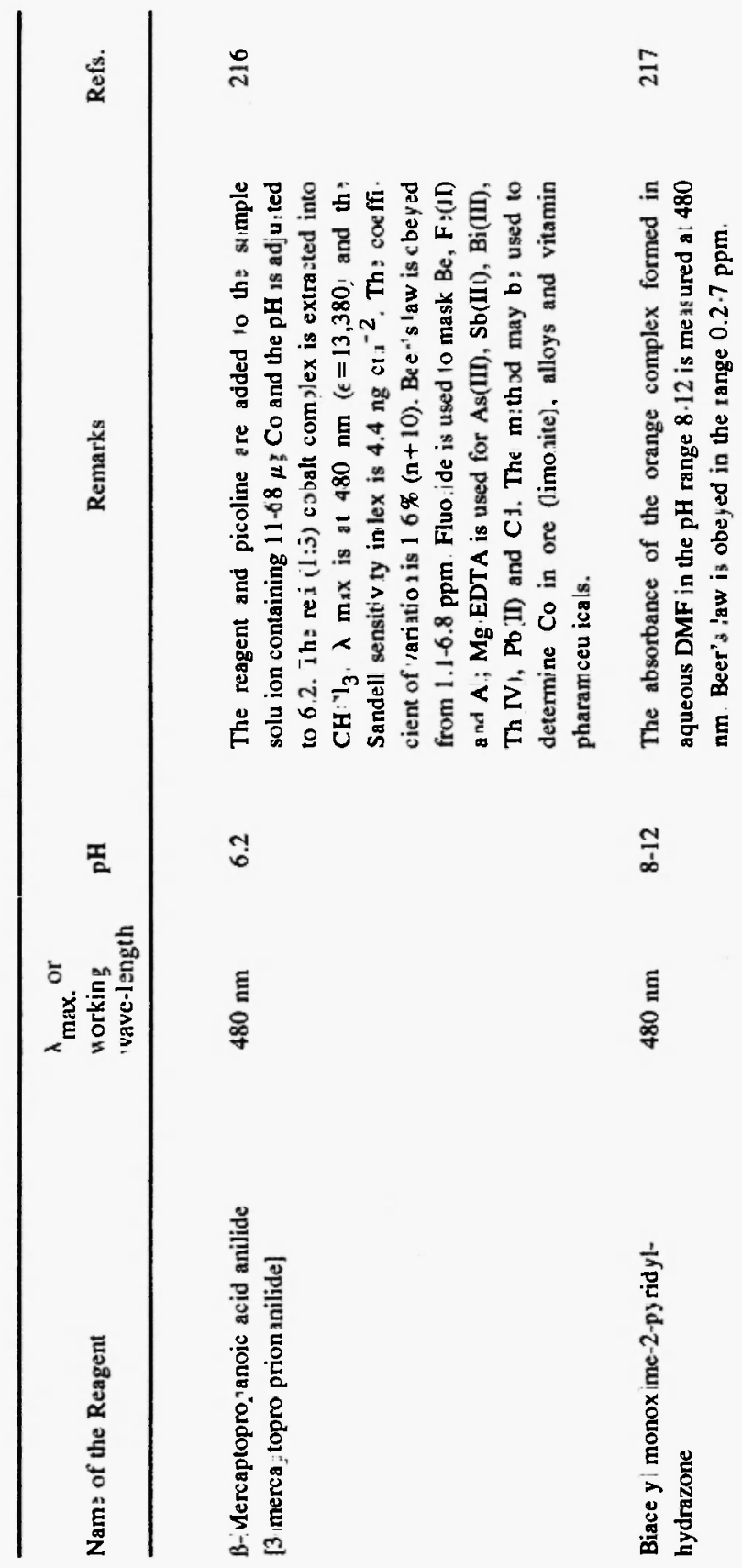




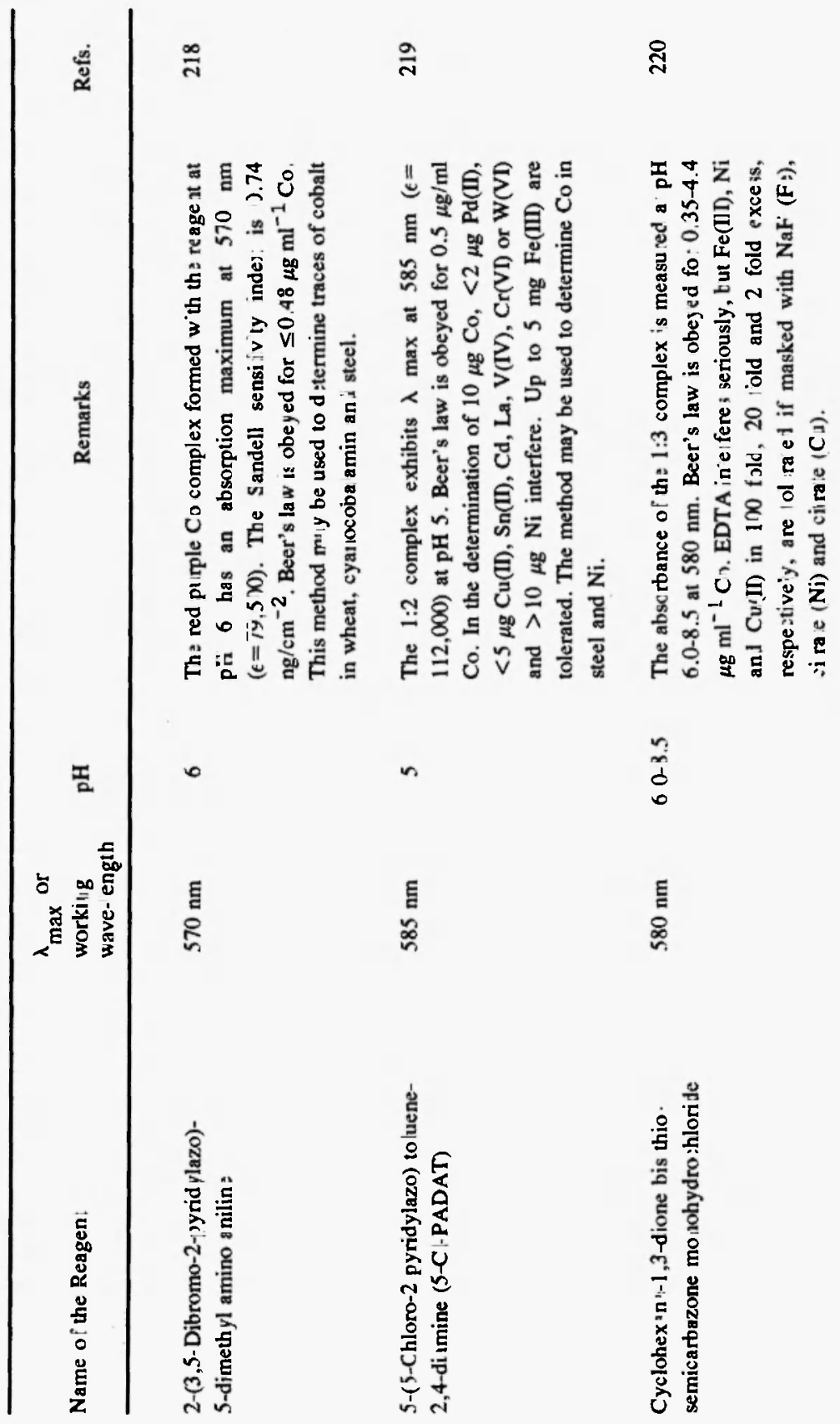




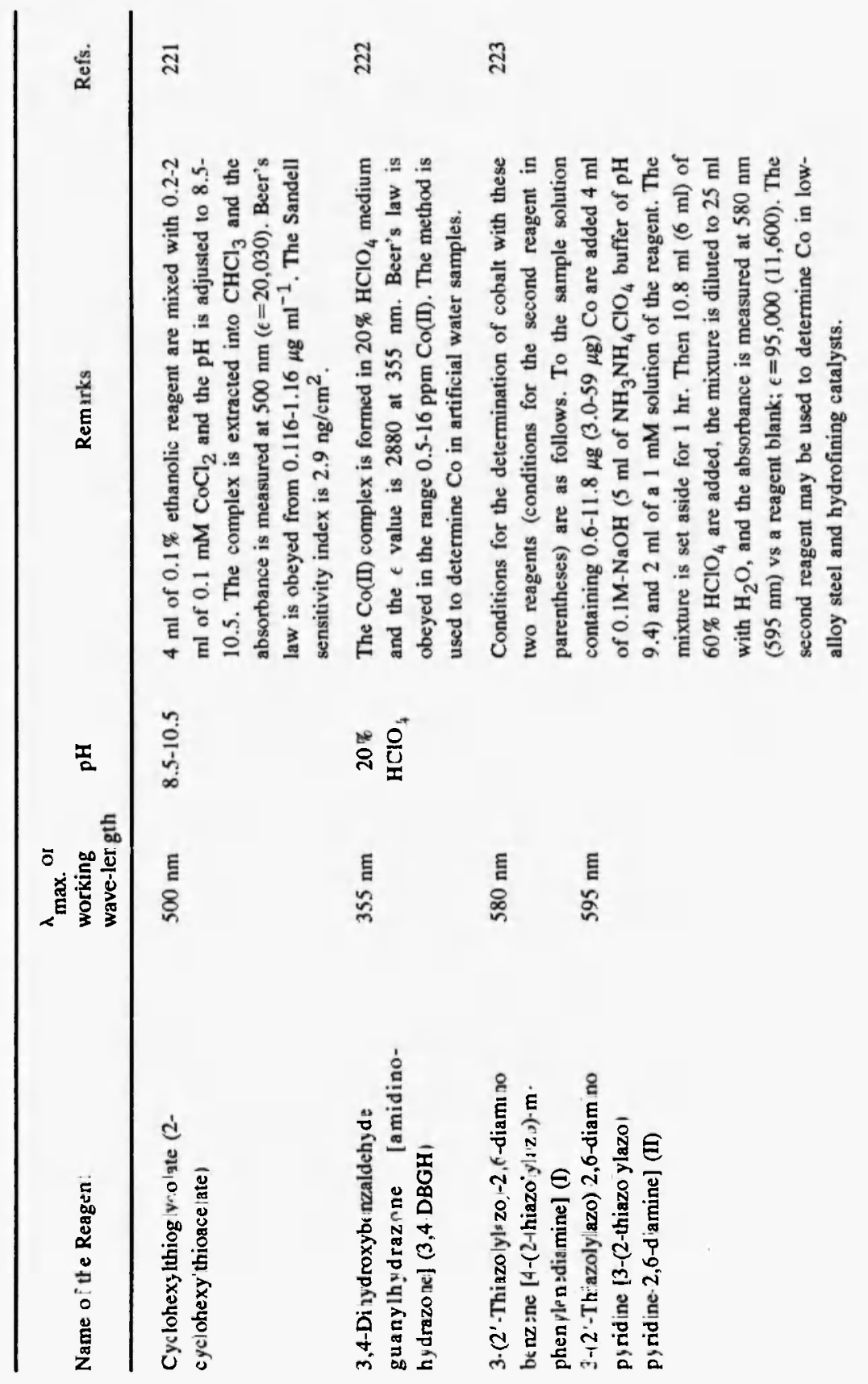




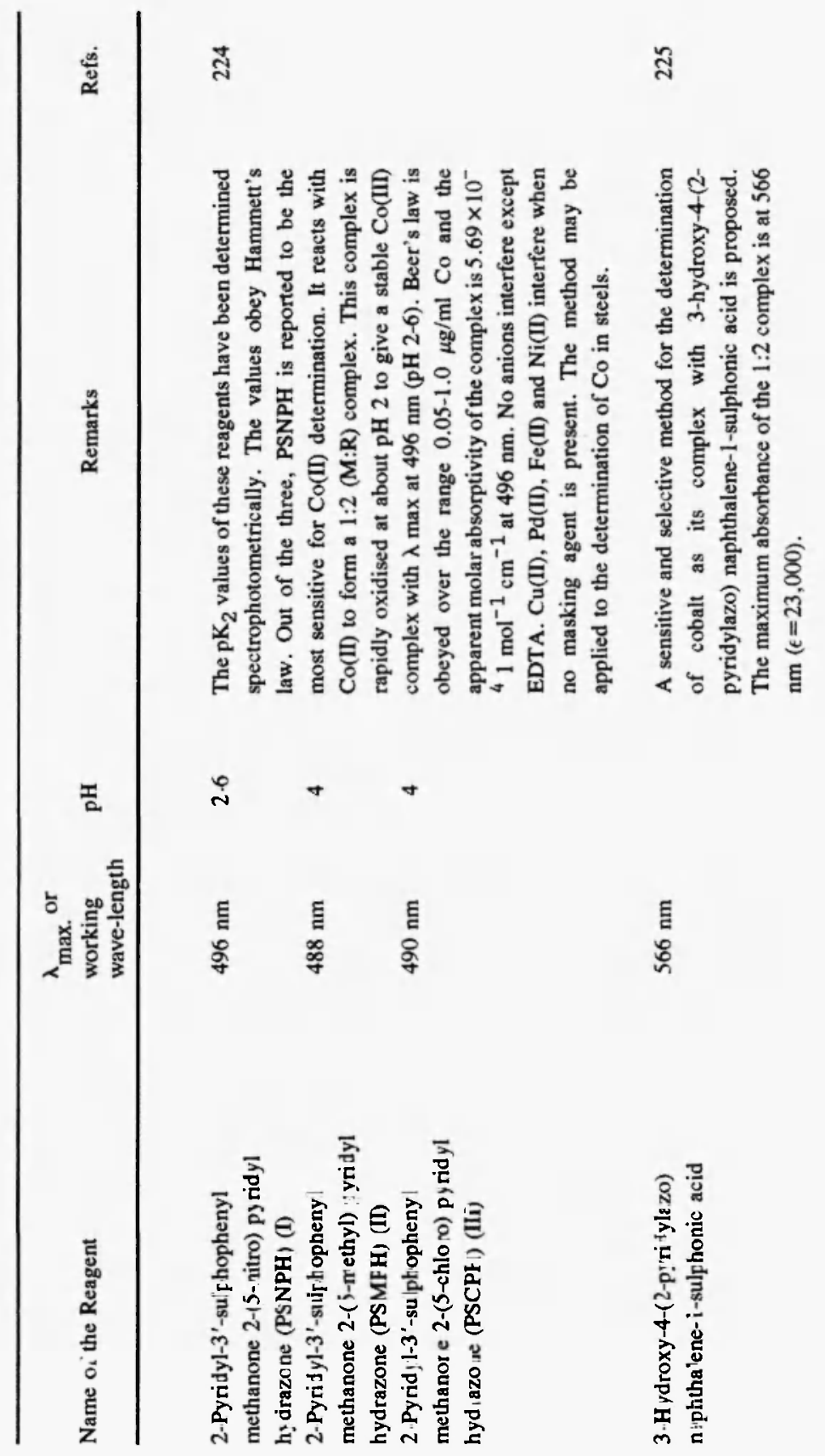




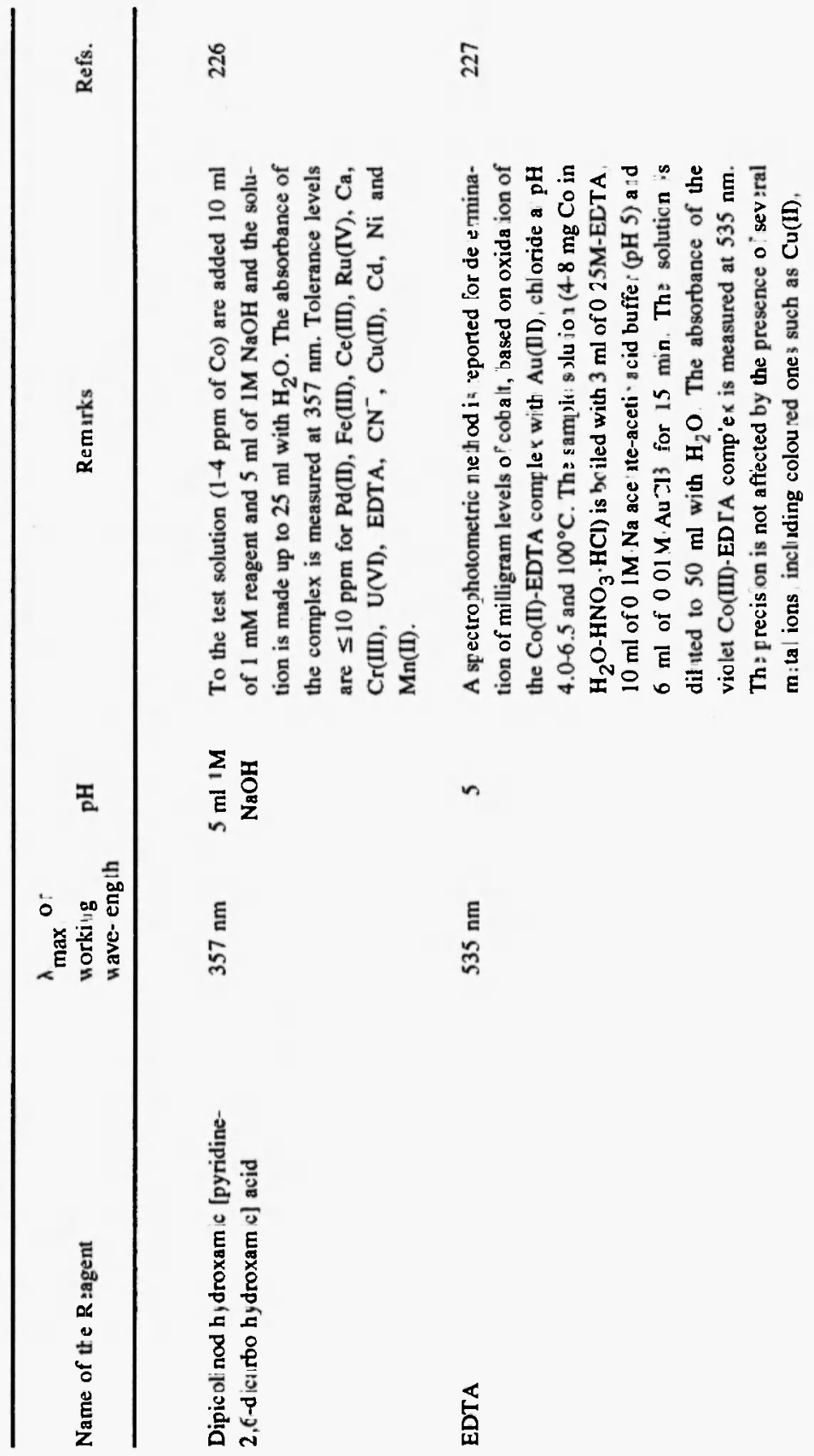




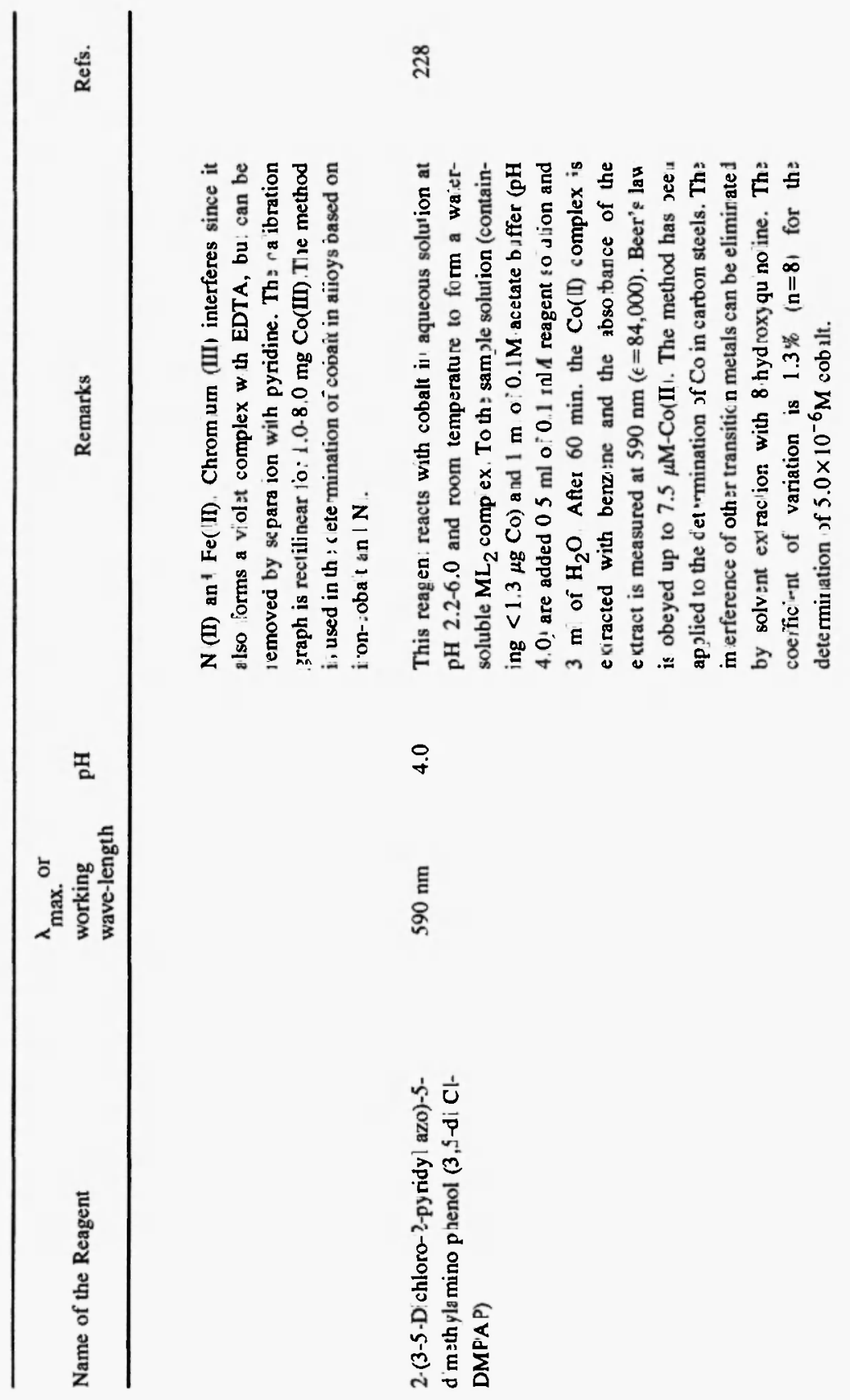


This survey of the literature reveals that a large number of reagent and methods have been reported for the spectrophotometric determination of cobalt. However, only a few hydroxytriazenes have been reported so far in this connection. In particular, the reagents of this series are gaining importance because of their ease of preparation and low cost of production and also because of their superiority in the determination of various metal ions. 


\section{REFERENCES}

1. E.A. Bashirov and A.M. Ayubova, Uchen. Zap. azerb. gos. Univ., Ser. Khim. Nauk, 3, 24 (1971); Referat. Zh. Khim., 19GD, 10 (1972), Abstr. No. $10 \mathrm{G} 86$.

2. E.A. Bashirov and A.M. Ayubova, Uchen. Zap. azerb. gos. Univ., Ser. Khim. Nauk, 4, 28 (1971); Referat. Zh. Khim., 19GD, 11 (1972), Abstr. No. 11G134.

3. M.M.L. Khosla and S.P. Rao, Microchem. J., 17, 338 (1972).

4. L.V. Evshova, Zav. Lab., 38, 905 (1972).

5. W. Gorski and S. Podlasin-Paradowska, Acta Pol. Pham., 29, 31 (1972).

6. S. Motomizu, Analyst (London), 97, 986 (1972).

7. D. Nanova and B. Evtimova, Analyt. Chim. Acta, 62, 456 (1972).

8. M.B. Shustova and V.A. Nazarenko, Zav. Lab., 39, 18 (1973).

9. N.A. Batasheva, O.V. Sivonava and N.N. Gritsienko, Zav. Lab., 39, 17 (1973).

10. J. Mohmed, J. Mirjehan and H. Gilbert Ayres, Analyt. Chem., 44, 2263 (1972).

11. A.K. Rishi, B.S. Garg and R.P. Singh, Indian J. Chem., 10, 1037 (1972).

12. R.N. Virmani, B.S. Garg and R.P. Singh, J. Prakt. Chem., 314, 965 (1972).

13. E. Uhlemann and B. Schuknecht, Analyt. Chim. Acta, 63, 236 (1973).

14. R.R. Mulye and S.M. Khopkar, Mikrochim. Acta, 1973 (I), 55.

15. H.R. Notenboom, W.J. Holland and R.G. Billinghurst, Mikrochim. Acta, 1973 (III), 467.

16. S. Shibate, M. Furukawa and K. Gots, Talanta, 20, 426 (1973).

17. J. Dunach and F. Buscarons, Analusis, 2, 510 (1973).

18. T. Kuroha, Japan Analyst., 20, 1565 (1973).

19. E.L. Krukovaskya, S.T. Talipov, L.M. Zhabitskaya and J. Lobanova, Zh. Analit. Khim., 27, 2427 (1972).

20. I.M. Issa and M.M. Aly, Z. analyt. Chem., 266, 127 (1973).

21. M.P. Martinez Martinez, D. Perez Bendito and F. Pino Perez, Ann. Quim., 69, 747 (1973).

22. G.S. Vasilikiot is and T.A. Kouimtzis, Microchem. J., 18, 85 (1973).

23. I.V. Pyatnitskii and G.N. Trochinoskaya, Zh. Analit. Khim.,, 28, 704 (1973).

24. J.N. Srivastava and R.P. Singh, Talanta, 20, 1210 (1973).

25. E. Casassas, J.J. Arias and A. Mederos, Ann. Quim., 69, 1121 (1973). 
26. W.J. Holland, M. Depooter and J. Bozic, Mikrochim. Acta, 1974 (I), 99.

27. K. Manolov and N. Motekov, Mikrochim. Acta, 1972 (II), 231.

28. R. Belcher, S.A. Ghonaim and A. Townshend, Talanta, 21, 191 (1974).

29. A. Garciade Torres, M. Valcarcel and F. Pino Perez, Analyt. Chim. Acta, 68, 466 (1974).

30. L.I. Chernomorchenko, T.V. Chuiko and A.G. Akhmetshin, Zh. analit. Khim., 27, 2262 (1972).

31. S. Shibata and M. Furukawa, Japan Analyst, 22, 1077 (1973).

32. G.S. Vasilikiotis, T. Kouimtzis, C. Apostolopoulou and A. Voulgaropoulos, Analyt. Chim Acta, 70, 319 (1974).

33. S.T. Talipov, N.G. Smaglyuk and A. Khodzhav, Referat. Zh. Khim., 19GD, 1973(20), Abstr. No. 20G69; Anal. Abstr, 28, B-170 (1975).

34. N. Ohta, S. Tama, H. Nunokawa and H. Terai, Japan Analyst, 23, 931 (1974).

35. S.A. Dyachenko, S.O. Gerasimova, I.A. Belen'kaya and V.G. Pesen, Zh. analit. Khim., 29, 877 (1974).

36. K. Ohira, Y. Kidani and H. Koike, Japan Analyst, 23, 658 (1974).

37. Yu. A. Mittsel and A.V. Vasilev, Zh. analit. Khim., 29, 596 (1974).

38. A.R. Saple and D.N. Patkar, J. Indian Chem. Soc., 51, 738 (1974).

39. L.V. Ershova, V.H. Ivanov and A.I. Busev, Zh. analit. Khim., 29,1367 (1974).

40. Yu. M. Dedkov, T. Ya. Kalenchenko, A.S. Grzhegorzhevskii, $Z h$. analit. Khim., 29, 1374 (1974).

41. H. Gorniak and B. Jamk, Z. analyt. Chem., 273, 127 (1975).

42. M. Israilov, Yu. M. Yusupov, D.N. Pachadzhanov and Kh. Dadzhanov, Manuscript No. 1360-74 at INTI, Moscow, 1974, 10 pp; Anal. Abstr., 29, 4B211(313) (1975).

43. M. Rueda Rueda and J.A. Munozhieva, Quim. analyt., 29, 122 (1975).

44. N. Kh. Makusdov, Z.B. Nasyrova and S.N. Khosolapova, Zh. analit. Khim., 29, 2063 (1974).

45. D. Molch, H. Koening and E. Than, Z. Chemie. Lpz, 15, 410 (1975).

46. F. Kai and H. Egoshi, Analyt. Lett., 8, 575 (1975).

47. C.K. Bhaskare and S.K. Deshmukh, Z. analyt. Chem., 277, 127 (1975).

48. K. Lal and S.P. Gupta, Indian J. Chem., 13, 973 (1975).

49. H. Tomica-Sikorska, Chem. Analit., 20, 1025 (1975).

50. E.D. Korotkaya, A. Kh. Kilbus, V.E. Pochinok and T.S. Shulgach, Izv. Vyssh. Ucheb Zaved. Khim. Khim. Tekhnol, 18, 1695 (1975). 
51. M.P. Martinez, M. Valcarcel and F. Pino Perez, Analyt. Chim. Acta, 81, 157 (1976).

52. K. De and J. Das, J. Indian Chem. Soc., 52, 1026 (1975).

53. C.K. Bhaskare and V.D. Jagadale, Z. analyt. Chem., 278, 127 (1976).

54. S.B. Savin, T.V. Tetrova and T.G. Dzherayan, Zh. analit. Khim., 30, 2092 (1975).

55. P.R. Haddad, P.W. Alexander and L.E. Smythe, Talanta, 23, 275 (1976).

56. K.N. Bagdasarov, M.S. Chernov'yants, T.M. Chernoivanova and E.G. Tsupak, Zav. Lab., 42, 143 (1976).

57. A.K. Singh, M. Katyal and R. P. Singh, Ann. Chim., 65, 109 (1975).

58. T.L. Radovskaya, Zav. Lab., 42, 398 (1976).

59. J.L. Gomez Ariza and J.M. Cano Pavon, Analyt. Lett., 9, 677 (1976).

60. H.L. Ray, B.S. Garg and R.P. Singh, J. Chin. Chem. Soc. (Taipei), 23, 47 (1976).

61. S. Shahine, M. Fathy Elshahat and S. Khamis, Microchem. J., 21, 279 (1976).

62. D.G. Gambarov, S.B. Bilalov and A.K. Babaev, Zh. analit. Khim., 31, 1731 (1976).

63. J.M. Cano Pavon, A. Lavado and F. Pino Perez, Mikrochim Acta , 1976 (II), 233.

64. M. Satake, M. Shimizu and Y. Nagaosa, Fukui Daigaku Kogakubu Kenkyu Hokoku, 24, 53 (1976).

65. S. A. Abbasi, B.G. Ghat and R.S. Singh, Z. analyt. Chem., 282, 222 (1976).

66. S. Musumeci, E. Rizzarelli, I. Fragala, S. Samaratano and R.P. Bonomo, Z. analyt. Chem., 282, 221 (1976).

67. F. Vlacil and A. Jehlickova, Coll. Czech. Chem. Comm., 41, 3749 (1976).

68. F. Garcia Montelogo and J.A. Lopez Cancio, Ann. Quim., 73, 248 (1977).

69. S. Motomizu and K. Toei, Analyt. Chim. Acta, 89, 167 (1977).

70. V.M. Peshkova, T.V. Polenova and Yu. A. Barabalat, $Z$ h. analit. Khim., 32, 471 (1977).

71. A.E. Mahgoub, A.S. Shawali and M.M. Shoukry, Z. analyt. Chem., 284, 205 (1977).

72. G. Popa and N. Dumitrescu, Rev. Chim. (Bucharest), 28, 486 (1977).

73. Ishwar Singh, B.S. Garg and R.P. Singh, Z. analyt. Chem., 284, 42 (1977).

74. E. Domaglina and S. Zareba, Farm. Pol., 33, 207 (1977). 
75. M.B. Saha and A.K. Chakraburtty, J. Indian Chem. Soc., 53, 1137 (1976).

76. M.A. Dosal Gomez and J.A. Perez-Bustamante, Ann. Quim., 73, 968 (1977).

77. N. Ahmad and C. Munir, Microchem. J., 22, 381 (1977).

78. M. Valcarcel, M.P. Martinez and F. Pino Perez, Quim. analit., 31, 75 (1977).

79. A.K. Singh, M. Katyal and R.P. Singh, J. Indian Chem. Soc., 53, 691 (1976).

80. C.P. Savariar and T.R. Hariharan, J. Indian Chem. Soc., 54, 274 (1977).

81. S.B. Ghosle, A.S. Ghormade and R.B. Kharat, J. Indian Chem. Soc., 53, 728 (1976).

82. T. Odashima and H. Ishii, Bunseki Kagaku, 26, 678 (1977).

83. V. Gonzalez Diaz, J.J. Arias and F. Garcia Montelongo, Ann. Quim., 73, 1300 (1977).

84. K. Watanabe, A. Fujiwara, M. Sakai and K. Kawagaki, Bunseki Kagaku, 26, 844 (1977).

85. C. K. Bhaskare and U.S. Jagadal, Analyt. Chim. Acta, 93, 335 (1977).

86. M.L. Tsap, Z.V. Proskura, N.S. Gedz and S.P. Sheredeko, Agrokhimiya, 120 (1977).

87. Yu.M. Dedkov, T.Ya. Kalenchenko and Yu.I. Usalinko, Izv. Vyssh. Uchebn. Zaved, Khim. Khim. Tekhnol., 21, 357 (1978).

88. N.P. Mukhovikova, M.I. Bulatov and V.F. Vushukova, Izv. Vyssh, Uchebn. Zaved, Khim. Khim. Tekhnol., 21, 510 (1978).

89. K. Kayashi, Y. Sasaki, S. Tagashira, K. Itoh and M. Sujuki, Bunseki Kagaku, 27, 204 (1978).

90. C. Marone and R. Olsina, Cron. Chim., 49, 10 (1977).

91. F. Jimenez Sierra and M. Cordoba Hernandez, Ann. Quim., 74, 261 (1978).

92. S.I. Gusev, V. Yu. Gusev, I.N. Glushkova, L.G. Zazhina, M.V. Zhuvakina, L.A. Ketova and I.A. Kozhevnikova, Zh. analit. Khim., 33, 734 (1978).

93. M.J. Presas Barrosa, F. Bermezo Martinez and J.A. Rodriguez Vazquiz, Bol. Soc. Quim. (Peru), 43, 26 (1977).

94. T. Ya. Kalenchenko, G.A. Butenko and Yu. M. Dedkov, Vopr. Khim. Khim. Tekhnol., 46, 78 (1977).

95. E. Wajda and B. Janik, Chem. Analit. (Warsaw), 23, 295 (1978).

96. M. Yoshio, M. Yugamura, H. Noguchi and M. Nagamastu, Analyt. Lett., 11, 281 (1978). 
97. A.O. Onov, Khim. Geol. Nauk., 4, 110 (1977).

98. P.W. Beaupre and W.J. Holland, Mikrochim. Acta, 1978 (II), 95.

99. J. Singh and S.P. Gupta, Acta Ciencia Indica, 3, 112 (1977).

100. P.W. Beaupre and W.J. Holland, Mikrochim. Acta, 1978 (II), 239.

101. C.K. Bhaskare, S.V. Kulkarni, K.N. Ganage and S. Devi. J. Indian Chem. Soc., 55, 199 (1978).

102. S.P. Mathur, R.S. Thakur, C.S. Bhandari and N.C. Sogani, Talanta, 25, 592 (1978).

103. K. Matsusaki, Yamaguchi Daigaku Kogakubu Kenkyu Hokobu, 28, 249 (1978).

104. K. Watanabe and K. Kowagaki, Bunseki Kagaku, 27, 467 (1978).

105. K. Nakashima, H. Hirahara and S. Akiyama, Bunseki Kagaku, 27, 529 (1978).

106. L.V. Evmakova and V.A. Petrova, Zh. analit. Khim., 34, 168 (1979).

107. F. Capitan Garcia, M. Roman Ceba and F. Garcia Sanchez, Rev. Univ. Ind. Santander. Invest., 8, 43 (1978).

108. R.B. Singh, P. Jain, B.S. Garg and R.P. Singh, Analyt. Chim. Acta, 104, 191 (1979).

109. S.f. Cham and O.W. Lau, Mikrochim. Acta, 1979 (I), 241.

110. D.G. Gombarov, Zh. analit. Khim., 39, 738 (1979).

111. K. Ueda, Bull. Chem. Soc. Japan , 52, 1215 (1979).

112. J.M. Grana Molares, C. Baluja Santos, A. Alvarez Devesa and F. Bermezo Martinez, Analusis, 7, 249 (1979).

113. H. Kulshreshtra, R.B. Singh and R.P. Singh, Analyst (London), 104, 572 (1979).

114. A.K. Panova, D.I. Bakurdzhieva and G.V. Angelova Dokl, Bolg. Akad. Nauk, 32, 461 (1979).

115. B.V. Rao, D. Venkteswara Rao and K.C. Sarojam, Indian J. Tech., 16, 336 (1978).

116. G. Bianchi, C. Bianchi and E. Gerlo, Afinidad, 35, 30 (1978).

117. Y. Rokugalva, M. Sugawara and T. Kambara, Bull. Chem. Soc. (Japan), 52, 2303 (1979).

118. R.B. Singh, H.L. Ray, B.S. Garg and R.P. Singh, Talanta, 26, 898 (1979).

119. M. Tsuchiya, Nippon Kayaku Kaishi, 5 , 597 (1979).

120. I. Singh, J.L. Sharma, B.S. Garg and R.P. Singh, J. Chin. Chem. Soc. (Taipei), 26, 121 (1979).

121. M.C. Mehra and D. Leblani, Microchem. J., 24, 435 (1979).

122. N.V. Popandopulo, V.K. Zlobin and T.N. Vladimirskaya, Metody Anal. Kontrolya Kach. Prod. Khim. Prom-sti., 6, 23 (1978). 
123. M.M. Khater, Y.M. Issa, A.F. Shouksy and F.A.A. El-Seify, Mikrochim. Acta, 1979 (II), 501.

124. U.K. Jetley, J. Singh and S.N. Rastogi, Acta Ciencia India, 5, 169 (1979).

125. A.G. Asuero and M.M. Rodriguez, Analyst (London), 105, 203 (1980).

126. J. Gimenner Plaza and J.D. Jimenez Gallardo, Afinidad, 36, 237 (1979).

127. N.R. Biswas, B.C. Ray and S. Lahiri, Indian J. Chem. Sec. A., 19, 58 (1980).

128. G. Popa and N. Dumitrescu, Ser. Chim. Metal, 40, 17 (1978).

129. D. Thorburn Burns and P. Hanprasopnattana, Analyt. Chim. Acta, 115, 389 (1980).

130. O.S. Chauhan, I. Singh, B.S. Garg and R.P. Singh, Ann. Chim. (Rome), 69, 363 (1979).

131. A.A. Elsirafy, Z. analyt. Chem., 301, 26 (1980).

132. B.K. Puri and M. Gautam, J. Chem. Tech. Biotechn, 30, 244 (1980).

133. F. Garcia Sanchez, F. Bosch Reig and J.M. Estela, Ann. Quim. Ser. B., 76, 273 (1980).

134. M.Yu. Yusupor, M.A. Israilov, D.N. Pachadzhanov and E.V. Panova, Zav. Lab., 46, 390 (1980).

135. K. Nakashima and S. Akiyama, Yakugaku Zasshi, 100, 515 (1980).

136. M. Satake and N. Yoshida, Fukui Daigaku, Kagakubu Kenkyu Hokuku, 27, 261 (1970).

137. F. Montelongo Garcia, C.R. Tallo Gonzalez and V. Gonzalez, Analyst (London), 105, 762 (1980).

138. P.G. Ramappa, H. Sanke Gowda and S. Manjappa, J. Indian Chem. Soc., 57, 304 (1980).

139. M.A. Matveets, S.D. Akhmetova and P.S. Shcherbov, $Z h$. analit. Khim., 35, 1640 (1980).

140. G. Ionescu, A. Duca and F. Matei, Mikrochim. Acta, 1980 (I), 329.

141. A. Gonzalez Portel, L. Pias Garcia, F. Bermezo Martinez and C. Baluja-Santos, Microchem. J., 25, 353 (1980).

142. N. Subba Rami Reddy and D. Venkata Reddy, Analyt. Chim. Acta, 120, 395 (1980).

143. O. Baudino and B. Carlos Marone, Analyt. Chim. Acta, 119, 393 (1980).

144. J.M. Fernandez Soles, A. Alvarez Devera, F. Bermezo Martinez and G. Manuela Gonzalez, Acta Quim. Compostelana, 3, 19 (1979).

145. M.S. Al-Obadie, J. Indian Chem. Soc., 57, 1059 (1980). 
146. A. Tyagi, R.P. Tyagi and B.C. Joshi, Afinidad, 37, 333 (1980).

147. A.K. Bhattacharjee and M.K. Mahanti, Indian J. Chem. Sec. A., 20, 427 (1981).

148. C. Laino, M. Carmen, L. Ferreira, R. Antonia and B. Martinez, Acta Quim. Compostelana, 3, 134 (1979).

149. M. Gautam, R.K. Bansal and B.K. Puri, Bull. Chem. Soc. Japan , 54, 3178 (1981).

150. J.J. Arias, M.L. Perez-Pont and F. Garcia Montelongo, Ann. Quim. Ser. $B, 77,353$ (1981).

151. S. Okawa, B. Kominami and A. Kawase, Bunseki Kagaku, 31, 373 (1982).

152. M. Furukawa, R. Nakashima, E. Kamta and Shozoshibata, Nagoya Kogyo Gizutsu Shikensho Hokoku, 30, 287 (1981).

153. F. Garcia Sanchez, A. Navas, J.J. Laserna and A. Arbaizar, Analyst (London), 107, 35 (1982).

154. S.K. Singh, M. Kamini and S.K. Sindhwani, J. Chin. Chem. Soc. (Taipei), 29, 131 (1982).

155. G. Asuero Agustin, D. Rosales and M.M. Rodriguez, Analyst (London), 107, 1065 (1982).

156. H. Wada, T. Ishizuki, G. Nakagawa, Analyt. Chim. Acta, 135, 333 (1982).

157. P.K. Govil and S.K. Benerji, Bull. Inst. Chem., Acad. Sin., 28, 93 (1981).

158. M.A. Israilov, M. Yu. Pachadzanov and D.N. Pachadzanov, Izv. Akad. Nauk Tadzh. SSR, Otd. Fix-Mat, Geol-Khim. Nauk, 1, 45 (1981).

159. B.K. Puri, C.L. Sethi and A. Kumar, J. Chin. Chem. Soc. (Taipei), 29, 173 (1982).

160. P. J. Cacho and C. Nerin de la Puerta, Afinidad, 39, 44 (1982).

161. D. Thorburn Burns, P. Hanprasapwatlana and B.P. Murphy, Analyt. Chim. Acta, 134, 397 (1982).

162. S. Okawa, B. Kominami and A. Kawase, Bunseki Kagaku, 31, 373 (1982).

163. M. Satake, B.K. Puri, J. C. Yuh and L.F. Chang, Fukui Daigaku Kogakubu Kenkyu Hokoku, 30, 63 (1982).

164. S.P. Mathur, V.P. Mehta and M. Hasan, Chem. Analit. (Wassaw), 26, 1081 (1981).

165. C.L. Sethi, A. Kumar, B.K. Puri and M. Satake, Analyst (London), 108, 528 (1983).

166. M.M. Tananaiko and G.A. Todradze, Ukr. Khim. Zh. (Russ. Ed.), 49, 391 (1983). 
167. J. Singh, K.N. Sharma, U.K. Jetly, S.K. Rastogi and G.S. Bhuee, Chem. Era, 18, 218 (1982).

168. J.J. Arias, F. Jimenez, A.I. Jimenez and F. Garcia Montelongo, Ann. Quim. Ser. B., 79, 248 (1983).

169. G. K. Mukherjee and J. Das, J. Indian Chem. Soc., 60, 70 (1983).

170. F.J. Barragan de la Rosa, J.L. Gomez Ariza and F. Pino Perez, Miknochim. Acta, 1983 (II), 455.

171. H.S. Gowda, K.N. Thimmaiah and S.M. Ahmed, Current Sci., 52, 636 (1983).

172. M.B. Saha and A.K. Chakraburtty, J. Indian Chem. Soc., 60, 176 (1983).

173. B.K. Deshmukh, Chem. Analit. (Warsaw), 28, 297 (1983).

174. M. Kamini, F. Kamil and S.K. Sindhwani, J. Indian Chem. Soc., 60, 388 (1983).

175. R.B. Singh, T. Odashima and H. Ishii, Analyst (London), 109, 43 (1984).

176. H.S. Gowda, K.N. Thimmaiah and S.M. Ahmed, Indian J. Chem. Sect. A., 22, 551 (1983).

177. C.H. Evans, Anal. Biochem., 135, 335 (1983).

178. D.T. Burns and S. Kheawpintong, Analyt. Chim. Acta, 156, 329 (1984).

179. X. Chen, R. Zhou, D. Wu and L. Dong, Nanjing Daxue Xuebao, Ziran Kexue, 1, 84 (1983).

180. S. Yamaguchi and K. Uesugi, Bunseki Kagaku, 33, 112 (1984).

181. S. Srinivasan and V. Seshagiri, Acta Ciencia Indica, 9, 97 (1983).

182. S.P. Bag and B. Bhattacharya, J. Indian Chem. Soc., 60, 596 (1983).

183. K. Huo, Fenxi Huaxue, 12, 558 (1984).

184. Y. He and D. Huang, Fenxi Huaxue, 12, 389 (1984).

185. M. Milla Gonzalez, M.P. Martinez Martinez and J.A. PerezBustamante, Ann. Quim. Ser. B., 80, 351 (1984).

186. J. Hernandez-Mendez, A. Alonso-Mateos and E.J. Martin Mateos, Microchem. J., 30, 12 (1984).

187. J.L. Lin, L.-F. Chang, M. Katyal and M. Satake, Z. analyt. Chem., 319, 308 (1984).

188. D.T. Burns and S. Kheawpintong, Analyt. Chim. Acta, 162, 437 (1984).

189. A. Izguierdo, R. Compano and E. Bars, Mikrochim. Acta, 1984 (II), 345 .

190. D. Ivanovic, R. Milosevic and D. Radulovic, Acta Pharm. Jugosl., 34, 163 (1984). 
191. K.V. Reddy and A. Paul, Indian J. Chem. Sect. A., 23, 790 (1984).

192. A.L.J. Rao and J. Shekhar, 30, 283 (1984).

193. J.L. Lin, J. Chin. Chem. Soc. (Taipei), 31, 395 (1984).

194. G. Yang, Y. Liu, Q. Wu and Z. Wei, Huaxue Shiji, 6, 347 (1984).

195. P. Chattopadhyay and S.K. Majumdar, J. Indian Chem. Soc., 61, 621 (1984).

196. I. Yoshida and K. Veno, Bunseki Kagaku, 34, 77 (1985).

197. N.F. Mody, J. Inst. Chem., 57, 6 (1985).

198. T. Kato and K. Kano, Bunseki Kagaku, 34, 36 (1985).

199. C. Ray and J. Das, Indian J. Chem. Sec. A., 24, 40 (1985).

200. P. Bermezo Barrera, J.F. Vazquez Gonzalez and F. Bermazo Martinez, Analyst (London), 110, 811 (1985).

201. M. Satake, S.R. Malhotra and K. Lal, Acta Ciencia Indica, 10, 242 (1984).

202. E. Stefancu and D. Stefancu, Rev. Chim. (Bukharest), 36, 863 (1985).

203. G. Zhang, Y. Wu, C. Li, Y. Jin and B. Liu, Fenxi Huaxue, 13, 618 (1985).

204. M.F. Hussain, B.K. Puri, R.K. Bansal and M. Satake, Mikrochim. Acta, 1985 (I), 227.

205. S. Malhotra and K. Lal, Oriental J. Chem., 1, 107 (1985).

206. A.K. Singh, D. Kumar and M. Katyal, Analyt. Chim. Acta, 172, 303 (1985).

207. B.K. Puri, A.K. Gupta, A.L.J. Rao and M. Satake, Chim. Acta Turc, 12, 245 (1984).

208. P.K. Paria and S.K. Majumdar, Indian J. Chem. Sect. A., 24, 989 (1985).

209. F. Salinas, M. Jimenez-Arrabal and I. Duran, Microchem. J., 33, 194 (1986).

210. C. Samara and T.A. Koumitzis, Microchem. J., 33, 255 (1986).

211. S. Lus and Z. Yang, Fenxi Huaxue, 14, 47 (1986).

212. K. Hayashi, Y. Sasaki, S. Tagashira and N. Mito, Bunseki Kagaku, 35, 413 (1986).

213. J.R. Castillo, A. Lopez, J.M. Mir, O. Valiente and A. Alvarez, Quim. analit. (Barcelona), 4, 360 (1985).

214. P.K. Paria and S.K. Majumdar, Indian J. Chem. Sec. A., 25, 103 (1986).

215. Y. Zheng and Y. Lui, Fenxi Shiyanshi, 5,7 (1986).

216. C. Ray and J. Das, J. Indian Chem. Soc., 63, 236 (1986).

217. M.J. Navas, A.G. Asuero and D. Rosales, Microchem. J., 33, 331 (1986). 
218. G. Zhang, C. Li, Y. Hu, M. An and Y. Fan, Fenxi Shiyanshi, 5, 13 (1986).

219. X. Qui, Y. Zhu and L. Zhang, Rev. Chim. (Bukharest), 37, 586 (1986).

220. K.H. Reddy and D.V. Reddy, Chim. Acta Turc., 13, 77 (1985).

221. A.L.J. Rao, U. Gupta and J.S. Sandhu, J. Inst. Chem. (India), 58, 171 (1986).

222. E. Kavlentis, Mikrochim. Acta, 1, 27 (1986).

223. V. Gonzalez, M.J. Sanchez and F. Garcia Montelongo, Quim. analit. (Barcelona), 5, 335 (1986).

224. T. Odashima, T. Kikuchi, W. Ohtani and H. Ishii, Analyst (London), 111, 1383 (1986).

225. Z. Zhou, Z. Liang and B. Hu, Fenxi Shiyanshi, 5, 31 (1986).

226. F. Salinas, R. Forteza and J.M. Esteda, Ann. Quim. Ser. B, 83, 109 (1987).

227. B.V. Rao, V.G.R. Menon and K.C. Sarojam, Talanta, 34, 367 (1987).

228. M. Nakamura, Y. Sakanshi, H. Chikushi, F. Kai, S. Sato, T. Sato and S. Uchikawa, Talanta, 34, 369 (1987). 